University of Louisville

ThinkIR: The University of Louisville's Institutional Repository

Electronic Theses and Dissertations

8-2011

\title{
Arsenic-induced developmental changes in the liver and adult cardiovascular disease.
}

Ntube Nini Olive Ngalame

University of Louisville

Follow this and additional works at: https://ir.library.louisville.edu/etd

\section{Recommended Citation}

Ngalame, Ntube Nini Olive, "Arsenic-induced developmental changes in the liver and adult cardiovascular disease." (2011). Electronic Theses and Dissertations. Paper 1055.

https://doi.org/10.18297/etd/1055

This Doctoral Dissertation is brought to you for free and open access by ThinkIR: The University of Louisville's Institutional Repository. It has been accepted for inclusion in Electronic Theses and Dissertations by an authorized administrator of ThinkIR: The University of Louisville's Institutional Repository. This title appears here courtesy of the author, who has retained all other copyrights. For more information, please contact thinkir@louisville.edu. 


\title{
ARSENIC-INDUCED DEVELOPMENTAL CHANGES IN \\ THE LIVER AND ADULT CARDIOVASCULAR DISEASE
}

\author{
By
}

Ntube Nini Olive Ngalame

B.S., University of Buea, Cameroon, 2002

M.S., Lund University, Sweden, 2005

M.S., University of Louisville, 2009

\begin{abstract}
A Dissertation
Submitted to the Graduate Faculty of the School of Medicine, University of Louisville in Partial Fulfillment of the Requirements for the Degree of
\end{abstract}

\author{
Doctor of Philosophy \\ Department of Pharmacology and Toxicology \\ University of Louisville \\ Louisville, Kentucky
}

August 2011 

ARSENIC-INDUCED DEVELOPMENTAL CHANGES IN

THE LIVER AND ADULT CARDIOVASCULAR DISEASE

By

Ntube Nini Olive Ngalame

B.S., University of Buea, Cameroon, 2002

M.S., Lund University, Sweden, 2005

M.S., University of Louisville, 2009

A Dissertation Approved on

July 28, 2011

by the following Dissertation Committee:

J. Christopher States, Ph.D.

Gavin E. Arteel, Ph.D.

Sanjay Srivastava, Ph.D.

Aruni Bhatnagar, Ph.D.

Y. James Kang, Ph.D. 


\section{DEDICATION}

This Dissertation is dedicated to my husband, Mr. Ngome Llewellyn Makia, for all his love and support.

To my parents, Mr. Ngalame Paulinus Leo (of blessed memory)

and

Mrs. Ngalame Dione Bertha

who have given me invaluable educational opportunities, and unconditional love and support throughout my life. 


\section{ACKNOWLEDGMENTS}

I would like to thank my mentor, Dr. Christopher States, for his guidance, support and patience. I would also like to thank our collaborators and members of my committee, Drs. Gavin E. Arteel and Sanjay Srivastava, for their comments and assistance over the past four years. I would also like to thank other members of my committee, Drs. Aruni Bhatnagar and Y. James Kang, for serving on my dissertation committee for the past two years. I would also like to thank Dave Young for his technical asistance.

Last but not least, I would like to express my thanks to my husband, Ngome Makia, for his understanding, patience and encouragement, especially during times when nothing seemed to work right. Finally, I would also like to thank my daughter, Kayla Makia, for those warm and emotional smiles and hugs on days when I felt so discouraged. 


\section{ABSTRACT \\ ARSENIC-INDUCED DEVELOPMENTAL CHANGES IN THE LIVER AND ADULT CARDIOVASCULAR DISEASE}

Ntube Nini Olive Ngalame

July 28,2011

Chronic arsenic exposure is associated with increased cardiovascular disease (CVD). Prenatal arsenic exposure at $49 \mathrm{ppm}$ arsenic accelerates atherosclerosis underlying CVD in $\mathrm{ApoE}^{-/-}$mice, but the mechanism is unknown. This dissertation examines the mechanisms by which prenatal arsenic exposure accelerates atherosclerosis. Arsenic is a hepatotoxicant, and liver disease increases atherosclerosis risk. I hypothesized that prenatal arsenic exposure alters liver development and primes the liver for susceptibility to other environmental insults, predisposing to liver disease and accelerated atherosclerosis in $\mathrm{ApoE}^{-1-}$ mice.

I showed that prenatal arsenic exposure caused subtle but significant liver damage in 10 and 24 week old $A p o E^{-/}$mice, thus increasing the risk of atherosclerosis. This arsenic-induced liver injury was characterized by increased basal levels of plasma ALT and AST (circulating markers of liver damage), and IL-6 (pro-inflammatory cytokine).

Determination of the effects of prenatal arsenic exposure on Hsp70 and Hsc70 expression during pre- and postnatal development (GD18, and 3, 10 and 24 weeks) showed that Hsp70 was induced at age 3 and 10 weeks, but returned to 
unexposed levels by 24 weeks, thus indicating a temporal state of stress. However Hsc70 expression was not altered at any of these ages. Determination of Hsp70 and Hsc70 expression in isolated liver cell types showed that Hsp70 is expressed only in the liver hepatocytes, while Hsc70 is expressed in all liver cell types. It is likely that stressed hepatocytes can release excess Hsp70 into the circulation, thus contributing to increased atherosclerosis as reported in the literature. Hsp70 induction was also associated with increased CpG site methylation at +503 to $+856 \mathrm{bp}$, thus indicating epigenetic change.

Lastly, I showed that prenatal and "whole-life" arsenic exposures at lower exposures (4.9 and $1 \mathrm{ppm}$ arsenic) increased atherosclerotic lesion formation in aortic aches, which was associated with altered plasma triglyceride and cholesterol. However, there was no difference in lesion formation between prenatal and "whole-life" exposures. Both exposure types also increased plasma cytokine/chemokine expression, thus indicating inflammation which is proatherogenic. Thus, infants are at high risk of developing atherosclerosis even at very low exposure levels. 


\section{TABLE OF CONTENTS}

PAGE

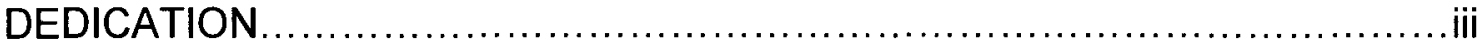

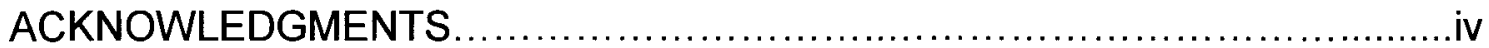

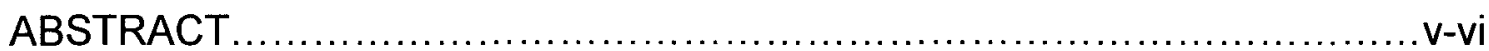

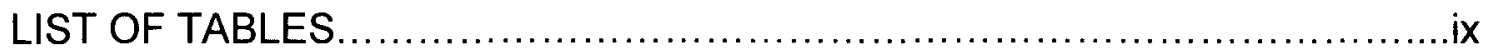

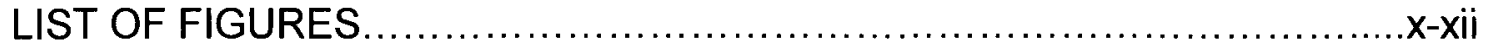

CHAPTER I: General Introduction..........................................

CHAPTER II: Prenatal arsenic exposure induces subtle postnatal hepatic damage and systemic inflammation associated with accelerated atherosclerosis in ApoE knockout mice

Introduction ................................................... 8

Materials and Methods.....................................10-13

Results.........................................................

Discussion......................................................

CHAPTER III: Delayed temporal increase of hepatic Hsp70 expression in ApoE knockout mice after prenatal arsenic exposure

Introduction .................................................. 25-27

Materials and Methods.....................................28-36

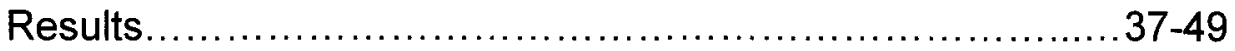

Discussion..................................................... $50-55$

CHAPTER IV: Differential Hsp70, Hsc70, GST-alpha and TNF-alpha expression in hepatocytes, kupffer cells, sinusoidal endothelial cells and stellate cells isolated from ApoE knockout mice exposed to arsenic prenatally

Introduction

Materials and Methods ...................................... $58-63$

Results............................................................ 
Discussion

CHAPTER V: Prenatal arsenic exposure at low exposure levels increases atherosclerotic lesion formation and plasma inflammatory cytokines/chemokines related to cardiovascular disease

Introduction 73-74

Materials and Methods. $75-78$

Results $79-89$

Discussion. $.90-95$

CHAPTER VI: General Conclusions and future studies. 96-101

REFERENCES $102-110$

APPENDIX: List of abbreviations. $111-113$

CURRICULUM VITAE. $114-117$ 


\section{LIST OF TABLES}

TABLES

PAGE

3.1 Oligonucleotides used in amplifying and sequencing $H s p 70$ in bisulfite

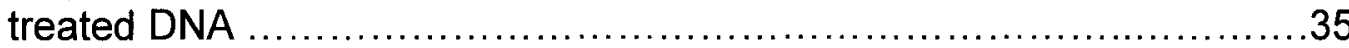

3.2 MiRNAs decreased by prenatal arsenic exposure and predicted to have sites on Hsp70 mRNA as predicted by miRWalk and other programs....49

5.1 Average daily arsenic water consumption .............................. 80

5.2 Effects of arsenic exposure on body weight........................... 81 


\section{LIST OF FIGURES}

FIGURE - PAGE

2.1 Effects of prenatal arsenic exposure and LPS on liver histology ...........15

2.2 Effects of prenatal arsenic exposure and LPS on indices of liver injury...16

2.3 Effects of prenatal arsenic exposure and LPS on inflammatory cytokine

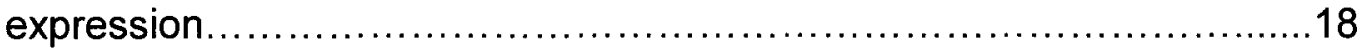

2.4 Effects of prenatal arsenic exposure and LPS on hepatic TNF-alpha

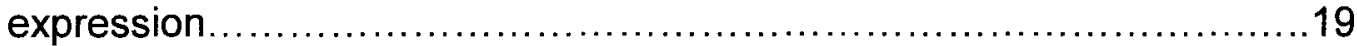

3.1 Schematic representation of $H s p 70$ showing analyzed regions ..........36

3.2 ICP-MS analysis of GD18 fetal and maternal hepatic arsenic content....38

3.3 Western blot analysis of hepatic $\mathrm{Hsp} 70$ and $\mathrm{Hsc70}$ expression during course of prenatal and postnatal development.

3.4 Analysis of global DNA methylation during course of prenatal and postnatal development.

3.5 Analysis of $\mathrm{Hsp} 70$ promoter region and $\mathrm{CpG}$ island methylation

3.6 Western blot analysis of Hsf1 and $\mathrm{Nr} 2$ cytosolic and nuclear protein levels

4.1 Effects of prenatal arsenic exposure on $\mathrm{Hsp} 70$ and Hsc70 expression in isolated liver cell types.

4.2 Effects of prenatal arsenic exposure on GST-alpha expression in isolated liver cell types

4.3 Effects of prenatal arsenic exposure on TNF-alpha expression in isolated liver cell types.

5.1 Effects of low dose prenatal arsenic exposure on atherosclerotic lesion formation

5.2 Effects of "whole-life" arsenic exposure on atherosclerotic lesion formation.

5.3 Effects of arsenic exposure on plasma lipids 86 
5.4 Effects of prenatal arsenic exposure on plasma cytokine/chemokine

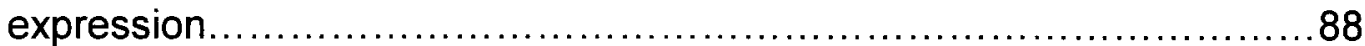

5.5 Effects of "whole-life" arsenic exposure on plasma cytokine/chemokine expression. 


\section{CHAPTER I}

\section{GENERAL INTRODUCTION}

\section{Arsenic in drinking water}

Inorganic arsenic is a naturally occurring element and contaminated drinking water is a major route of exposure. Contamination of drinking water by arsenic is a major worldwide public health problem. Both the world health organization (WHO) and the United States Environmental Protection Agency (USEPA) decreased the maximum contaminant level $(\mathrm{MCL})$ for arsenic in drinking water from $50 \mu \mathrm{g} / \mathrm{L}$ to $10 \mu \mathrm{g} / \mathrm{L}$ to more sufficiently protect public health. However, there are many areas around the world (United States inclusive) with drinking water arsenic levels exceeding $10 \mu \mathrm{g} / \mathrm{L}$, and very high levels (sometimes $>300 \mu \mathrm{g} / \mathrm{L}$ ) occur in Bangladesh, Taiwan, India, Chile and Argentina (Ahmed et al., 2006; Nordstrom, 2002). In this dissertation, drinking water arsenic was used as a route of arsenic exposure.

\section{Arsenic and atherosclerosis}

Chronic ingestion of arsenic contaminated drinking water is associated with a variety of human diseases. Inorganic arsenic is an established human carcinogen causing cancer of the skin, lung and bladder. However, arsenic is also atherogenic, although the atherogenic effect of arsenic is less well 
established. Accumulating evidence from both epidemiological and experimental animal studies show that arsenic exposure causes cardiovascular disease (CVD). Epidemiological studies in the endemic area of Taiwan show a doseresponse effect of arsenic exposure and atherosclerosis (Chen et al., 1996; Tseng, 2008; Wang et al., 2007). Furthermore, epidemiologic studies in populations with high arsenic exposures show increased incidence of CVD which include carotid atherosclerosis (Wang et al., 2002), hypertension (Chen et al., 1995) and ischemic heart disease (Hsueh et al., 1998). Even in areas where arsenic levels are much lower, for example the United States, arsenic exposure is associated with mortality from arterial disease (Engel and Smith, 1994).

Atherosclerosis underlies most CVD which is the leading cause of death in the world. There is a strong correlation between arsenic exposure and atherosclerosis as demonstrated by epidemiological studies in adults (Tseng, 2008; Wang et al., 2007) and experimental animal models (Srivastava et al., 2007; Srivastava et al., 2009). The induction of atherosclerosis by drinking water arsenic is dose-dependent with exposures as low as $1 \mathrm{ppm}$ and $250 \mathrm{ppb}$ arsenic reported to induce the disease in mice (Lemaire et al., 2011; Srivastava et al., 2009). However, the exact mechanism by which arsenic causes atherosclerosis is not clearly understood. In this dissertation, the possible mechanisms of arsenic-induced atherosclerosis were determined.

Accumulating data suggest that early life exposures may play a significant role in the onset of environmental adult diseases (Barker, 2007). A role for prenatal arsenic exposure in the development of arterial disease is suggested by reports 
of myocardial infarction in infants from mothers who consumed water with high levels of arsenic in Chile (Rosenberg, 1974; Rosenberg, 1973). Indeed, prenatal exposure to arsenic accelerated atherosclerosis in $\mathrm{ApoE}^{-/-}$mice, even without high fat diet (Srivastava et al., 2007), which is usually requisite for early atherosclerosis in this strain. Mice exposed to arsenic (49 ppm arsenic) prenatal developed $>2$-fold lesions at 10 and 16 weeks of age, compared to mice exposed to tap water while prenatal. These lesions were located in the aortic roots, as well as the aortic arch. Thus, these results suggest that prenatal arsenic exposure may cause irreversible changes that predispose to development of atherosclerosis in adult life. However, it is not determined if the induction of atherosclerosis by prenatal arsenic exposure is dose-dependent. In this dissertation, the dose-response effects of prenatal arsenic exposure in the induction of atherosclerosis was determined.

\section{Liver disease and atherosclerosis}

Although atherosclerosis is a disease of the vasculature, disease modifying risk may be derived from distal sites such as the liver. Indeed, underlying nonalcoholic fatty liver disease (NAFLD) has been shown to be a risk factor for developing atherosclerosis in humans (Brea et al., 2005; Targher et al., 2004) and is independent of other risks associated with chronic liver disease (e.g. metabolic syndrome) (Targher et al., 2006). Several epidemiology studies show that nonalcoholic fatty liver disease (NAFLD) is associated with increased risk of carotid atherosclerosis (Brea et al., 2005; Targher et al., 2004; Targher et al., 2006). Furthermore, some studies (Bellentani et al., 2008) indicate that elevated 
liver enzymes in the plasma (e.g. ALT, AST) are risk factors for coronary events, including atherosclerosis, and appear independent of traditional risk factors. Although the mechanism by which liver disease modulates atherosclerosis is not fully understood, inflammation (Kugelmas et al., 2003; Schindhelm et al., 2007) and abnormal lipid metabolism (Adiels et al., 2006) that occur in liver disease have been proposed to contribute to atherogenesis.

The liver is a known target organ of arsenic toxicity. In humans, chronic arsenic exposure causes hepatic abnormalities, such as hepatomegaly, non-cirrhotic fibrosis, and portal hypertension (Santra et al., 1999; Mazumder, 2005). Chronic arsenic exposure has also been shown to cause liver diseases in animal models (Santra et al., 2000). Exposure to arsenic was also reported to induce liver cancer and other cancers as well in mice after prenatal exposures (Waalkes et al., 2003;Waalkes et al., 2004; Waalkes et al., 2006). In this dissertation, the hypothesis that prenatal arsenic exposure causes basal- or worsens liver damage was tested. in the $\mathrm{ApoE}^{-/-}$mouse model.

\section{Atherosclerosis and inflammation}

Atherosclerosis is a multifactorial and complex disease. Atherosclerosis results from the process of a combination of hyperlipidemia and inflammation. ApoE ${ }^{-/-}$ mice are constitutively hyperlipidemic, but the source of inflammation is not known. Accumulating evidence from many studies shows that inflammation plays a central role in the formation of atherosclerotic plaque. During atherogenesis, there is sub-endothelial retention of cholesterol-rich lipoproteins which lead to endothelial activation. Lipoprotein in the sub-endothelial space is susceptible to 
various modifications including oxidation, enzymatic cleavage, and aggregation, which render these particles pro-inflammatory. Monocytes are rapidly recruited to regions of lipoprotein retention in the intima and transform into macrophages. The macrophages take up oxidized lipids and transform into foam cells. These cholesterol-rich macrophages secrete pro-inflammatory cytokines and enhance lesion formation and atherogenesis. As the atherosclerotic plaque evolves, macrophages are joined by other inflammatory cells (T cells, dendritic cells, neutrophils, mast cells) and local smooth muscle cells that contribute to the cellular environment of the plaque. Genetic deletion of chemokines and cytokines such as MCP-1 and IL-6 in mice decreases atherosclerotic lesion formation (Gu et al., 1998; Schieffer et al., 2004). Increased expression of cytokines and chemokines is reported to be a pro-atherogenic effect of arsenic exposure in vitro (Lee et al., 2005), in vivo (Srivastava et al., 2009) and in humans (Wu et al., 2003). In this dissertation, the role of cytokine and chemokine expression as a pro-atherogenic effect of prenatal arsenic exposure was determined. In addition to cytokines and chemokines mediating inflammatory response during atherogenesis, heat shock protein $70(\mathrm{Hsp} 70)$ is also implicated in atherogenesis as will be discussed below.

\section{Arsenic and Heat shock protein 70}

Heat shock proteins (HSPs) are stress proteins which function as molecular chaperones under physiological conditions, and prevent protein aggregation under stress conditions (Gething and Sambrook, 1992). Hsc70 and Hsp70 are 
members of the HSPA family of HSPs. Hsp70 is the inducible form of heat shock protein 70 which is expressed at low levels under physiological conditions, but induced when cells are stressed (e.g. heat shock, oxidative stress, toxic metals) in order to provide cell survival. Hsc70 is constitutively expressed and functions as a molecular chaperone assisting in protein folding. Arsenic exposure induces the expression of Hsp70 in vitro and in vivo. In addition to the expression of Hsp70 in cells and tissues during stress, stressed cells can also release Hsp70 into the circulation in membrane-bound subcellular particles called exosomes (Asea, 2007). Exosomal Hsp70 expression can activate immune cells such as macrophages to secrete TNF- $\alpha$ and thus provide an inflammatory stimulus for atherogenesis (Vega et al., 2008). Accumulating evidence implicates the role of Hsp70 in atherosclerosis, with Hsp70 expression increased in atherosclerotic lesion sites (Lu and Kakkar, 2010) and also in plasmas of patients with atherosclerosis (Wright et al., 2000; Zhu et al., 2003). However, it is not clearly understood if circulating Hsp70 has a cytoprotective or cytotoxic role in atherogenesis (Bielecka-Dabrowa et al., 2009). In this dissertation, the effects of arsenic exposure on circulating exosomal Hsp70 expression were determined.

\section{Arsenic and DNA methylation}

It is well established that arsenic has epigenetic potential affecting DNA methylation and histone modifications, thus regulating gene expression. Arsenic can alter genome-wide DNA methylation or gene-specific methylation (Reichard and Puga, 2010). Arsenic-induced global DNA hypomethylation and promoter 
region hypermethylation have been implicated in arsenic carcinogenesis (Reichard and Puga, 2010). In addition to DNA methylation, histone modifications are also epigenetic marks that modulate gene expression. Arsenic has been shown to alter histone methylation and acetylation (Ramirez et al., 2008; Zhou et al., 2008). Thus, in this dissertation, the epigenetic effects leading to altered gene expression by arsenic exposure in the $\mathrm{ApoE}^{-/-}$mouse model was determined. 


\section{CHAPTER II}

\section{PRENATAL ARSENIC EXPOSURE INDUCES SUBTLE POSTNATAL HEPATIC DAMAGE AND SYSTEMIC INFLAMMATION ASSOCIATED WITH ACCELERATED ATHEROSCLEROSIS IN APOE ${ }^{-/}$MICE}

\section{Introduction}

Atherosclerosis is a complex process of a combination of hyperlipidemia and inflammation. ApoE ${ }^{-/-}$mice are constitutively hyperlipidemic, but the source of inflammation in the arsenic-exposed mice is not known. We hypothesize that prenatal arsenic exposure primes the liver to a pro-inflammatory state which worsens liver disease upon stimulation, and provides an inflammatory stimulus for atherosclerosis. Microarray analyses of both mRNA and microRNA of livers of 10 week old mice showed that prenatal arsenic exposure increased the expression of the pro-inflammatory cytokine TNF- $\alpha$ postnatally (States et al., 2009), thus suggesting a state of pro-inflammation.

The risk of developing liver disease from environmental exposure (e.g. arsenic) can be modified by other conditions such as other environmental or genetic factors. An environmental exposure can result in physiological/biochemical changes in the liver that are pathologically inert, but that can sensitize the liver to hepatotoxicity caused by a second agent. An example of this "2-hit" hypothesis 
was shown by enhanced lipolysaccharide (LPS)-induced liver injury in mice chronically exposed to arsenic postnatally However, whether prenatal arsenic exposure modifies the risk of developing liver damage owing to other insults has not been determined.

The purpose of the current study was to test the hypothesis that prenatal arsenic exposure may also sensitize the liver to damage caused by a second hit, and thus provide the stimuli for accelerated atherosclerosis. To test this hypothesis, the LPS challenge assay was used to determine the effect of prenatal arsenic exposure on LPS-induced liver damage. 


\section{Materials and Methods}

\section{Animals and treatment}

ApoE $^{-/-}$C57BL/6J mice (B6.129P2-ApoEtm1Unc/J, Jax Labs, Bar Harbor, ME) were housed in a pathogen-free barrier facility accredited by the Association for Assessment and Accreditation of Laboratory Animal Care, and procedures were approved by the local Institutional Animal Care and Use Committee. Pregnant mice were given tap water (for controls) or water containing $85 \mathrm{mg} / \mathrm{L} \mathrm{NaAsO} \mathrm{N}_{2}(49$ ppm arsenic) on gestation day (GD) 8 - GD18. Their male offspring were kept until 10 and 24 weeks old. In some of the mice, experimental liver damage was induced by challenging them with LPS. LPS is a Gram-negative bacterial wall product that is often elevated in systemic blood during liver disease, ( $\mathrm{Li}$ and Diehl, 2003) and is employed in basic research as a model toxicant to the liver. Mice were given a bolus injection of LPS $(10 \mathrm{mg} / \mathrm{Kg})$ intraperitoneally (IP). This dose of LPS (serotype 055:B5, batch 075K4038; Sigma St. Louis, MO) has been determined to cause moderate liver damage with no signs of toxicity to other target organs (Arteel et al., 2008). Twenty-four hours after LPS injection, mice were anesthetized with pentobarbital $(150 \mathrm{mg} / \mathrm{Kg})$. Blood was withdrawn by cardiac puncture and citrated plasma was stored at $-80^{\circ} \mathrm{C}$ for further analysis. Portions of liver tissue were frozen immediately in liquid nitrogen while others were fixed in $10 \%$ neutral buffered formalin or frozen-fixed. 


\section{Histopathological analysis}

Liver tissues from 10 week old arsenic-exposed and unexposed mice and from mice that were dissected $24 \mathrm{~h}$ after LPS challenge were fixed in $10 \%$ neutral buffered formalin and embedded in paraffin. The paraffin-embedded liver sections were cut at $5 \mu \mathrm{m}$ and mounted on glass slides. Sections were deparaffinized and stained with hematoxylin and eosin (H/E) for histological assessment. Neutrophil accumulation in the livers was assessed by staining tissue sections for chloroacetate esterase (CAE), using a napthol AS-D chloroacetate esterase kit (Sigma, St. Louis MO). Results were analyzed by counting the number of CAE positive-stained cells per 1000 hepatocytes.

\section{Determination of plasma ALT and AST}

Blood obtained from 10 and 24 week old arsenic-exposed and unexposed mice and from mice that were dissected $24 \mathrm{~h}$ after LPS challenge was centrifuged at 4,600 rpm to collect plasma. Plasma levels of alanine aminotransferase (ALT) and aspartate aminotransferase (AST) were determined enzymatically using the commercial kit purchased from Infinity Liquid Reagents (Thermo Electron Corporation, Pittsburg).

\section{Determination of plasma IL-6 and TNF-a}

Blood obtained from cardiac puncture of 10 week old arsenic-exposed and unexposed mice and from mice that were dissected $24 \mathrm{~h}$ after LPS challenge was centrifuged at $4,600 \mathrm{rpm}$ to collect plasma. Plasma expression of the pro- 
inflammatory cytokines TNF- $\alpha$ and IL- 6 was measured by ELISA (R \& D Systems, Minneapolis, MN).

\section{Western blot analysis}

Frozen livers from 10 week old arsenic-exposed and unexposed mice and from mice that were dissected $24 \mathrm{~h}$ after LPS challenge challenge were homogenized in SDS lysis buffer (10 mM Tris-HCL pH 7.4, 1 mM EDTA, $0.1 \%$ SDS, $1 \mathrm{mM}$ PMSF, $1 \mu \mathrm{g} / \mathrm{mL}$ aprotinin, $1 \mu \mathrm{g} / \mathrm{mL}$ leupeptin, and $1 \mu \mathrm{g} / \mathrm{mL}$ pepsatin). Liver homogenates were centrifuged and the supernatant obtained. Protein concentrations were determined by bicinchoninic acid protein assay (Thermo Scientific, Rockford, IL).

Proteins $(20 \mu \mathrm{g})$ were separated by sodium dodecyl sulphate polyacrylamide gel electrophoresis (SDS-PAGE). Proteins were transferred to nitrocellulose membrane and blots were probed with rabbit monoclonal TNF- $\alpha$ antibody (1:1000) overnight at $4{ }^{\circ} \mathrm{C}$ (Cell Signaling Technology Inc., Danvers, MA). Membranes were incubated with corresponding rabbit secondary antibodies bound to horse radish peroxidase (HRP). Bound antibodies were visualized using enhanced chemiluminescence plus substrate (GE Healthcare Bio-Sciences Corp., Piscataway, NJ), and visualized directly on a Storm Phosphoimager in blue flourescence mode (Molecular Dynamics, Sunnyvale, CA). Bands were quantitated using Image Quant software. 


\section{Statistical analysis}

Data are expressed as mean \pm SEM. Comparisons among groups were performed using one-way ANOVA and student's t-test. 


\section{Results}

\section{Effects of arsenic exposure on liver damage}

The effects of arsenic on basal and LPS-induced liver damage was analyzed by histologic assessment for necroinflammation and neutrophil infiltration. H/E staining of livers of 10 week old mice showed that arsenic exposure did not cause major macroscopic changes in liver histology in the absence or presence of LPS (Fig. 2.1 A). LPS injection also did not produce any major macroscopic changes in hepatic histology.

Chloroacetate esterase staining for neutrophil infiltration showed that arsenic alone did not significantly increase hepatic neutrophil infiltration (Fig. 2.1 B and C). LPS alone caused a robust infiltration of neutrophils in the liver. Arsenic preexposure did not enhance LPS-stimulated neutrophil infiltration.

\section{Response of plasma ALT and AST to arsenic and LPS}

The effect of arsenic exposure and LPS on circulating enzyme markers of liver injury was also determined. Prenatal arsenic exposure alone significantly increased plasma ALT and AST by a factor of $\sim 2$ in livers of 10 week old mice

(Fig. 2.2 A), and of $\sim 1.5$ in livers of 24 week old mice (Fig. 2.2 B), thus indicating modest liver damage. As expected, LPS alone caused liver injury, as indicated by a significant increase in plasma ALT and AST by a factor of $\sim 2$ and 3 respectively in livers of both 10 and 24 week old mice. Arsenic alone did not significantly enhance LPS-stimulated liver damage at either age. 

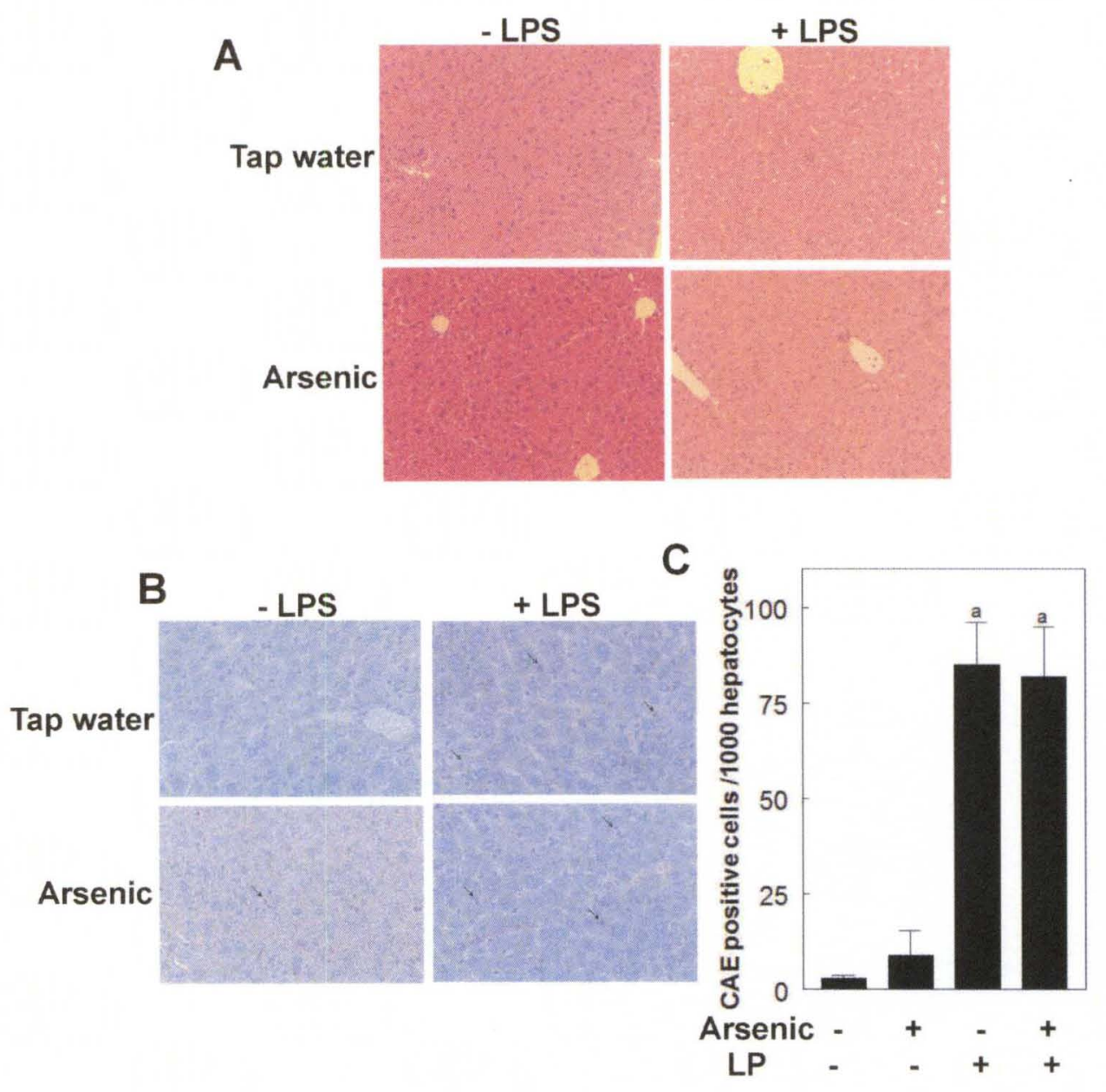

Figure 2.1. Effects of prenatal arsenic exposure and LPS on liver histology of 10 week old mice. Ten week old prenatal arsenic-exposed and unexposed mice were injected with LPS as described in Materials and Methods. Mice were killed $24 \mathrm{~h}$ after LPS injection. Formalin-fixed liver sections were stained with H/E for necroinflammation, and CAE for neutrophil infiltration. Data are mean \pm SEM. $a=p<0.05$ Panel A: Representative photographs of H/E stains; 200x. Panel B: Representative photographs of CAE stains; 200 x. Panel C: Quantitation of CAE positive cells 


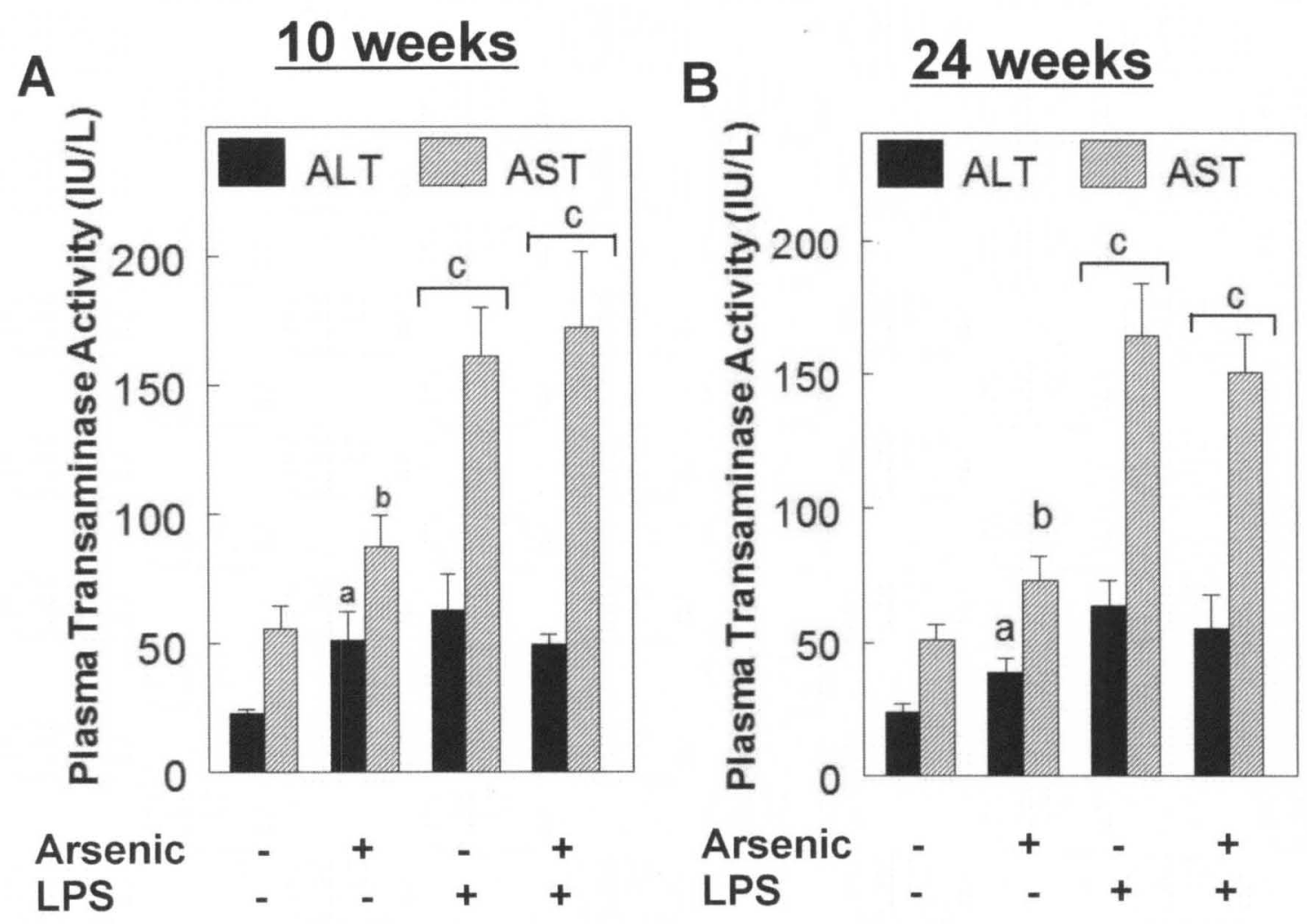

Figure 2.2. Effects of prenatal arsenic exposure and LPS on circulating plasma markers of liver damage in 10 and 24 week old mice. Ten $(A)$ and 24 (B) week old prenatal arsenic-exposed and unexposed mice were injected with LPS as described in Methods. Twenty-four hours after LPS injection, the mice were harvested and the plasma ALT and AST levels were analyzed. $a=p<0.03$ compared to the absence of arsenic. $b=p<0.06$ compared to the absence of arsenic. $c=p<0.05$ compared to the absence of LPS. Data are mean \pm SE. $n=6-8$ 


\section{Response of plasma IL-6 and TNF- $\alpha$ to arsenic and LPS}

Basal levels of plasma IL-6 were higher in mice with prenatal arsenic exposure (Fig. 2.3 A). In contrast, basal level of plasma TNF- $\alpha$ was not changed by arsenic exposure (Fig. 2.3 B). LPS injection produced a robust inflammatory state as indicated by the increased levels of plasma TNF- $\alpha$ and IL-6. Arsenic preexposure appeared to enhance TNF- $\alpha$ and IL-6 expression owing to LPS injection, but data failed to achieve statistical significance. However, arsenic preexposure produced quite robust TNF- $\alpha$ response in 3 out of 6 mice, and IL- 6 response in 2 out of 6 mice, indicating animal to animal variability.

\section{Response of hepatic TNF- $\alpha$ to arsenic and LPS}

Prior work on microarray analysis of mRNA and miRNAs of livers of 10 week old mice showed that prenatal arsenic exposure increased the TNF-a proinflammatory pathway (States et al., 2009a). Thus, I determined the effect of arsenic exposure and LPS challenge on hepatic TNF- $\alpha$ expression by western blot analysis. The data in figure 1.4 show that whereas hepatic TNF- $\alpha$ expression was significantly increased by LPS injection, arsenic exposure did not alter the basal or LPS-stimulated induction of TNF- $\alpha$ expression. 


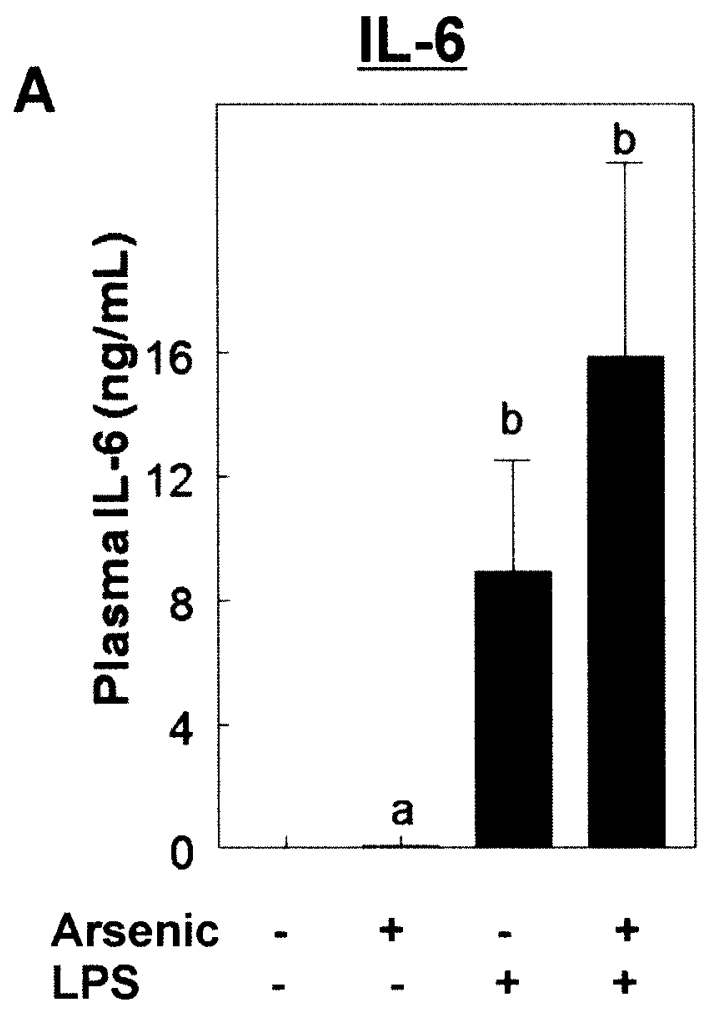

B

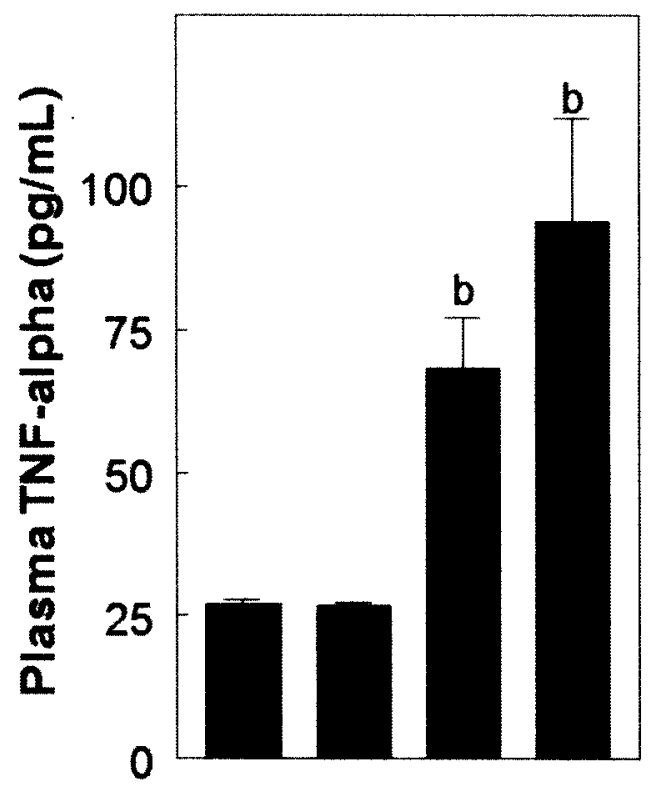

Arsenic - + $\quad$ +

Figure 2.3. Effects of prenatal arsenic exposure and LPS on inflammatory cytokine induction in $\mathbf{1 0}$ week old mice. Ten week old prenatal arsenicexposed and unexposed mice were injected with LPS as described in Methods. Twenty-four hours after LPS injection, the mice were harvested and plasma IL-6 $(A)$ and TNF- $\alpha(B)$ levels were measured by ELISA. $a=p<0.05$ compared to the absence of arsenic. $b=p<0.05$ compared to the absence of LPS. Data are mean \pm SE. $n=6-9$. 
A
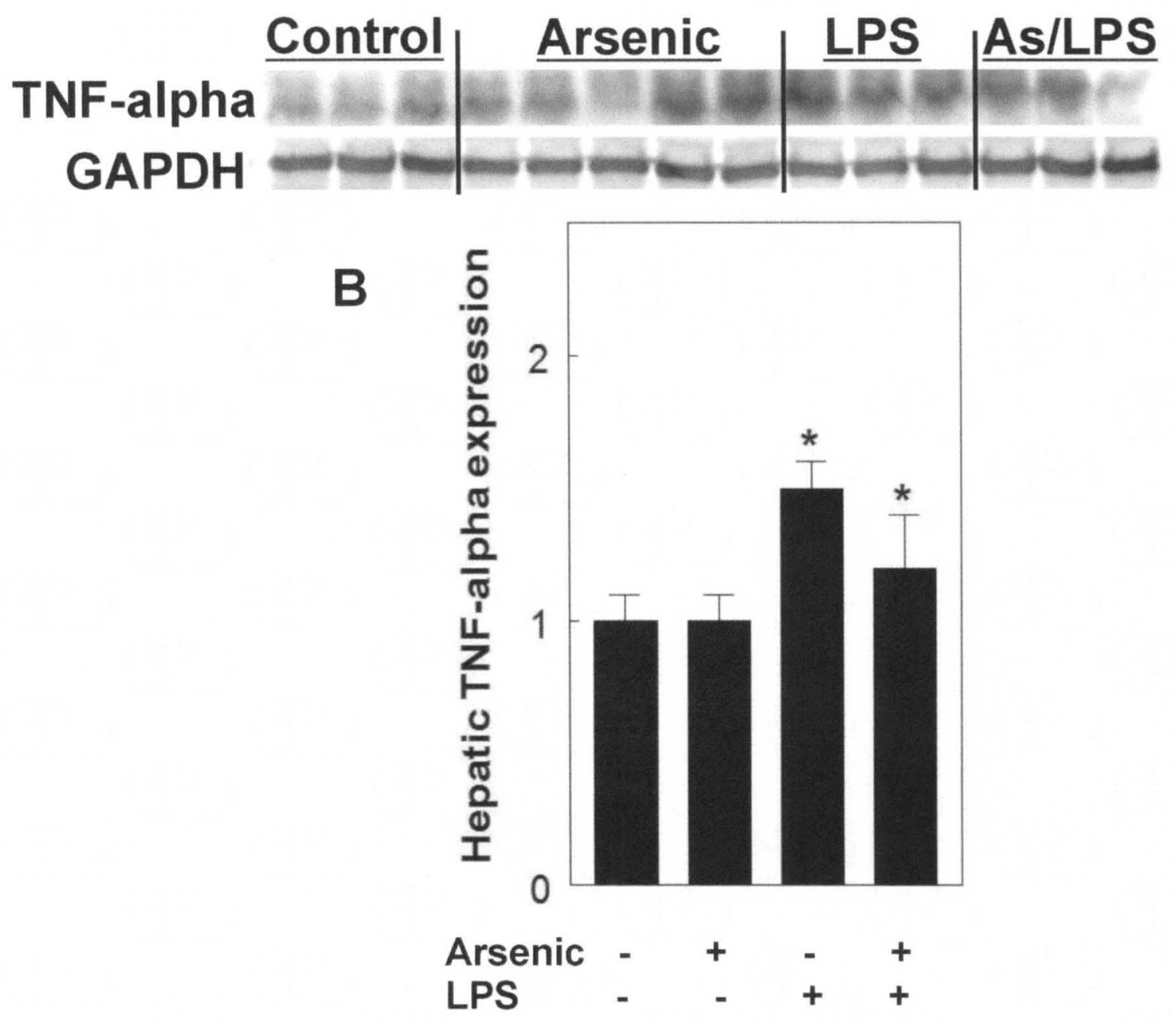

Figure 2.4. Effects of prenatal arsenic exposure and LPS on hepatic TNF- $\alpha$ expression of 10 week old mice. Livers from 10 weeks old arsenic-exposed and unexposed mice dissected $24 \mathrm{~h}$ post LPS challenge were homogenized in SDS lysis buffer for total protein isolation. Western blot analysis was performed to probe for TNF-alpha. Data are mean \pm SEM, $n=6-10 .{ }^{*}=p<0.05$. Panel A: Representative western blot images. Panel B: Densitometric quantitation of TNFalpha. 


\section{Discussion}

In this study, the "2-hit" hypothesis was tested to determine whether prenatal arsenic exposure enhances liver damage owing to a secondary insult. This hypothesis was tested by challenging prenatally arsenic exposed or unexposed mice with a bolus dose of LPS and sacrificing the mice $24 \mathrm{~h}$ later. Liver damage can be assessed histopathologically for necroinflammation and neutrophil infiltration. Several studies show that liver damage caused by arsenic exposure is characterized by abnormal histological changes. Epidemiology studies (Mazumder, 2005) report the manifestation of hepatic histological abnormalities by arsenic exposure. In animal studies, arsenic-induced liver damage ( 3.2 and $200 \mathrm{ppm}$ arsenic) is characterized by abnormal histological changes in the livers of $\mathrm{C} 3 \mathrm{H}$ and Balb/c mice after several months of exposures (Santra et al., 2000; Santra et al., 2000; Wu et al., 2008). In fact, Santra et al. 2000 reported that chronic arsenic exposure for up to 9 months did not cause changes in liver histology, but the appearance of histological changes occurred only after 12 months of exposure. Exposure to $49 \mathrm{ppm}$ arsenic in drinking water for 7 months enhanced LPS-induced hepatic histological changes by increasing necroinflammatory foci (Arteel et al., 2008).

There is also a strong correlation between liver disease and atherosclerosis. Epidemiological studies show that the severity of histological features of NAFLD is strongly correlated with carotid atherosclerosis (Brea et al., 2005;Targher et al., 2006). In the present study, prenatal arsenic exposure alone, or in the presence of LPS did not cause any detectable macroscopic changes in the liver 
as assessed by $\mathrm{H} / \mathrm{E}$ and $\mathrm{CAE}$ staining. These results are different from those reported in the literature probably because the arsenic exposure was very brief (only 10 days prenatal) as compared to the chronic (7 or 12 months) postnatal exposures used in the reported studies. Furthermore, I used $\mathrm{ApoE}^{--}$mouse in C57BL/6 background strain which is genetically different form the C57BL/6 mouse strain used in the Arteel et al. study. In addition, there are differences in atherosclerosis induction between prenatal- and postnatal arsenic exposures, with chronic postnatal exposure inducing more lesion formation (3-5 fold) than prenatal exposures ( 2 fold) (Srivastava et al., 2007; Srivastava et al., 2009).

Circulating concentrations of the liver transaminases, ALT and AST have been used as markers of NAFLD. Several epidemiologic and animal studies show that arsenic-induced liver damage is characterized by elevated plasma liver enzymes. Elevated plasma ALT and AST are seen with liver damage after chronic arsenic exposure in both humans (Mazumder, 2005) and in experimental animals (Santra et al., 2000; Wu et al., 2008). Chronic arsenic exposure for 7 months did not alter plasma liver enzymes, but enhanced elevated plasma liver enzymes induced by LPS (Arteel et al., 2008). There is also a strong correlation between NAFLD and plasma liver enzymes and increased risk of atherosclerosis. Elevated plasma ALT predicts coronary heart disease events in humans, independent of traditional CVD risk factors (Adibi et al., 2007; Schindhelm et al., 2007). Other epidemiological studies (Brea et al., 2005;Targher et al., 2006) show that elevated ALT and AST increase the risk of developing atherosclerosis. Consistent with what is reported in the literature, I have shown that prenatal 
arsenic exposure caused slight but significant elevated plasma ALT and AST postnatally (10 and 24 weeks) thus suggesting liver damage. This is the first animal study to report arsenic-induced plasma ALT and AST in an atherosclerosis animal model. These data indicate a correlation between liver disease (as indicated by elevated plasma liver enzymes) and increased incidence of atherosclerosis, consistent with human epidemiology. Whereas it is not quite clear why the effects of prenatal arsenic exposure on plasma liver enzymes were attenuated by LPS challenge instead of the anticipitated enhancement, there exists a possible explanation. It is possible that the dose of LPS used for the study is high such that it masks the mild effects of prenatal arsenic exposure. This LPS dose was used for the Arteel et al. 2008 study with chronic arsenic exposure.

Liver injury can also be characterized by hepatic and/or systemic inflammation. LPS is known to induce inflammatory cytokine expression. Chronic arsenic exposure is reported to increase hepatic TNF-alpha and IL-6 expression associated with liver damage (Das et al., 2005; Wu et al., 2008). In addition, epidemiological studies show that cord blood TNF- $\alpha$ is associated with arsenic exposure (Ahmed et al., 2011). In the present study, I determined the effect of prenatal arsenic exposure on the basal and LPS-stimulated expression of proinflammatory cytokine IL- 6 and TNF- $\alpha$. The data show that whereas LPS injection increased systemic TNF- $\alpha$ and IL- 6 expression, prenatal arsenic exposure alone increased systemic IL- 6 but not TNF- $\alpha$ expression. Arsenic exposure did not significantly enhance LPS-induced expression of these cytokines. However, 
there appeared to be an interaction effect between arsenic exposure and LPS, as indicated by the apparent increase in cytokine expression in the arsenic/LPS group when compared to LPS alone. Although arsenic did not significantly increase the LPS-stimulated levels of, IL-6 and TNF- $\alpha$, there was animal variability in response, with about half of the mice showing very elevated response. Prior work showed that prenatal arsenic exposure increased the TNFa pro-inflammatory pathway as analyzed by microarray analysis of mRNA and miRNA of livers of 10 week old mice (States et al., 2009). However, western blot analysis showed that prenatal arsenic exposure did not increase hepatic TNF- $\alpha$ expression. These data are inconsistent with previous reports probably due to the short-term exposure I did, compared to chronic exposure. The absence of a significant arsenic effect upon LPS injection might be because the cytokines have passed their peak levels in the plasma at the $24 \mathrm{~h}$ time point.

In summary, this study demonstrates that exposure to arsenic prenatally causes subtle but significant liver damage observed postnatally at 10 weeks that continues at least until 24 weeks. This liver damage is characterized by increased plasma ALT and AST levels, with no macroscopic histologic changes. Arsenic exposure increased systemic- but not hepatic inflammation. We don't yet know if the damage is permanent or temporal. Thus, further studies are required for later time points.

In conclusion, these results suggest that prenatal arsenic exposure induces subtle but significant liver damage, characterized by only elevated plasma liver 
enzymes and systemic inflammation. The observed liver damage is associated with increased atherosclerosis observed in the $\mathrm{ApoE}^{-1-}$ mouse model. 


\section{CHAPTER III}

\section{DELAYED TEMPORAL INCREASE OF HEPATIC HSP70 IN APOE KNOCKOUT MICE AFTER PRENATAL ARSENIC EXPOSURE}

\section{Introduction}

Epidemiological studies indicate chronic arsenic exposure is associated with high risk of CVD (States et al., 2009). Atherosclerosis underlies most CVD, which is the leading cause of mortality worldwide. Arsenic exposure in drinking water accelerates atherogenesis in experimental animal models, (Simeonova et al., 2003) and the induction is dose-dependent (Srivastava et al., 2009). However, the mechanism of arsenic-induced atherogenesis is unknown.

Gestation is a critical period of development. Arsenic readily crosses the placenta in humans and rodents (Concha et al., 1998; Lindgren et al., 1984). Thus, developmental arsenic exposures can predispose to adult diseases as indicated by induction of liver cancers in adult male mice (Waalkes et al., 2003). Reports of myocardial infarction in infants whose mothers consumed water with high levels of arsenic in Chile (Rosenberg, 1973; Rosenberg, 1974) suggest a role for prenatal arsenic exposure in the development of CVD. Indeed, prenatal arsenic exposure accelerated atherosclerosis in $\mathrm{ApoE}^{-/-}$mice without high fat 
diet, which is usually requisite for early atherosclerosis in this strain (Srivastava et al., 2007).

Although atherosclerosis is a vascular disease, the atherogenic stimulus can come from distant sites, including the liver. Epidemiology studies show that liver disease is an independent risk factor for carotid atherosclerosis (Brea et al., 2005; Targher et al., 2006), and that elevated liver enzymes in the plasma (e.g. ALT, AST) are risk factors for coronary events (Bellentani et al., 2008). Arsenic is toxic to the liver, causing liver diseases in humans and animal models (Guha Mazumder, 2001; Santra et al., 2000). It is likely that prenatal arsenic exposure affects liver development predisposing to adult chronic disease. The hypothesis that prenatal arsenic exposure altered developmental programming of the liver of $\mathrm{ApoE}^{-/}$mice with accelerated atherosclerosis was tested by microarray analyses of both mRNA and microRNA in newborn and 10 week old mice (States et al., 2009). The data showed several differentially expressed genes including constitutive (Hsc70) and inducible (Hsp70) heat shock protein 70; age being the major influence on gene expression thus reflecting developmental changes (States et al., 2009).

HSPs are stress proteins which are constitutively expressed at low levels, but upregulated under stress conditions (e.g. heat shock, toxic metals, oxidative stress) in order to confer protection against such stressors. HSPs function as molecular chaperones under physiological conditions, and prevent protein aggregation under stressed conditions (Gething and Sambrook, 1992). Hsc70 and Hsp70 are members of the HSPA family of HSPs. In spite of numerous in vitro data showing 
Hsp70 induction by arsenic, there are very few in vivo data. Therefore, it is still unclear how Hsp70 expression is regulated postnatally after prenatal arsenic exposure.

One of the mechanisms by which the expression of a gene can be altered is by epigenetic regulation, particularly DNA methylation. Arsenic interferes with genome-wide and site-specific DNA methylation (Reichard and Puga, 2010). Thus, exposure to arsenic prenatal is likely to cause epigenetic alterations, particularly DNA methylation which can lead to altered gene expression.

In this study, the hepatic expression of $\mathrm{Hsp} 70$ and $\mathrm{Hsc70}$ during prenatal and postnatal development was determined in mice prenatally exposed to arsenic. In addition, the epigenetic effects of arsenic were determined. This is the first study to determine how the expression of $\mathrm{Hsp} 70$ changes during early postnatal development following prenatal arsenic exposure. 


\section{Material and Methods}

\section{Chemicals}

Sodium arsenite $\left(\mathrm{NaAsO}_{2}\right)$ was obtained from Sigma Chemical Co. (St. Louis, MO). Adenosyl-L-methionine, S-[methyl- $\left.{ }^{3} \mathrm{H}\right]$; $\left(\mathrm{SAM}\left[{ }^{3} \mathrm{H}\right]\right)$, (specific activity 81.9 $\mathrm{Ci} / \mathrm{mmol}$ ) was purchased from Perkin-Elmer, Inc. (Boston, MA). Protease inhibitors were purchased from Sigma Chemical Co. (St. Louis, MO) and Fisher Scientific (Rockford, IL).

\section{Animal treatment and sample collection}

$\mathrm{ApoE}^{-/-}$mice were housed and bred under pathogen-free conditions in controlled temperature and $12 \mathrm{~h}$ light $/ 12 \mathrm{~h}$ dark cycle. Animal care was provided following the guidelines of the Association for the Accreditation of Laboratory Animal Care. Prior to treatment, all mice were maintained on standard chow diet and tap water as previously described (Srivastava et al., 2007). Briefly, mice were bred by housing 2-4 females with each male. Females were checked daily for the presence of a vaginal plug. The presence of a plug was designated gestational day 0 (GDO), and the female was assumed pregnant. Pregnant mice were housed separately, and were given drinking water containing $85 \mathrm{mg} / \mathrm{L} \mathrm{NaAsO} \mathrm{N}_{2}$ (49 ppm arsenic) or tap water (for controls) ad libitum from GD 8 through GD18. During prenatal arsenic exposures, arsenic containing water was changed twice weekly. Dams were allowed to give birth (GD18-GD21) and male offspring were maintained on tap water and normal chow ad libitum until sacrificed at 3, 10 and 
24 weeks of age. Liver samples were frozen at $-80^{\circ} \mathrm{C}$ until analysis. GD18 dams were also sacrificed and maternal and fetal livers were obtained and stored frozen at $-80^{\circ} \mathrm{C}$. All mice were anesthetized with pentobarbital $(150 \mathrm{mg} / \mathrm{Kg})$ before sacrifice. Studies were performed under protocols approved by the University of Louisville Institutional Animal Care and Use Committee.

\section{Measurement of hepatic arsenic levels by inductively coupled plasma- mass spectrometry (ICP-MS)}

Total arsenic which would include inorganic and organic forms was determined by ICP-MS. Access to the ICP-MS instrument is available through the Center for Regulatory, Environmental and Analytical Metabolomics at University of Louisville on a fee per service basis. We have used this instrument to measure arsenic in cell cultures (McNeely et al., 2008). A portion of the frozen maternal and GD18 fetal liver $(300-600 \mathrm{mg})$ was transferred to $2 \mathrm{~mL}$ acid washed $(0.1 \mathrm{M}$ $\mathrm{HNO}_{3}$ acid) centrifuge tubes and digested in $350 \mu \mathrm{L}$ concentrated nitric acid overnight. One hundred $\mu \mathrm{L}$ of digested sample was transferred to $10 \mathrm{~mL}$ acid washed microwavable digestion tubes in triplicates, and every $3^{\text {rd }}$ sample from each group was spiked with $5 \mathrm{ng}$ arsenic standards (SPEX CertiPrep, Metuchen, $\mathrm{NJ})$. The samples were microwave digested at $150^{\circ} \mathrm{C}$ for $10 \mathrm{~min}$ using Automated Microwave Synthesis Workstation. Residues were removed by centrifugation, and $1.9 \mathrm{~mL}$ of $18 \mathrm{Mohm}$ water containing $10 \mathrm{ppb}$ internal standard solution was added in to every sample to give $5 \% \mathrm{HNO}_{3}$ acid. Each sample (1.5 $\mathrm{mL}$ ) was transferred to acid washed polypropylene deep-well 96 well plates for 
ICP-MS analysis using Thermo Electron ICP-MS, X-Series. Blank was concentrated nitric acid. Results are expressed in ng arsenic/g wet weight.

\section{Isolation of proteins from total liver homogenates}

Frozen livers from GD18 fetuses, and 3, 10 and 24 week old mice were homogenized in ice-cold radioimmunoprecipitation assay (RIPA) buffer ( $50 \mathrm{mM}$ Tris-HCL pH7.4, 1\% NP-40, 0.25\% Na-deoxycholate, $150 \mathrm{mM} \mathrm{NaCl}, 1 \mathrm{~m} \mathrm{M}$ EDTA, $1 \mathrm{mM}$ phenylmethylsulphonyl fluoride (PMSF), $1 \mu \mathrm{g} / \mathrm{mL}$ aprotinin, $1 \mu \mathrm{g} / \mathrm{mL}$ leupeptin, $1 \mu \mathrm{g} / \mathrm{mL}$ pepsatin, $1 \mathrm{mM} \mathrm{Na} \mathrm{VO}_{4}$ and $1 \mathrm{mM} \mathrm{NaF}$ ) or SDS lysis buffer (10 mM Tris-HCL pH7.4, 1 mM EDTA, 0.1\% SDS, $1 \mathrm{mM} \mathrm{PMSF,} 1$ g $/ \mathrm{mL}$ aprotinin, $1 \mu \mathrm{g} / \mathrm{mL}$ leupeptin, and $1 \mu \mathrm{g} / \mathrm{mL}$ pepsatin). Liver homogenates were centrifuged and the supernatants obtained as protein extracts. Protein concentrations were determined by bicinchoninic acid protein assay (Thermo Scientific, Rockford, IL).

\section{Extraction of cytosolic and nuclear fractions}

Livers of 3 and 10 week old arsenic-exposed and unexposed mice were subjected to cytosolic and nuclear extractions. Frozen livers $(0.1 \mathrm{~g})$ were ground in liquid nitrogen and transferred to a dounce homogenizer. Using pestle B, tissues were homogenized in $700 \mu \mathrm{L}$ of ice-cold Polyamine A buffer $(0.34 \mathrm{M}$ sucrose, $13.3 \mathrm{mM}$ Tris- $\mathrm{HCl} \mathrm{pH} 7.5,13.3 \mathrm{mM} \mathrm{NaCl}, 0.1 \%$-mercaptoethanol, 53 mM KCl, 2 mM EDTA, 0.5 mM EGTA, 0.5 mM Spermidine, 0.5 mM Spermine, 1 $\mathrm{mM}$ PMSF, $1 \mu \mathrm{g} / \mathrm{mL}$ aprotinin, $1 \mu \mathrm{g} / \mathrm{mL}$ leupeptin, $1 \mu \mathrm{g} / \mathrm{mL}$ pepsatin, and 
phosphatase inhibitor) about 15 strokes. Dounce homogenizer was rinsed with $300 \mu \mathrm{L}$ of polyamine A buffer. The suspension was transferred to $1.5 \mathrm{~mL}$ centrifuge tubes and centrifuged at $4500 \mathrm{~g}$ for $15 \mathrm{~min}$, at $4^{\circ} \mathrm{C}$. The supernatant, which is the cytosolic fraction, was removed and transferred to a new tube and stored at $-80^{\circ} \mathrm{C}$

The nuclear pellet was resuspended in $300 \mu \mathrm{L}$ of Polyamine A buffer $+2.1 \mathrm{M}$ sucrose solution (mixed in equal ratios), and the suspension was layered on top of $200 \mu \mathrm{L}$ of Polyamine A buffer $+2.1 \mathrm{M}$ sucrose solution (mixed in equal ratios) in centrifuge tubes. Tubes were centrifuged in a Beckman TLA 120.2 rotor at $95,000 \times \mathrm{g}$, for $1 \mathrm{~h}$, at $4{ }^{\circ} \mathrm{C}$. The supernatant was removed and nuclear pellet was lysed in $200 \mu \mathrm{L}$ of Buffer $\mathrm{B}(20 \mathrm{mM}$ Hepes, $1 \mathrm{M} \mathrm{NaCl}, 5 \mathrm{mM} \mathrm{MgCl}, 12 \%$ glycerol, $5 \mathrm{mM}$ DTT, $2 \mathrm{M}$ Urea, $1 \mathrm{mM}$ PMSF, $1 \mu \mathrm{g} / \mathrm{mL}$ aprotinin, $1 \mu \mathrm{g} / \mathrm{mL}$ leupeptin, $1 \mu \mathrm{g} / \mathrm{mL}$ pepsatin, and phosphatase inhibitor) and incubated shaking for $30 \mathrm{~min}$ at $4{ }^{\circ} \mathrm{C}$. Nuclear lysate was centrifuged at $14,000 \times \mathrm{g}$, for $15 \mathrm{~min}$ at $4^{\circ} \mathrm{C}$ and supernatant was collected and stored at $-80^{\circ} \mathrm{C}$ as nuclear extract.

Protein concentrations in cytoplasmic and nuclear extracts were measured using Bio-Rad protein assay.

\section{Western blot analysis}

Proteins $(20-25 \mu \mathrm{g})$ were separated by sodium dodecyl sulphate polyacrylamide gel electrophoresis (SDS-PAGE) and transferred unto nitrocellulose membranes. Membranes were incubated with primary antibodies including mouse monoclonal, and rabbit monoclonal Hsp70 antibodies (1:1000, 
overnight at $4{ }^{\circ} \mathrm{C}$; Enzo Life Sciences International, Inc., Plymouth Meeting, PA, and Epitomics Inc., Burlingame, CA); rat monoclonal Hsc70 antibody (1:1000, $1 \mathrm{~h}$ at $4{ }^{\circ} \mathrm{C}$; Enzo Life Sciences International, Inc., Plymouth Meeting, PA); rabbit polyclonal Hsf1 antibody (1:500, $24 \mathrm{~h}$ at $4{ }^{\circ} \mathrm{C}$; Cell Signaling Technology Inc., Danvers, MA); and rabbit ployclonal Nrf2 antibody $\left(1: 1000\right.$ overnight at $4{ }^{\circ} \mathrm{C}$; Cell Signaling Technology Inc., Danvers, MA). Membranes were incubated with corresponding mouse, rabbit, and rat secondary antibodies bound to HRP. The membranes were incubated with ECL or ECL plus substrate (GE Healthcare BioSciences Corp., Piscataway, NJ). ECL membranes were exposed to Kodak XAR x-ray film. Signals on ECL plus membranes were visualized directly on a Storm Phosphoimager in blue flourescence mode (Molecular Dynamics, Sunnyvale, CA). Bands were quantitated using Image Quant software.

\section{Global DNA methylation assay}

Genomic DNA was isolated from frozen liver tissues of GD18 fetuses and 3, 10 and 24 week old mice by the salting out method. Global DNA methylation was determined by the methyl acceptance assay as described (Xie et al., 2007) with some modifications. Briefly, $2 \mu \mathrm{g}$ DNA was incubated for $2 \mathrm{~h}$ at $37^{\circ} \mathrm{C}$ in a $30 \mu \mathrm{L}$ reaction mixture containing $1.25 \mu \mathrm{M}(3 \mu \mathrm{Ci})\left[{ }^{3} \mathrm{H}\right]-\mathrm{SAM}, 4$ units of $\mathrm{CpG}$ Methylase (M. ss I) (New England Biolabs, Inc., Beverly, MA), 10 mM DTT, Tris-EDTA buffer (100 mM Tris, $10 \mathrm{mM}$ EDTA, $\mathrm{pH} 8.0)$ and $100 \mathrm{mM} \mathrm{NaCl}$. The reaction was stopped on ice and split in two aliquots of $15 \mu \mathrm{L}$. Each aliquot was transferred onto a Whatman DE81 filter to bind DNA. Bound DNA was washed on a filtration 
funnel connected to a vacuum source three times with $5 \mathrm{~mL}$ of $0.5 \mathrm{M}$ phosphate buffer ( $\mathrm{pH} 7.0$ ), once with $5 \mathrm{~mL}$ of $70 \%$ ethanol and twice with $5 \mathrm{ml}$ of absolute ethanol. The filter was dried and $5 \mathrm{~mL}$ of liquid scintillation cocktail (Beckman Coulter, Fullerton, CA) was added. Bound radioactivity was measured by scintillation counting on a Tri-Carb 2910TR liquid scintillation analyzer (Pelkin Elmer, Boston, MA)

\section{Promoter region and $\mathrm{CpG}$ island methylation of Hsp70}

Genomic DNA was isolated from livers of 10 week old arsenic-exposed and unexposed mice and $400 \mathrm{ng}$ DNA was subjected to bisulfite treatment using EZ DNA Methylation Direct Kit (Zymo Research Corp., Irvive CA) according to manufacturer's protocol. PCR primers were designed using the MethPrimer software (http://www.urogene.org/methprimer/index1.html) which designs oligonucleotide primers for methylation PCR. Primers were designed to amplify 5 regions of $H s p 70 \mathrm{CpG}$ island, which spans the promoter region and $66 \%$ of the body of the gene. Primers were also designed to amplify untreated (original) DNA. Bisulfite-treated DNA (50 ng) and untreated DNA (100 ng) was amplified by PCR using High Fidelity Platinum Taq DNA Polymerase (Invitrogen Corp., Carlsbad, CA) according to manufacturer's protocol (see Table 2.1 for PCR primer sequences). PCR products were visualized on a 1.5 - $2 \%$ agarose gel (based on PCR product size) and single distinct bands were observed. PCR products were purified using Multiwell PCR Purification Kit (Qiagen Inc., Valencia, CA) and sequenced using nested oligonucleotides. In this method, 
sodium bisulfite converts all unmethylated cytosines to uracil residues, while 5methyl cytosine is resistant to conversion. PCR amplification then converts the uracils to thymidines. After sequencing, unmethylated cytosines are detected as thymidines, thus making it possible for determination of site-specific methylation.

\section{Statistical analysis}

Data are expressed as mean \pm SEM. Comparisons among groups were performed using one way ANOVA and student's t-test. 
Table 2.1. Oligonucleotides used in amplifying and sequencing $H s p 70$ in bisulfite treated DNA.

\begin{tabular}{|c|c|c|}
\hline Region & Oliqonucleotide Type & Oligonucleotide Sequence \\
\hline \multirow{5}{*}{1} & \multirow{2}{*}{$\begin{array}{c}\text { PCR } \\
\left(\mathrm{Tm}=50^{\circ} \mathrm{C}\right)\end{array}$} & Fw: 5'-TAGTATTTTTAGGAGTTGATTTTTAATAGT-3' \\
\hline & & Rv: 5'-TTATCTCTAAATAAAACCAAATTTAATTCT-3' \\
\hline & \multirow{3}{*}{ Sequencing } & Fw: 5'-TTAGGAGTTGATTTTTAATAGT-3' \\
\hline & & Fw: 5'-TTTGGAGAGTTTTGGATAAG-3' \\
\hline & & Rv: 5'-CCAAATTTAATTCTAAATAACTATC-3' \\
\hline \multirow{6}{*}{2} & \multirow{2}{*}{$\begin{array}{c}\text { PCR } \\
\left(\mathrm{Tm}=58^{\circ} \mathrm{C}\right)\end{array}$} & Fw: 5'-ATTTAGAATTAAATTTGGTTTTATTTAGAG-3' \\
\hline & & Rv: 5'-TATAATTCACCTACACCTTAAACTTATC-3' \\
\hline & \multirow{4}{*}{ Sequencing } & Fw: 5'-TTAAATTTGGTTTTATTTAGAG-3' \\
\hline & & Fw: 5'-GTAATTTTTTTAGGAGTATTTTTG-3' \\
\hline & & FW: 5'-GATTTGGGTATTATTTATT-3' \\
\hline & & Rv: 5'-CACCACCTAAAAAAACCAATAC-3' \\
\hline \multirow{6}{*}{3} & \multirow{2}{*}{$\begin{array}{c}\text { PCR } \\
\left(\mathrm{Tm}=58^{\circ} \mathrm{C}\right)\end{array}$} & Fw: 5'-ATGAAGTATTGGTTTTTTTAGGTGGT-3' \\
\hline & & Rv: 5'-ATCCTTCTTATACTTCCTCTTAAACTCCT-3' \\
\hline & \multirow{4}{*}{ Sequencing } & Fw: 5'-TATTGGTTTTTTTAGGTGGT-3' \\
\hline & & Fw: 5'-GAAGATGAAGGAGAT-3' \\
\hline & & Fw: 5'-GGTAGGTTATTAAGGA-3' \\
\hline & & Rv: 5'-CTTATACTTCCTCTTAAACTC-3' \\
\hline \multirow{5}{*}{4} & \multirow{2}{*}{$\begin{array}{c}\text { PCR } \\
\left(\mathrm{Tm}=55^{\circ} \mathrm{C}\right)\end{array}$} & Fw: 5'-GAAGTATAAGAAGGATATTAGTTAGAATAA-3' \\
\hline & & Rv: 5'-AAAAAAATCCTACAACAACTTCTACAC-3' \\
\hline & \multirow{3}{*}{ Sequencing } & Fw: 5'-AGAAGGATATTAGTTAGAATAA-3' \\
\hline & & Fw: 5'-TAGTATTTAGGTTAGTTTGGAG-3' \\
\hline & & Rv: 5'-TCCTACAACAACTTCTACAC-3' \\
\hline \multirow{8}{*}{5} & \multirow{2}{*}{$\begin{array}{c}\text { PCR } \\
\left(\mathrm{Tm}=60^{\circ} \mathrm{C}\right)\end{array}$} & Fw: 5'-TGTAGAAGTTGTTGTAGGATTTTTTTAA-3' \\
\hline & & Rv: 5'-AATAACCTCCTAACACTTATCCAACAC-3' \\
\hline & \multirow{6}{*}{ Sequencing } & Fw: 5'-AAGTTGTTGTAGGATTTTTTT-3' \\
\hline & & Fw: 5'-GGTTATTTTGATGGGGGATAA-3' \\
\hline & & Fw: 5'-GTAATTTTATTATTTTTATTAAGTAG-3' \\
\hline & & Fw: 5'-GATAATAATTTGTTGGGG-3' \\
\hline & & FW: 5'-GGTAAGGTTAATAAGATTATTAT-3' \\
\hline & & Rv: 5'-CCTCCTAACACTTATCCAAC-3' \\
\hline
\end{tabular}




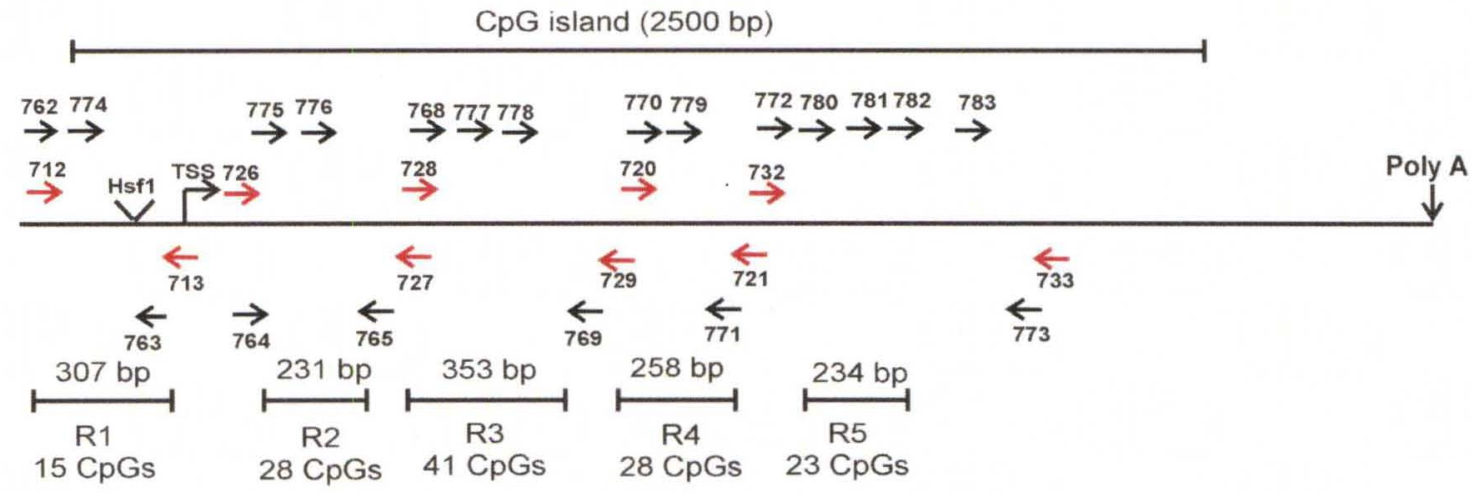

Figure 3.1. Schematic representation of Hsp70 showing regions analyzed for methylation studies. Red arrows indicate PCR primers. Black arrows indicate position of nested sequencing oligonucleotides. 


\section{Results}

\section{GD18 fetal and maternal hepatic arsenic content}

To determine whether maternal arsenic exposure actually reaches the fetus, I measured the maternal and GD18 fetal total arsenic content by ICP-MS. Very little arsenic was detected in unexposed maternal and fetal livers (Fig. 3.2), the source of arsenic being the mouse diet. In contrast, inorganic arsenic exposure increased liver arsenic levels $\sim 55$ fold $(1165 \pm 179 \mathrm{ng} / \mathrm{g}$ wet weight $)$ and $\sim 26$-fold in feta livers ( $350 \pm 20 \mathrm{ng} / \mathrm{g}$ wet weight). The concentration of arsenic detected in the maternal livers was similar to the $\sim 1.5 \mathrm{mg} / \mathrm{kg}$ reported in liver biopsies of humans with chronic arsenic exposure in West Bengal (Mazumder et al., 1998). Thus, my animal exposure model anchors the results to this human population with relatively high arsenic exposure ( $\geq 100 \mathrm{ppm}$ arsenic). These data indicate that maternal arsenic exposure crossed the placental barrier and reached the fetal liver as reported by others (Jin et al., 2006; Lindgren et al., 1984).

\section{Hepatic Hsp70 and Hsc70 expression during course of postnatal development}

Hsp70 is a stress response protein whose expression is induced during stress (e.g. heat shock or toxic metals). Thus, I determined by western blot the effect of prenatal arsenic exposure on Hsp70 expression at different stages of development, in GD18 fetuses (Day 0), and 3 (Day 21), 10 (Day 70), and 24 week old mice (Day 168). The results show that Hsp70 expression was not 


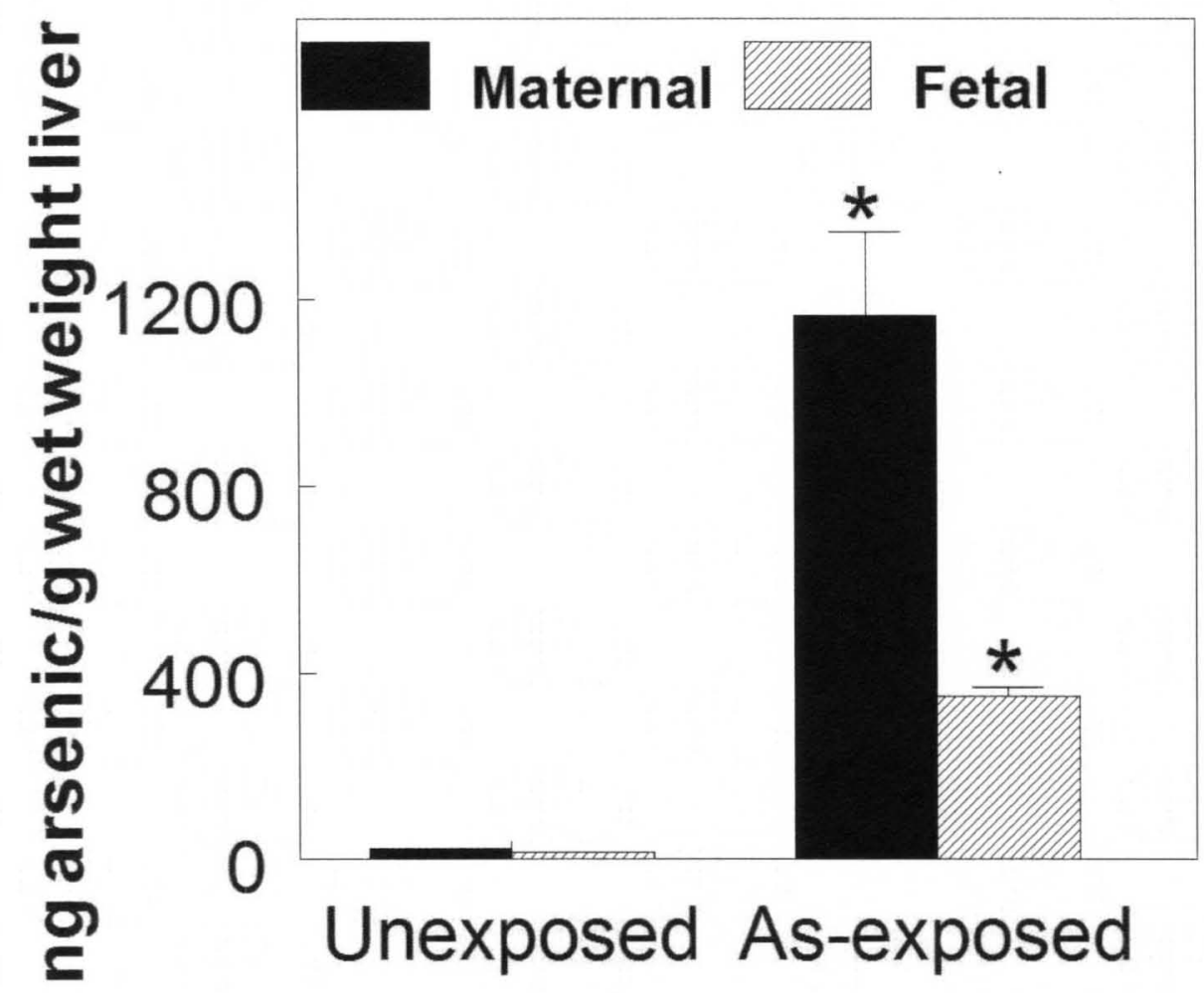

Figure 3.2. ICP-MS analysis of GD18 fetal and maternal hepatic arsenic content. A portion (300-600 mg) of the frozen maternal and GD18 fetal livers was digested in nitric acid. Total arsenic which would include inorganic and organic forms was determined by time of flight-inductively coupled plasma-mass spectrometry (ICP-MS) as described in Materials and Methods. Data are expressed as Mean \pm SEM, $n=3 .{ }^{*}=p<0.02 . \#=p<.003$ 
altered at GD18 at the end of the arsenic exposure (Fig. 3.3 A). However, 21 days later, Hsp70 expression was increased by a factor of $\sim 2$ in arsenic-exposed livers. The increased expression of Hsp70 remained constant at Day 70, but returned to unexposed levels by Day 168 . These data indicate that prenatal arsenic exposure caused a delayed temporal induction of inducible Hsp70, thus suggesting a temporal state of stress in the livers of exposed mice.

In contrast to increased expression observed with inducible Hsp70, the expression of constitutive $\mathrm{Hsc70}$ was not altered during any stage of development (Fig. $33 \mathrm{C}$ ). These data are consistent with constitutive nature of $\mathrm{Hsc70.}$

\section{Global DNA methylation analysis}

The effect of prenatal arsenic exposure on global DNA methylation at different stages of development (GD18 fetuses, and 3, 10 and 24 weeks) was determined by methyl acceptance assay. This assay uses a bacterial DNA methyltransferase that methylates all unmethylated cytosines in DNA. In this assay, SAM labeled with $\left[{ }^{3} \mathrm{H}\right]$ at the donated methyl group is the methyl donor. Thus, lower methyl incorporation corresponds to higher degree of DNA methylation (i.e. hypermethylation). In the DNA of both arsenic-exposed and unexposed mice, incorporation of methyl groups into DNA decreased with increasing age (Fig.

3.4). Thus, liver DNA becomes hypermethylated globally as mice age. However, prenatal arsenic exposure did not alter the global DNA methylation status at any age. 


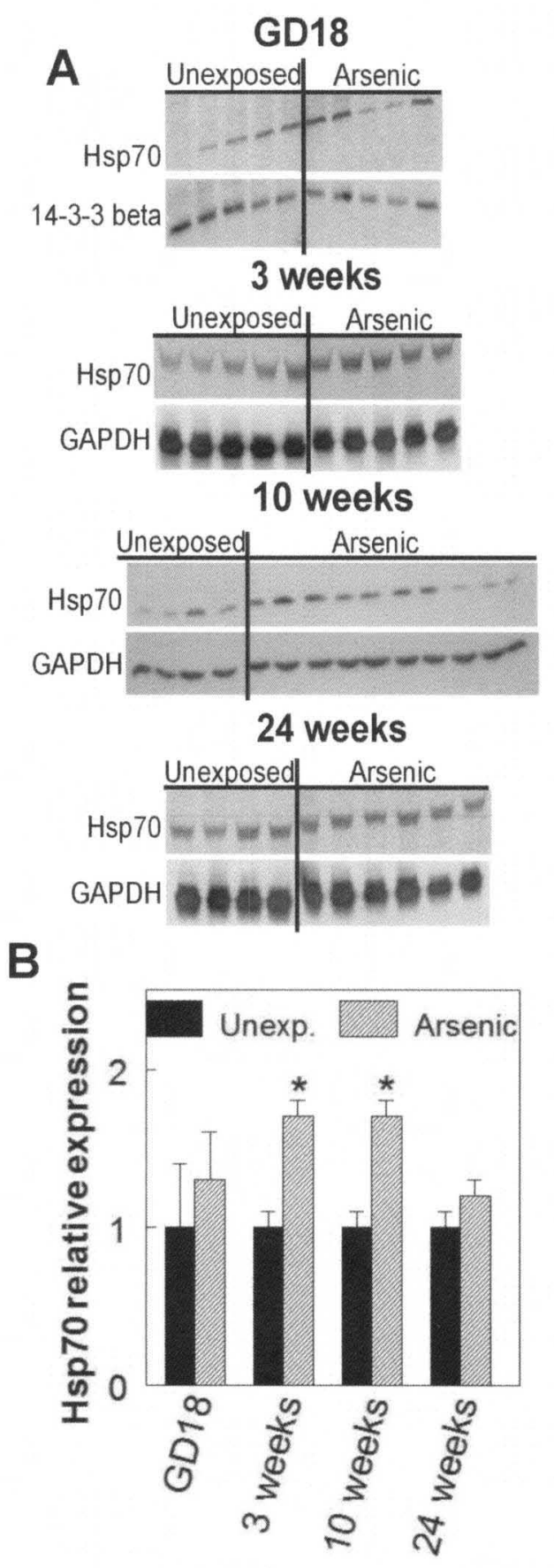

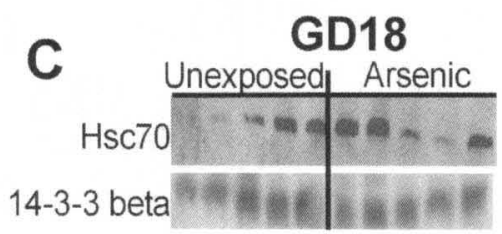
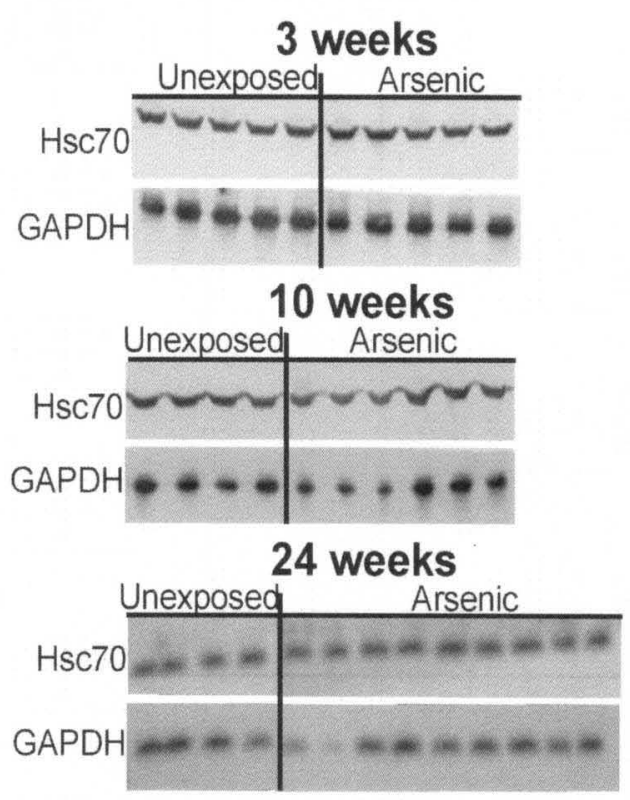

D

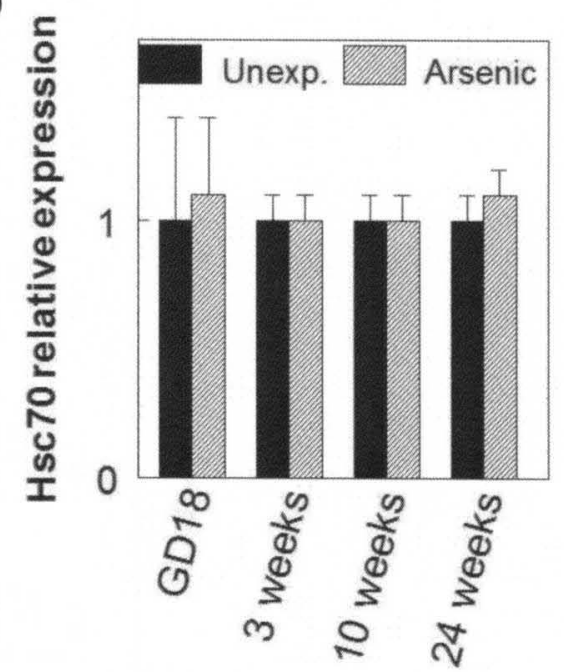

Figure 3.3. Western blot analyses of hepatic Hsp70 and Hsc70 expression during course of prenatal and postnatal development. Livers of control and arsenic-exposed mice at four stages of development (GD18, and 3, 10 and 24 weeks) were homogenized with either SDS lysis buffer or RIPA buffer as 
described in Materials and Methods. Western blot was performed to probe for Hsp70 and Hsc70. 14-3-3 $\beta$ was used as the loading and normalization control for GD18 samples, while GAPDH was used as the loading and normalization control for 3,10 and 24 week samples. ${ }^{*}=p<0.003$. Panel A: Representative western blot images of $\mathrm{Hsp} 70$ in livers of arsenic exposed and unexposed mice sacrificed on GD18, Day 21, Day 70 and Day 168. Panel B: Densitometric quantitation of $\mathrm{Hsp} 70$ at each stage of development. Panel C: Representative western blot images of $\mathrm{Hsc70}$ in livers of arsenic exposed and unexposed mice sacrificed on GD18, Day 21, Day 70 and Day 168. Panel D: Densitometric quantitation of $\mathrm{Hsc70}$ at each stage of development. 


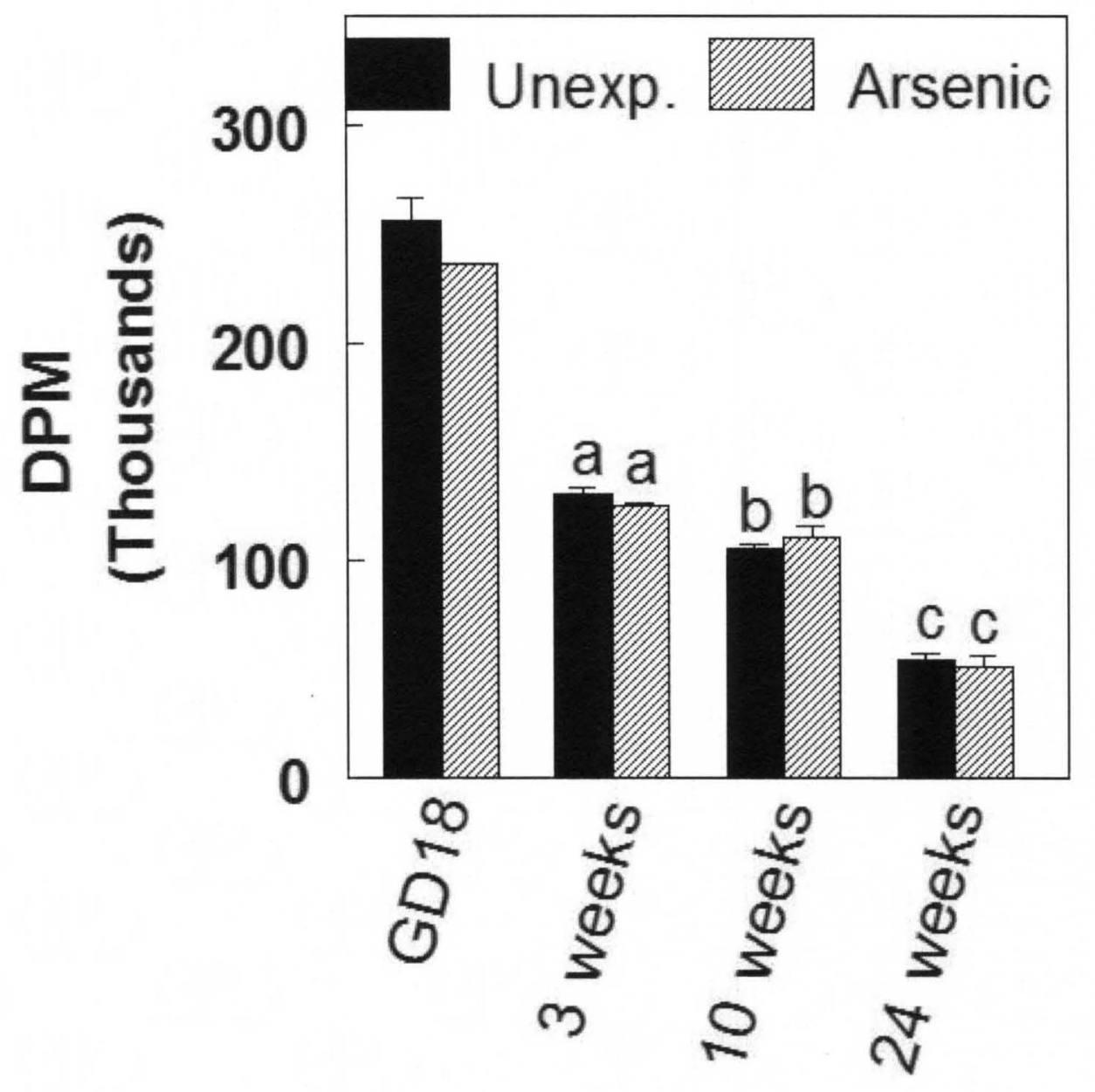

Figure 3.4. Analysis of global DNA methylation during course of prenatal and postnatal development, measured by methyl acceptance assay. Higher $\left[{ }^{3} \mathrm{H}\right]$ methyl incorporation by bacterial DNA methyltransferase into unmethylated cytosines corresponds to lower degree of global DNA methylation. $a=p<0.05$ compared to Day $0, b=p<0.05$ compared to Day 21 and $c=p<0.05$ compared to Day 70 . Data are mean \pm SEM. $n=6-9$ 


\section{Methylation status of the promoter region and CpG island of Hsp70}

The Methylation of DNA in the promoter region or within the body of the gene can alter the expression of the gene. I determined if the increased Hsp70 expression observed with prenatal arsenic exposure corresponded to differential DNA methylation induced by arsenic exposure. The $\mathrm{Hsp} 70 \mathrm{CpG}$ island is $2.5 \mathrm{~kb}$ long and spans through the promoter region and $66 \%$ of the body of the gene (Fig. 3.1). Hsp70 methylation was determined in livers of 10 week old mice by bisulfite sequencing of 5 regions spanning $1.9 \mathrm{~kb}$ of the $\mathrm{CpG}$ island (Fig. 3.1) as described in Materials and Methods. The methylation status of analyzed regions of hepatic $\mathrm{Hsp} 70 \mathrm{CpG}$ island which includes the promoter region is shown in Figure 3.5 A. The results are expressed as percentage $\mathrm{CpG}$ site methylation per region. The data reveal that the promoter region (R1) of $H s p 70$ is completely unmethylated in DNAs from both arsenic-exposed and unexposed mice. However, analysis of regions within the body of Hsp70 (R2 - R5) show differential methylation patterns, with region-specific hypo- and hypermethylation. In many instances, a CpG site is completely methylated or unmethylated (Fig. 3.5 B). Relative to controls, arsenic exposure significantly increased CpG site methylation of Region 3 ( $R 3$ spans +503 to +856 ). 


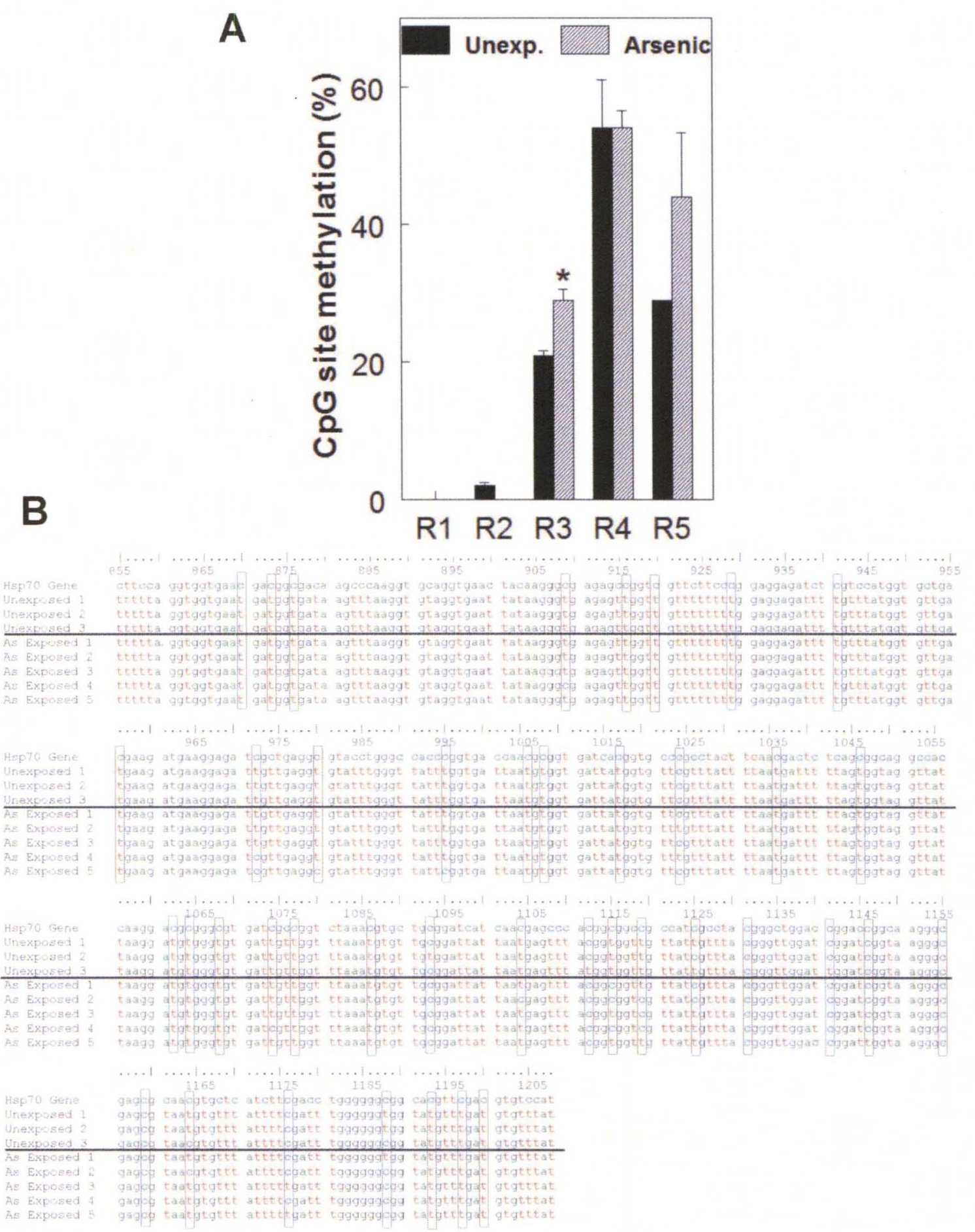

Figure 3.5. Analysis of $H s p 70$ promoter region and CpG island methylation.

Genomic DNA was isolated from livers of 10 week old arsenic-exposed and unexposed mice and $400 \mathrm{ng}$ was subjected to bisulfite treatment for the 
determination of $H s p 70$ methylation as described in Methods. Data are Mean \pm SEM. * $p<0.004$ Panel A: Quantitation of percentage CpG site methylation per region. Panel B: A representative sequence from R3 $(n=3-5)$ showing methylated and unmethylated $\mathrm{CpG}$ sites. Methylated cytosines are represented as dots in the boxes, while unmethylated cytosines appear as " $t$ ". 


\section{HSF1 and Nrf2 nuclear translocation and activation}

Hsf1 and Nrf2 are transcription factors which are major regulators of Hsp70 expression. The translocation of $\mathrm{Hsf1}$ and $\mathrm{Nrf2}$ from cytoplasm to nucleus is important for their activation in gene transcription. To determine if arsenic exposure was also having an upstream effect on transcription factors regulating Hsp70 expression, western blot analysis of cytosolic and nuclear Hsf1 and Nrf2 proteins was performed. Data revealed that a greater part of $\mathrm{Nrf2}$ is located in the cytosol, with very limited translocation to the nucleus (Fig. 3.6). Arsenic exposure did not alter the cytosolic levels of Hsf1 and $\mathrm{Nrf}$, nor did it increase nuclear translocation. The levels of Hsf1 in both cytosolic and nuclear fractions were very low and almost undetectable. Absence of nuclear translocation indicates Hsf1 and Nrf2 are not activated. These data suggest the mechanism of Hsp70 induction by arsenic exposure is by other transcription factors. 


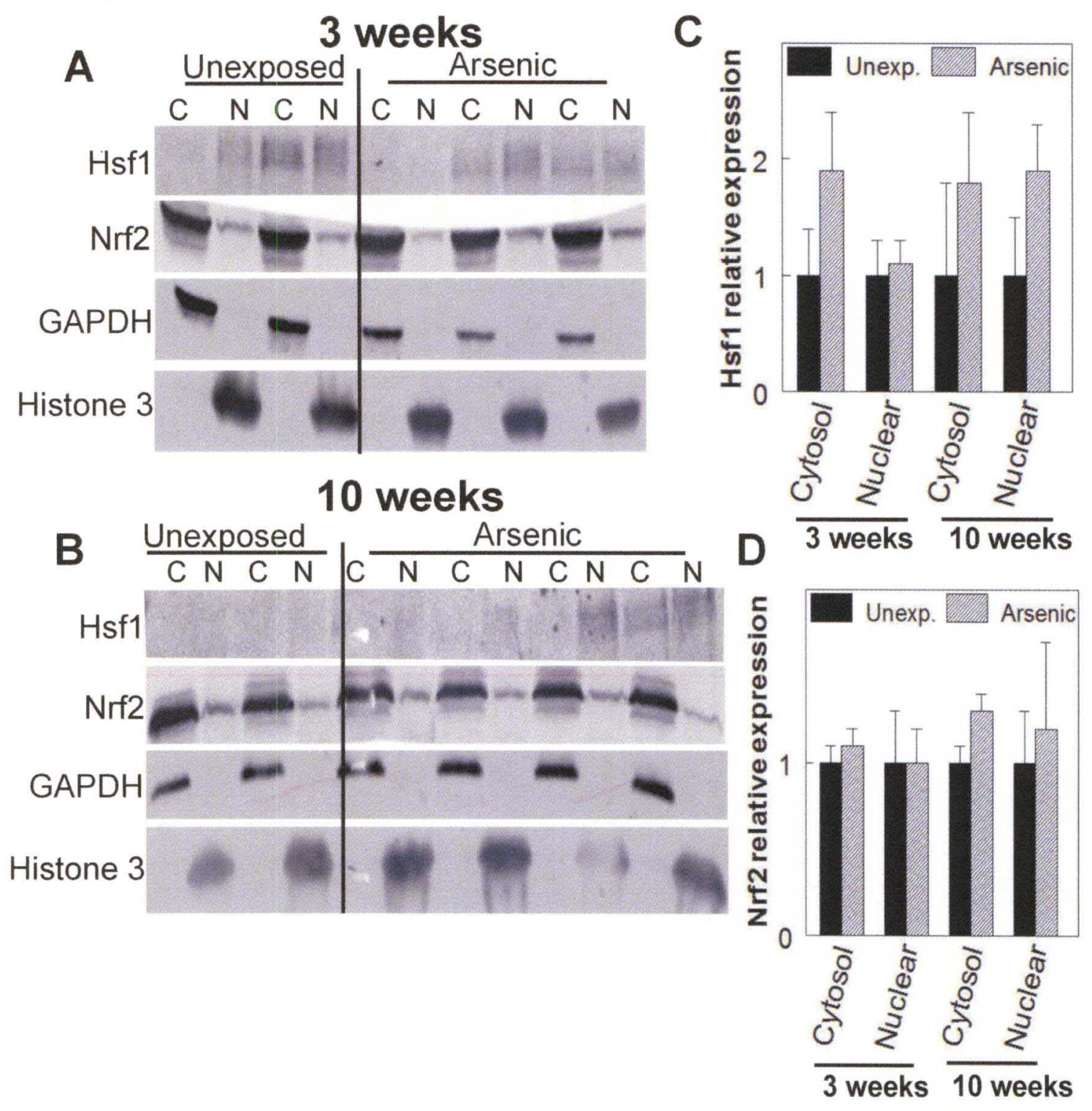

Figure 3.6. Western blot analysis of Hsf1 and Nrf2 cytosolic and nuclear

protein levels. Cytosolic and nuclear fractions were isolated from livers of 3 and 10 week old arsenic-exposed or unexposed mice as described in Materials and Methods. Western blot was performed to probe for Hsf1 and Nrf2. GAPDH was used as the normalization control for cytosolic proteins and to determine nuclear purity, while Histone 3 was used as the normalization control for nuclear proteins and to determine cytosolic purity. Panel A: Representative western blot images of 
cytosolic and nuclear Hsf1 and Nrf2 in livers of 3 week old arsenic-exposed and unexposed mice. Panel B: Representative western blot images of cytosolic and nuclear Hsf1 and Nrf2 in livers of 10 week old arsenic-exposed and unexposed mice. Panel C: Densitometric quantitation of cytosolic and nuclear Hsf1. Panel D: Densitometric quantitation of cytosolic and nuclear Nrf2 
Table 3.2. MiRNAs decreased by prenatal arsenic exposure and predicted to have sites on Hsp70 mRNA as predicted by miRWalk and other programs.

\begin{tabular}{|l|l|}
\hline MiRNA & Target region \\
\hline Mmu-miR-130a & $3^{\prime}$-UTR \\
\hline Mmu-miR-218 & CDS \\
\hline Mmu-miR-412 & CDS \\
\hline Mmu-miR-681 & \\
\hline
\end{tabular}




\section{Discussion}

Whereas Hsc70 is a constitutively expressed molecular chaperone, Hsp70 is a stress- inducible type which helps cells to resist stress by solubilizing denatured protein aggregates, facilitating the restoration of the function of renatured proteins, and transporting irreversibly damaged proteins to degradative organelles and proteasomes (Kiang and Tsokos, 1998). This study for the first time clearly demonstrate that prenatal exposure to inorganic arsenic results in delayed temporal postnatal induction of the stress inducible Hsp70 gene in livers of $\mathrm{ApoE}^{-/}$mice. Hsc70 expression did not change during any stage of postnatal development thus confirming it is not stress inducible. The Hsp70 expression increases several weeks after arsenic exposure is stopped and continues for several more weeks before returning to normal levels. The increased Hsp70 expression at ages 3 and 10 weeks following prenatal arsenic exposure indicates a temporal period of stress, and thus suggests a critical window during which time the mice are most susceptible to other environmental insults leading to atherosclerosis. These data suggest a low grade injury in which there is no detectable damage at the time of arsenic exposure, but the tissue becomes sensitized or primed for a greater detectable damage upon a second hit which comes later in life. This hypothesis is supported by the enhanced lipopolysaccharide-induced liver damage caused by chronic arsenic exposure (Arteel et al., 2008). Thus, the data in this current study suggest that Hsp70 expression is not sufficient to be used as a biomarker of arsenic exposure as proposed by some in vitro and vivo studies (Del Razo et al., 2001; Han et al., 
2005) owing to the absence of increased expression at the time of exposure. Absence of GD18 hepatic Hsp70 induction in our study is consistent with the findings of Petrick et al. (Petrick et al., 2009) who reported that microarray analysis of GD18 embryonic mouse lungs showed no alterations in Hsp70 expression following prenatal arsenic exposure. Other studies have reported increased Hsp70 expression in vivo following arsenic exposure. Hsp70 is reported to be induced in mouse liver by chronic low dose postnatal arsenic exposures (Andrew et al., 2007), and in lungs after acute subcutaneous injections of sodium arsenite and arsenate (Liu et al., 2001). Also, microarray analysis of adult $\mathrm{C} 3 \mathrm{H}$ mouse liver tumors revealed decreased Hsp70 mRNA expression by prenatal arsenic exposure (Liu et al., 2004). However, the decreased Hsp70 expression was not confirmed by RT-PCR or western blot. There is also growing evidence implicating Hsp70 in atherosclerosis (Lu and Kakkar, 2010). Stressed cells can actively release extracellular Hsp70 (Asea, 2007) which when present in extracellular membranes can activate macrophages to induce TNF- $\alpha$ expression (Vega et al., 2008), leading to increased inflammatory stimulus promoting atherogenesis. Importantly, Hsp70 expression is increased in the plasmas of patients with atherosclerosis (Wright et al., 2000; Zhu et al., 2003). However, it is still unclear whether circulating Hsp70 has a cytoprotective or cytotoxic role in atherosclerosis (Bielecka-Dabrowa et al., 2009).Taken as a whole, these observations suggest that the stressed hepatic cells in our mouse model may release excess Hsp70 into the circulation, thus contributing to the observed increased atherosclerosis. 
Arsenic exposure can alter epigenetic marks, especially causing DNA methylation alterations (Reichard and Puga, 2010). In the present study, prenatal arsenic exposure did not alter global DNA methylation postnatally during the course of development. This finding is consistent with the report of hypomethylation in GC-rich regions but not globally in hepatic DNA of newborn $\mathrm{C} 3 \mathrm{H}$ mice exposed to arsenic prenatal (Xie et al., 2007). The novelty of this study is that global DNA methylation during the course of pre- and postnatal development was determined. The findings are that global DNA methylation does not remain constant, but increases (DNA becomes hypermethylated) with age. Chronic postnatal arsenic exposure is reported to cause global DNA hypomethylation in livers of adult mice and is associated with arsenic-induced hepatocarcinogenesis (Chen et al., 2004). The apparent difference in global DNA methylation between my findings and that of Chen et al. can be attributed to the difference in arsenic exposure; brief prenatal arsenic exposure versus chronic postnatal exposure.

DNA methylation is an important epigenetic mechanism involved in altered gene expression. For example, prenatal arsenic exposure decreased the methylation of estrogen receptor- $\alpha$ promoter region of adult mouse liver leading to increased gene expression which may play a role in arsenic-induced hepatocellular carcinoma (Waalkes et al., 2004). Global DNA methylation does not predict what happens at gene-specific level. Thus, the role of DNA methylation as a potential mechanism underlying increased Hsp70 expression was determined. The results show that prenatal arsenic exposure did not alter $\mathrm{Hsp} 70$ promoter region 
methylation, but significantly increased methylation within the body of the gene, thus, indicating an epigenetic effect. The methylation pattern across the Hsp70 gene was also determined. The data show that $H s p 70$ promoter region is generally unmethylated and that the methylation density increases in the body of the gene, with some regions having higher methylation densities than others. It is reported that extensive $\mathrm{CpG}$ methylation of a $1.2 \mathrm{~kb}$ region spanning the $H s p 70$ transcription start site is associated with transcriptional silencing of Hsp70 genes in several mouse cell lines in which Hsp70 expression is not activated by heat shock (Gorzowski et al., 1995). This report suggests that the methylation status of $H s p 70$ promoter region can correlate with gene expression, with increased methylation associated with decreased gene expression and vice versa. However, this correlation between Hsp70 promoter region methylation status and gene expression is not seen in my animal model. This lack of methylation difference indicates that the underlying mechanism of Hsp70 induction is not due to decreased $H s p 70$ promoter region methylation.

Hsf1 and Nrf2 are the major characterized players involved in Hsp70 transcription. During cellular stress, Hsf1 becomes activated and translocates from the cytoplasm to the nucleus where it directly binds to the $H s p 70$ promoter region and induces transcription (Kiang and Tsokos, 1998). On the other hand, Nrf2 is a transcription factor that transcriptionally activates expression of antioxidant responsive genes. Nrf2 activation also is associated with nuclear translocation (Kobayashi and Yamamoto, 2005). Although Nrf2 does not directly target $H s p 70$, activation of $\mathrm{Nr} 2$ is reported to be associated with $\mathrm{Hsp} 70$ induction 
(Rinaldi Tosi et al., 2011). Hsf1 is reported to be the mechanism underlying increased Hsp70 expression following acute arsenic treatment in vitro (Kato et al., 1997; Khalil et al., 2006). However, the mechanism underlying arsenicinduced Hsp70 expression in vivo is not clearly understood, because the few reported in vivo studies did not determine the mechanism of increased Hsp70 expression. One study (Wijeweera et al., 2001) reports the involvement of AP-1 transcription factor activation and DNA binding in the induction of stress proteins including Hsp70 in precision-cut rat lung slices exposed to arsenic. I also determined whether arsenic may be causing an upstream effect in inducing Hsp70 expression. The mechanisms underlying delayed increased Hsp70 expression following prenatal arsenic exposure might be different from that of immediate gene induction following acute or chronic arsenic exposure. Immediate Hsp70 induction in response to stress is usually by traditional transcription factor activation which is a transient event. I thus propose that in addition to altered DNA methylation within the body of $H s p 70$, another potential mechanism of delayed Hsp70 induction in response to stress is the involvement of miRNA regulation. Prior microarray analyses of miRNA in 10 week old mice with or without prenatal arsenic exposure revealed that arsenic exposure decreased the expression of 15 miRNAs (States et al., 2009). Four out of the 15 decreased miRNAs (Table 3.2) have been predicted to have sites on Hsp70 mRNA 3'-untranslated region (UTR) and coding sequence (CDS) regions as predicted by miRWalk and other programs (http://www.ma.uniheidelberg.de/apps/zmf/mirwalk/). MiRNAs are short RNA molecules, about 23 
nucleotides long that are post-transcriptional regulators of gene expression. MiRNAs bind to complementary sequences on mRNAs, usually resulting in translational repression and gene silencing (Bartel, 2009). These data suggest that the decreased expression of miRNAs that target the Hsp70 mRNA results in increased Hsp70 mRNA stability, thus leading to increased protein levels in livers of arsenic-exposed mice. Future work will investigate regulation of the miRNAs.

In summary, the present study demonstrated that prenatal exposure to arsenic in drinking water results in delayed temporal induction of inducible type Hsp70 in the liver. Prenatal arsenic exposure did not alter global DNA methylation during postnatal development. The underlying mechanism of Hsp70 induction is not by transcription factor activation, but likely involves altered DNA methylation within the body of the gene. Other potential mechanisms such as increased microRNA stability might also be involved. These findings indicate that prenatal arsenic exposure causes a low grade injury and suggest that there is a critical window during which the liver is most sensitized to increased susceptibility to other environmental insults, thus predisposing to liver disease and accelerated atherosclerosis. 


\title{
CHAPTER IV
}

\section{DIFFERENTIAL HSP70, HSC70, GST-ALPHA AND TNF-A EXPRESSION IN HEPATOCYTES, KUPFFER CELLS, SINUSOIDAL ENDOTHELIAL CELLS AND STELLATE CELLS ISOLATED FROM APOE KNOCKOUT MICE EXPOSED TO ARSENIC PRENATAL}

\begin{abstract}
Introduction
Arsenic exposure alters expression of many genes in the liver which could contribute to the development of diseases. For example, the induction of hepatocellular cancer by prenatal arsenic exposure is associated with the altered expression of genes related to estrogen receptor alpha function, which could contribute to the development of cancer (Liu et al., 2006). Furthermore, in the prenatal arsenic-induced atherosclerosis mouse model, arsenic exposure differentially regulates gene expression in the liver as determined by microarray analysis of mRNA and miRNA of newborns and 10 week old mice (States et al., 2009). Age was the major factor for differential gene expression, with pathways involving heat shock protein 70 (Hsp70), heat shock cognate 70 (Hsc70) and tumor necrosis factor (TNF) increased by arsenic exposure in livers of 10 week old mice, thus suggesting a state of stress and pro-inflammation. Western blot analysis showed increased Hsp70 but not Hsc70 or TNF- $\alpha$ expression in 10
\end{abstract}


week old arsenic exposed mice (see Chapter II and III). However, despite the many studies that report the effects of arsenic exposure on hepatic gene expression, it is not yet determined how arsenic affects the expression of these genes in the different cell types that make up the liver. That is, if the arsenic effect on a particular gene is the same in all liver cell types, or arsenic has a preferential effect on a particular cell type.

The liver is a heterogeneous organ that is made up of different cell types which differ in functional characteristics. The major liver cell types are the parenchymal cells (PCs) (also known as hepatocytes, make up $70-80 \%$ of the liver mass) and the non-parenchymal cells (NPCs) (which are resident in or along the normal liver sinusoid, and participate in the function of the liver). The NPCs include 3 major cell types, the Kupffer cells, endothelial cells and stellate cells (Bouwens et al., 1992). The Kupffer cells are specialized macrophages resident in the liver that form part of the reticuloendothelial system. Kupffer cells function in endocytosis, antigen processing, secretion of bioactive factors and cytotoxicity. The sinusoidal endothelial cells (SEC) are characterized by fenestrations (pores) which regulate transport and exchange of materials between the blood and hepatocytes. Stellate cells (SC) are vitamin A-storing cells and constitute 5-8 \% of total liver cells. In normal liver, SC are in a quiescent state, but become activated during liver damage to produce extracellular matrix and collagen. In this study, the expression of selected genes in the different liver cell types was determined; i.e. which liver cell types are expressing these genes and how arsenic exposure alters gene expression. 


\section{Materials and Methods}

\section{Materials}

Pronase E was purchased from Merck: EMD (Gibbstown, NJ), Collagenase and DNase were purchased from Roche Diagnostics (Indianapolis, IN), and Nycodenz was purchased from AXIS-SHIELD (Norton, MA)

\section{Animals and treatment}

$\mathrm{ApoE}^{-/ \mathrm{C}} \mathrm{C} 5 \mathrm{BL} / 6 \mathrm{~J}$ mice were housed in a pathogen-free barrier facility accredited by the Association for Assessment and Accreditation of Laboratory Animal Care, and procedures were approved by the local Institutional Animal Care and Use Committee. Pregnant mice were given tap water (for controls) or water containing $85 \mathrm{mg} / \mathrm{L} \mathrm{NaAsO}{ }_{2}$ (49 ppm arsenic) on gestation days (GD) 8 - GD18. Their male offspring were kept until 16-17 weeks old and maintained on a standard diet.

\section{Liver perfusion and cell type isolation}

Mice were anesthetized with ketamine/xylazine $\mathrm{HCl}$ solution $(80 / 12 \mathrm{mg} / \mathrm{kg}$ i.m.). A cross incision was made in the abdomen of the mouse and $20 \mathrm{G}$ catheter was inserted into the inferior vena cava (IVC) and the vessel was cannulated. The chest cavity was opened to induce backflow of blood. The liver was perfused with EGTA-solution (137 mM NaCl, $5.4 \mathrm{mM} \mathrm{KCl}, 0.6 \mathrm{mM} \mathrm{NaH}_{2} \mathrm{PO}_{4}, 0.8 \mathrm{mM} \mathrm{Na}_{2} \mathrm{HPO}_{4}$, $10 \mathrm{mM}$ HEPES, $4.2 \mathrm{mM} \mathrm{NaHCO}_{3}, 0.5 \mathrm{mM}$ EGTA, and $4.5 \mathrm{mM}$ glucose, $\mathrm{pH} 7.4$ ) at a rate of $5 \mathrm{~mL} / \mathrm{min}$. The portal vein was cut and cannulated immediately, and 
the suprahepatic IVC was clamped using a vascular clamp. Liver perfusion with EGTA solution continued until the liver became pale in color. The liver was perfused with pronase $\mathrm{E}$ solution $(40 \mathrm{mg} / 100 \mathrm{~mL} \mathrm{SC}-2$ solution $(137 \mathrm{mM} \mathrm{NaCl}$, $5.4 \mathrm{mM} \mathrm{KCl}, 0.6 \mathrm{mM} \mathrm{NaH}_{2} \mathrm{PO}_{4}, 0.8 \mathrm{mM} \mathrm{Na}_{2} \mathrm{HPO}_{4}, 10 \mathrm{mM}$ HEPES, $4.2 \mathrm{mM}$ $\left.\left.\mathrm{NaHCO}_{3}, 3.8 \mathrm{mM} \mathrm{CaCl} 2.2 \mathrm{H}_{2} \mathrm{O}, \mathrm{pH} 7.4\right)\right)$ for $5 \mathrm{~min}$. Perfusion with pronase $\mathrm{E}$ solution was followed by 7-8 min perfusion with collagenase D solution ( 50 $\mathrm{mg} / 120 \mathrm{~mL} \mathrm{SC}-2$ solution). A heat lamp was used throughout the perfusion process. The liver was carefully removed and placed in a $100 \mathrm{~mm}$ petri dish containing SC-2 solution on ice. The gall bladders were removed and each liver was separately minced well to separate cells. Cells were transferred into sterile Erlenmeyer flask and $25 \mathrm{~mL}$ warm $\left(40^{\circ} \mathrm{C}\right)$ solution "D" $(100 \mathrm{~mL} \mathrm{SC}-2+55 \mathrm{mg}$ collagenase $+50 \mathrm{mg}$ pronase $+1 \mathrm{~mL}$ DNase I solution $(2 \mathrm{mg} / \mathrm{mL}$ Grey's balanced salt solution B (GBSS/B)) was added per liver. Grey's balanced salt solution $\mathrm{B}$ (GBSS/B) consisted of $137 \mathrm{mM} \mathrm{NaCl}, 5 \mathrm{mM} \mathrm{KCl}, 1 \mathrm{mM} \mathrm{MgCl} 2 \cdot 6 \mathrm{H}_{2} \mathrm{O}$, $0.3 \mathrm{mM} \mathrm{MgSO}_{4} .7 \mathrm{H}_{2} \mathrm{O}, 0.4 \mathrm{mM} \mathrm{Na}_{2} \mathrm{HPO}_{4}, 0.2 \mathrm{mM} \mathrm{KH}_{2} \mathrm{PO}_{4}, 5.5 \mathrm{mM}$ glucose, 2.7 $\mathrm{mM} \mathrm{NaHCO} 3,1.5 \mathrm{mM} \mathrm{CaCl}_{2} .2 \mathrm{H}_{2} \mathrm{O}$, at pH 7.35. The cells were incubated at $37^{\circ} \mathrm{C}$ for 25 minutes with frequent shaking and the digested liver was filtered through a sterile nylon mesh sheet $(120 \mu \mathrm{m}) /$ Cell strainer (BD Falcon, $70 \mu \mathrm{m})$. Samples of 50-100 uL were removed as total cell fraction and frozen. Cells were centrifuged at $50 \times \mathrm{g}$ for $5 \mathrm{~min}$ at $4^{\circ} \mathrm{C}$ to separate the parenchymal cells (PCs) from the nonparenchymal cells (NPCs). The supernatant containing NPCs was removed and placed on ice, while the hepatocyte pellet was resuspended in GBSS/B solution and washed twice at $50 \times \mathrm{g}$ for $5 \mathrm{~min}$ at $4^{\circ} \mathrm{C}$. Hepatocyte pellets were aliquoted 
and stored frozen. Each NPC fraction was transferred to $50 \mathrm{~mL}$ Falcon tubes and centrifuged at $550 \times g$ for $10 \mathrm{~min}$ at $4^{\circ} \mathrm{C}$. The supernatant was discarded except 5 $\mathrm{mL}$. The pellet was resuspended and aliquots were taken as total NPCs fraction. Five $\mathrm{mL}$ GBSS/B containing $120 \mu \mathrm{L}$ DNAse I was added to each NPC suspension. Suspensions from 2-4 mice of the same exposure group were pooled in one $50 \mathrm{~mL}$ tube. GBSS/B was added up to $50 \mathrm{~mL}$ and NPCs were centrifuged at $550 \times \mathrm{g}$ for $10 \mathrm{~min}$ at $4^{\circ} \mathrm{C}$. The supernatant was discarded except 5 $\mathrm{mL}$. An additional $5 \mathrm{~mL}$ of GBSS/B containing $120 \mathrm{uL}$ of DNase I was added and pellets were resuspended. GBSS/B was added up to $30 \mathrm{~mL}$. NPCs were subsequently separated by nycodenz gradient centrifugation. Two Nycodenz gradients were poured in $5 \mathrm{~mL}$ tubes. Thirty \% Nycodenz stock was made by adding $11 \mathrm{~g}$ Nycodenz in $33 \mathrm{~mL}$ of GBSS/A $\left(5 \mathrm{mM} \mathrm{KCl}, 1 \mathrm{mM} \mathrm{MgCl} 2.6 \mathrm{H}_{2} \mathrm{O}, 0.3\right.$ $\mathrm{mM} \mathrm{MgSO}{ }_{4} .7 \mathrm{H}_{2} \mathrm{O}, 0.4 \mathrm{mM} \mathrm{Na}_{2} \mathrm{HPO}_{4}, 0.2 \mathrm{mM} \mathrm{KH}_{2} \mathrm{PO}_{4}, 5.5 \mathrm{mM}$ glucose, $2.7 \mathrm{mM}$ $\mathrm{NaHCO}_{3}, 225 \mathrm{mg} / \mathrm{L} \mathrm{CaCl}_{2} .2 \mathrm{H}_{2} \mathrm{O}, \mathrm{pH} 7.35$ ) and the solution was filtered through $0.22 \mu \mathrm{m}$ filter. Nycodenz $17.5 \%$ was made by mixing $13.5 \mathrm{~mL} 30 \%$ nycodenz + $10 \mathrm{~mL}$ GBSS/B, while $10.8-11 \%$ Nycodenz was made by mixing $30 \mathrm{~mL}$ cell pellets with $13.5 \mathrm{~mL}$ of $30 \%$ Nycodenz. To pour the Nycodenz gradients, the cells $(20-22 \mathrm{~mL}$ ) were layered first, followed by $11-12 \mathrm{~mL}$ of $17.5 \%$ Nycodenz from the bottom. Lastly, 2.5-3 mL of GBSS/B was carefully added on top of the cell layers. The tubes were centrifuged at $1450 \times \mathrm{g}$, for $20 \mathrm{~min}$ at $20^{\circ} \mathrm{C}$ with the break set off (i.e deceleration set to 1 and acceleration to about 5). Stellate cells $(\approx 3-5 \mathrm{~mL} / 15 \mathrm{~mL}$ tube) were collected from the white layer under the clear layer of GBSS/B solution using a $5 \mathrm{~mL}$ pipette and transferred to new $50 \mathrm{~mL}$ tube. The 
layer (interface) beneath the white layer containing Kupffer cells $(\mathrm{KC})$ and sinusoidal endothelial cells (SEC) was collected $(20-25 \mathrm{~mL})$ and transferred to new $50 \mathrm{~mL}$ tubes. The pellet at the bottom contained red blood cells. GBSS/B was added up to $50 \mathrm{~mL}$ overall volume to stellate cells (pooled cells from the two $15 \mathrm{~mL}$ tubes) and centrifuged at $550 \times \mathrm{g}$ for $10 \mathrm{~min}$ at $4^{\circ} \mathrm{C}$. Cells were resuspended in $1 \mathrm{~mL}$ GBSS/B, transferred into $1 \mathrm{~mL}$ tubes and centrifuged again to collect pellets. To the fraction containing KC and SEC, GBSS/B was added to $50 \mathrm{~mL}$ mark to dilute the Nycodenz. Tubes were centrifuged at $900 \times \mathrm{g}$ for $10 \mathrm{~min}$ at $4^{\circ} \mathrm{C}$, and supernatant was removed. Cell pellets were resuspended in $2 \mathrm{~mL}$ of RPMI 1640 and plated in $35 \mathrm{~mm}$ petri dish to separate the KCs from SECs. Plates were incubated for $20 \mathrm{~min}$ at $37^{\circ} \mathrm{C}, 95-100 \%$ humidity and $5 \% \mathrm{CO}_{2}$ for Kupffer cells to adhere to plastic. After incubation, supernatant containing SEC was removed and pooled in a $15 \mathrm{~mL}$ tube. Adhered Kupffer cells were washed with GBSS/B once and cells were collected in $1 \mathrm{~mL}$ tube and centrifuged to obtain pellets. SECs were centrifuged at $900 \times g$ for $10 \mathrm{~min}$ at $4^{\circ} \mathrm{C}$. Supernatant was removed and SEC pellet resuspended in $1 \mathrm{~mL}$ GBSS/B and centrifuged to obtain pellets. Quality control was performed for hepatocytes by light microscopy, and stellate cells by fluorescent microscopy. All cells were stored frozen at $-80^{\circ} \mathrm{C}$ for further studies

\section{Isolation of total proteins from isolated liver cell types}

Isolated liver cell fractions (total cell fractions, total NPCs, hepatocytes, KCs, SECs and SCs) were sonicated in SDS lysis buffer (10 mM Tris-HCL pH7.4, 1 
$\mathrm{mM}$ EDTA, $0.1 \%$ SDS, $1 \mathrm{mM}$ PMSF, $1 \mu \mathrm{g} / \mathrm{mL}$ aprotinin, $1 \mu \mathrm{g} / \mathrm{mL}$ leupeptin, and $1 \mu \mathrm{g} / \mathrm{mL}$ pepstatin and phosphatase inhibitor). Cell lysates were centrifuged at $14,000 \times g$ for $30 \mathrm{~min}$ at $4{ }^{\circ} \mathrm{C}$. The supernatant was transferred into a new tube and protein concentrations were determined with the Bio-Rad Bradford protein assay (Bio-Rad, Hercules, CA)

\section{Western blot analysis}

Proteins $(20 \mu \mathrm{g})$ were separated by SDS-PAGE. Proteins were transferred to a nitrocellulose membrane, and blocked with $5 \%$ non-fat dry milk to prevent nonspecific antibody binding. Membranes were incubated with primary antibodies including mouse monoclonal $\mathrm{Hsp} 70$ and rat monoclonal $\mathrm{Hsc70}$ antibodies (1:1000, overnight at $4{ }^{\circ} \mathrm{C}$; Enzo Life Sciences International, Inc., Plymouth Meeting, PA); rabbit GST- $\alpha(1: 5000,1 \mathrm{~h}$ at RT; a gift from Dr. Russel Prough at the University of Louisville); and rabbit polyclonal TNF- $\alpha$ antibody (1:1000 overnight at $4{ }^{\circ} \mathrm{C}$; Cell Signaling Technology Inc., Danvers, MA).; and rabbit polyclonal TNF- $\alpha$ (1:1000 overnight at $4{ }^{\circ} \mathrm{C}$; Cell Signaling Technology Inc., Danvers, MA). Membranes were incubated with corresponding mouse, rabbit, and rat secondary antibodies bound to HRP. The membranes were analyzed by ECL plus substrate (GE Healthcare Bio-Sciences Corp., Piscataway, NJ). Signals on ECL plus membranes were visualized directly on a Storm Phosphoimager in blue flourescence mode (Molecular Dynamics, Sunnyvale, CA). Protein bands were quantitated using the Image Quant software. 


\section{Statistical analysis}

Data are expressed as mean \pm SEM. Comparisons between groups were performed using student's t-test. 


\section{Results}

\section{Effects of prenatal arsenic exposure on heat shock protein expression in isolated liver cell types}

I have previously shown (in chapter III) that prenatal arsenic exposure causes a delayed temporal increase in hepatic inducible Hsp70 expression during the course of postnatal development of $\mathrm{ApoE}^{-/-}$mice. The increased expression was observed at 3 and 10 weeks of age, but returned to normal control levels at 24 weeks. Conversely, the expression of constitutive $\mathrm{Hsc} 70$ was not altered by arsenic exposure during the course of postnatal development. However, it is unknown which liver cell types express these heat shock proteins. Therefore, in this study, I determined the expression of Hsp70 and Hsc70 in liver cell types (PCs (hepatocytes) and NPCs (KC, SEC, and SC) isolated from $16-17$ week old $\mathrm{ApoE}^{-/-}$mice following prenatal arsenic exposure. The results discussed here are those obtained from hepatocyte fractions and separated individual NPCs. I could not obtain data for the total cell fractions and total NPCs because these samples were fast degrading, and thus unreliable. The results (Fig. 4.1) show that whereas the inducible Hsp70 is cell type-specific and expressed only in the parenchymal cells, the constitutive Hsc70 is expressed in both parenchymal and non-parenchymal cells. However, prenatal arsenic exposure did not alter the expression of Hsp70 at 16-17 weeks of age. Conversely, the expression of Hsc70 was significantly decreased in arsenic-exposed PCs $(p<0.01)$ at $16-17$ 

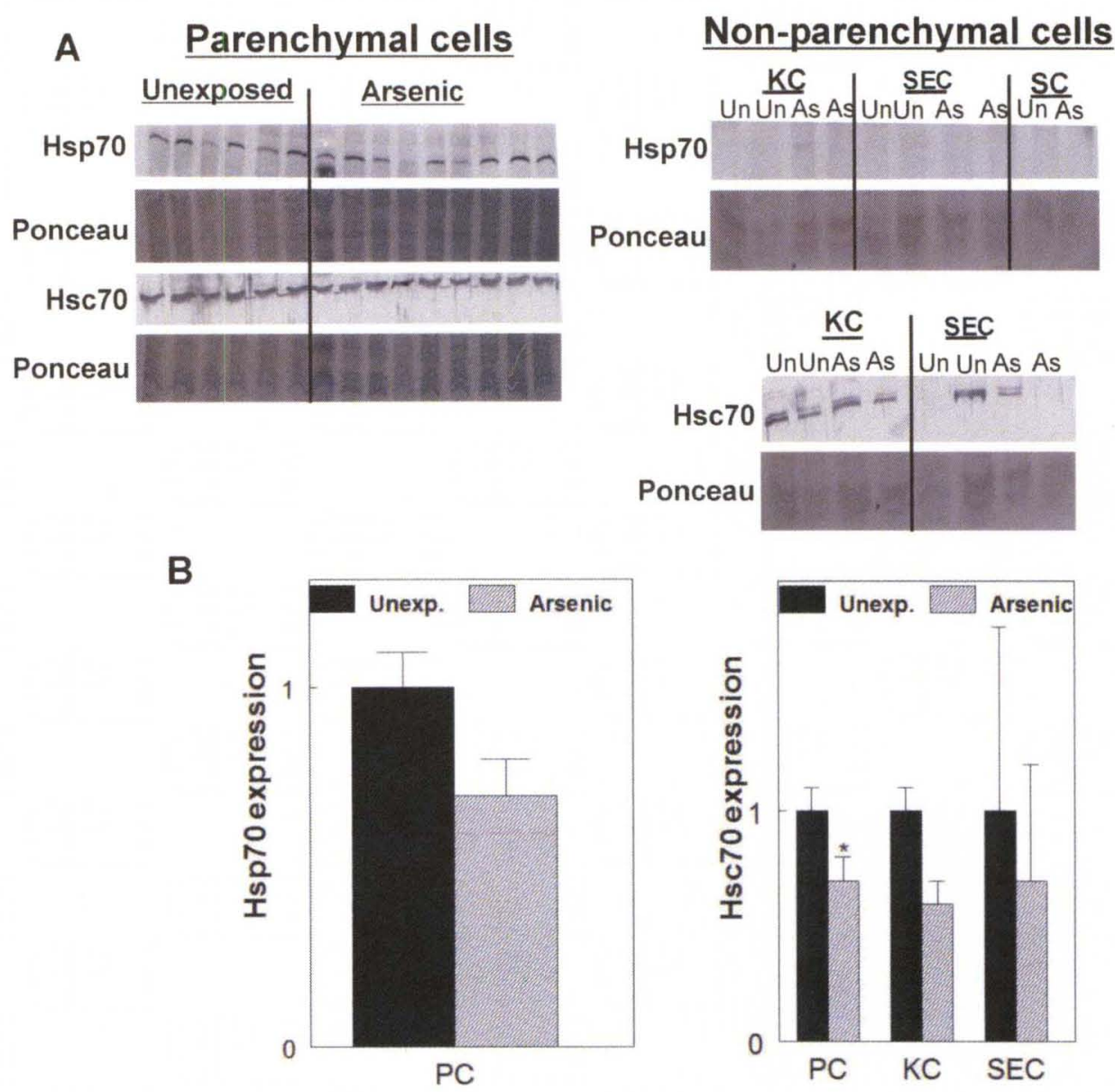

Figure 4.1. Effects of prenatal arsenic exposure on heat shock proteins in isolated liver cell types. Isolated liver cell types from perfused livers of 16-17 week old mice following prenatal arsenic exposure were lysed in SDS lysis buffer for total protein isolation. Western blot analysis was performed to probe for Hsp70 and Hsc70. Data are mean \pm SEM, $n=6-9 .{ }^{*}=p<0.01$ Error bars represent SEM of samples analyzed from the same exposure group. Note that perfused livers from 2-4 mice were pooled to obtain each sample of Kupffer cells (KC), sinusoidal endothelial cells (SEC) and stellate cells (SC). Panel A: Representative western blot images. Panel B: Densitometric quantitation of Hsp70 and Hsc70. 
weeks of age. Hsc70 expression was also decreased in NPCs although not statistically significant.

Effects of prenatal arsenic exposure on antioxidant responsive genes in isolated liver cell types

I also determined the effect of prenatal arsenic exposure on glutathione-stransferase (GST) alpha expression which is an antioxidant responsive gene. The results (Fig. 4.2) show that GST-alpha expression is also cell type-specific, with expression occurring only in parenchymal cells and not in non-parenchymal cells. However, prenatal arsenic exposure did not alter the expression of GSTalpha at 16-17 weeks of age.

Effects of prenatal arsenic exposure on inflammatory cytokines in isolated liver cell types

TNF-alpha is a pro-inflammatory cytokine. Therefore, effect of prenatal arsenic exposure on TNF-alpha was determined. My first observation was that TNFalpha is expressed only in NPCs and not in PCs (Fig. 4.3). In addition, TNF-alpha expression was higher in Kupffer cells than in the sinusoidal endothelial cells, and much lower in stellate cells. Secondly, prenatal arsenic exposure did not alter the expression of TNF-alpha in any of the cell types at 16-17 weeks of age. 


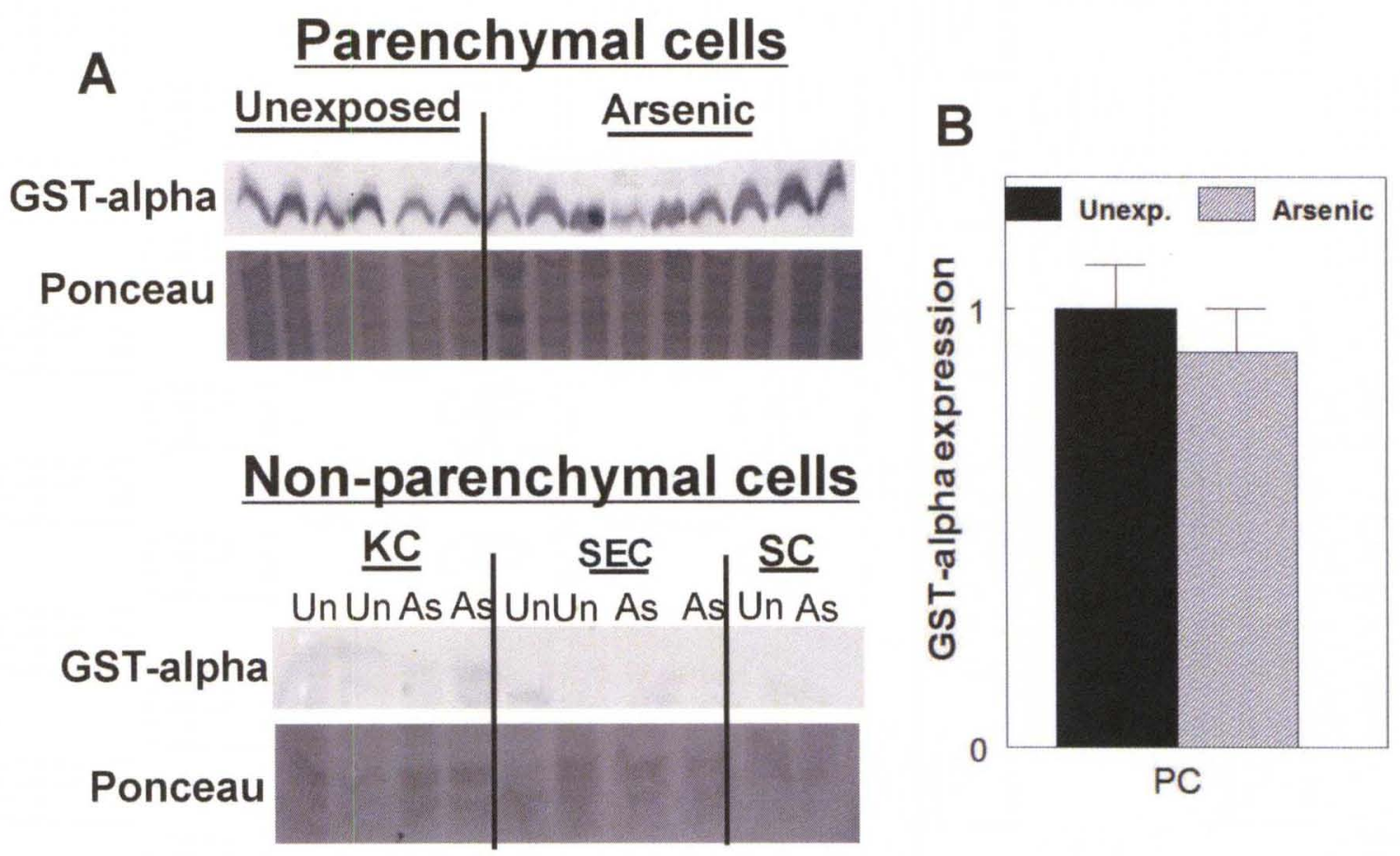

Figure 4.2. Effects of prenatal arsenic exposure on oxidative stress response in isolated liver cell types. Isolated liver cell types from perfused livers of 16-17 week old mice following prenatal arsenic exposure were lysed in SDS lysis buffer for total protein isolation. Western blot analysis was performed to probe for GST-alpha. Data are mean \pm SEM, $n=6-9$. Error bars represent SEM of samples analyzed from the same exposure group. Note that perfused livers from 2-4 mice were pooled to obtain each sample of Kupffer cells $(K C)$, sinusoidal endothelial cells (SEC) and stellate cells (SC). Panel A:

Representative western blot images. Panel B: Densitometric quantitation of GSTalpha. 

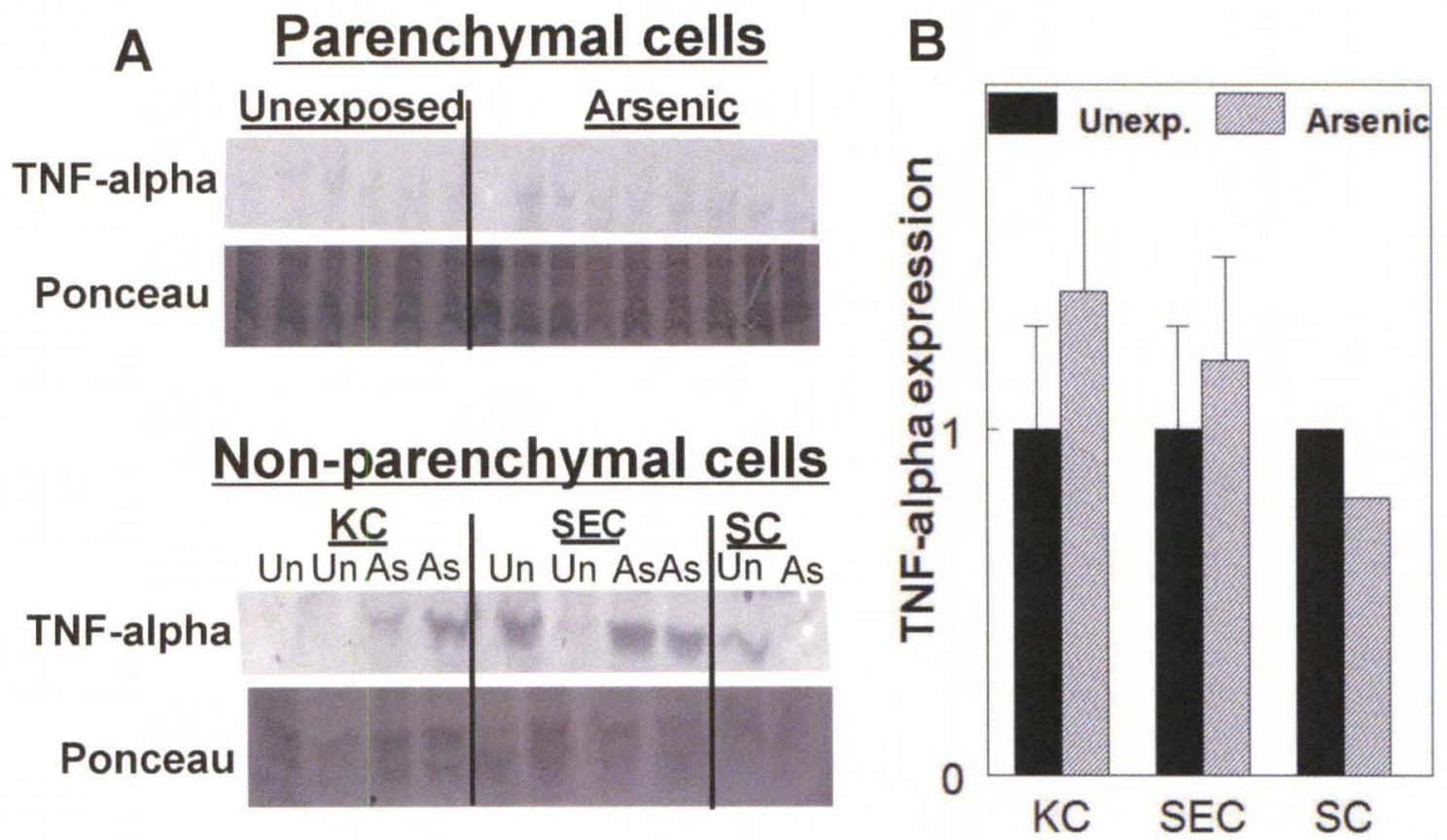

Figure 4.3. Effects of prenatal arsenic exposure on inflammation in isolated liver cell types. Isolated liver cell types from perfused livers of 16-17 week old mice following prenatal arsenic exposure were lysed in SDS lysis buffer for total protein isolation. Western blot analysis was performed to probe for TNF-alpha. Data are mean \pm SEM, $n=6-9$. Error bars represent SEM of samples analyzed from the same exposure group. Note that perfused livers from 2-4 mice were pooled to obtain each sample of Kupffer cells $(\mathrm{KC})$, sinusoidal endothelial cells (SEC) and stellate cells SC). Panel A: Representative western blot images.

Panel B: Densitometric quantitation of TNF-alpha. 


\section{Discussion}

The liver is a heterogeneous organ consisting of different cell types, including PC (hepatocytes) and NPC. The major sub-cell types of NPC include KC, SEC and SC. The liver's primary role in detoxification takes place within the PCs, whereas the NPCs provide physical and biochemical structure to the liver. Although there are several reports of altered gene expression in the liver in response to toxic agents including arsenic, there is little knowledge about which liver cell types are expressing these genes. In addition, it is unknown how the different liver cell types are affected during toxicity. The effects of prenatal arsenic exposure on the hepatic expression of $\mathrm{Hsp} 70$ and $\mathrm{Hsc70}$ during the course of postnatal development (GD18, and 3 week, 10 and 24 week of age) in $\mathrm{ApoE}^{-l-}$ mice were shown in Chapter III. It was shown that prenatal arsenic exposure did not alter Hsp70 expression at GD18 (when arsenic exposure is removed), but induced Hsp70 expression at 3 and 10 weeks of age. However, at 24 weeks of age, Hsp70 expression returned to control levels. Conversely, the expression of Hsc70 was not altered at any of the ages studied. Thus, in this study, I determined the expression of these heat shock proteins in liver cell types isolated from perfused livers of mice exposed to arsenic prenatal. My results show that Hsp70 is expressed only in the hepatocytes and was not altered by arsenic exposure at age 16 weeks. Conversely, Hsc70 is expressed in all liver cell types, and expression was decreased in hepatocytes by arsenic exposure at age 16 weeks. These data are different from my previous observations of the expression of the proteins at different life stages. 
The reason for these differences can be attributed to the difference in the ages studied. These new data indicate that the 16 weeks age fell in the descending part of the Hsp70 expression curve. Furthermore, the difference in Hsc70 data also shows that time or age is an important factor when studying toxicity. It is possible that the reduced expression of $\mathrm{Hsc70}$ resulted secondarily from the hepatic injury caused by prenatal arsenic exposure. A similar observation was reported in an experimental endotoxic shock model where hepatic Hsc70 expression was decreased when D-galactosamine-sensitized mice were exposed to lipopolysaccharide (Morikawa et al., 1998). The expression of Hsc70 observed in all liver cell types is not surprising since $\mathrm{Hsc70}$ is a molecular chaperone that is constitutively expressed in cells. Under physiological conditions, Hsc70 functions in regulating protein folding, protein translocation across membranes and degradation of aged proteins (Kiang and Tsokos, 1998). Thus, Hsc70 expression occurs in all liver cell types since all cells make proteins. Conversely, Hsp70 is a stress-response protein whose expression is induced when cells are stressed (e.g. by heat shock, toxic metals and oxidative stress). Expression of Hsp70 in only hepatocytes suggests that these are the cells that respond to stress when the liver is exposed to toxic agents.

Arsenic exposure is also known to result in oxidative stress, leading to the upregulation of antioxidant responsive genes. GSTs are antioxidant responsive proteins which function in the detoxification of endogenous compounds and xenobiotics. GSTs conjugate these compounds to reduced glutathione and facilitate their excretion from the body. The current study shows that GST-alpha 
is expressed only in the hepatocytes and not in NPCs. Furthermore, prenatal arsenic exposure did not alter the expression of GST-alpha at 16-17 weeks of age, which is different from increased GST-alpha activity in livers of mice chronically exposed to arsenic (Santra et al., 2000). This difference can be attributed to the fact that I looked at GST-alpha protein levels long after the exposure rather than measured activity following a chronic exposure. The hepatocyte-specific expression of GST-alpha is consistent with the fact that the hepatocytes perform the detoxification of xenobiotics in the liver.

Chronic arsenic exposure is reported to increase hepatic TNF-alpha and IL-6 expression associated with liver damage (Das et al., 2005; Wu et al., 2008). Prior work showed that prenatal arsenic exposure increased tumor necrosis factor pathway as determined by microarray analysis of miRNA and mRNA of livers of 10 week old mice (States et al., 2009), thus suggesting a state of proinflammation. Confirmation of the microarray data by western blot analysis (see Chapter II) showed that hepatic TNF-alpha expression was not altered by prenatal arsenic exposure at 10 weeks of age. Thus, it was determined whether the expression of TNF-alpha is differentially affected in the liver cell types isolated from perfused livers of 16-17 week old mice with prenatal arsenic exposure. The data show that TNF-alpha is expressed only in the NPCs, with Kupffer cells showing the highest expression, and stellate cells the lowest. Furthermore, prenatal arsenic exposure did not significantly increase the expression of TNF-alpha at 16-17 weeks of age which is consistent with the data obtained in Chapter II. Therefore, these data suggest that the livers of prenatally 
arsenic-exposed mice are not in a state of pro-inflammation at 10 or 16-17 weeks. Kupffer cells are the principal cells that mediate inflammatory responses in the liver, and have been reported to contribute to injury. These data explain the lack of LPS response observed in Chapter II. Activated Kupffer cells release several mediators including TNF-alpha which can act directly on hepatocytes to cause cell death, or indirectly through activation of other cells (Roberts et al., 2007). Sinusoidal endothelial cells and stellate cells are also reported to secrete cytokines (Bouwens et al., 1992).

In summary, this study has shown that Hsp70 is expressed only in the hepatocytes and its expression is not altered by prenatal arsenic exposure at 1617 weeks of age. On the other hand, Hsc70 is expressed in all liver cell types, and its expression is decreased by prenatal arsenic exposure in the hepatocytes of 16-17 week old mice. GST-alpha is expressed only in the hepatocytes, and its expression is not affected by prenatal arsenic exposure. Lastly, TNF-alpha is expressed only in the non-parenchymal cells, and prenatal arsenic exposure did not affect its expression at 16-17 weeks of age. Collectively, based on my experimental data and other reported studies, it is now clear that the deleterious effects of arsenic exposure depends on many factors, including exposure levels, exposure types, and time point or age studied. Therefore, it is important to consider critically all the above-mentioned factors when studying arsenic toxicity in animal models. 


\section{CHAPTER V}

\section{PRENATAL ARSENIC EXPOSURE AT LOW EXPOSURE LEVELS INCREASES ATHEROSCLEROTIC LESION FORMATION AND PLASMA INFLAMMATORY CYTOKINES/CHEMOKINES RELATED TO CARDIOVASCULAR DISEASE}

\section{Introduction}

Prior studies demonstrated that prenatal arsenic exposure in drinking water at an exposure level of $49 \mathrm{ppm}$ arsenic accelerated atherosclerosis in $\mathrm{ApoE}^{-/-}$mice, even without high fat diet which is usually requisite for early atherosclerosis in this strain (Srivastava et al., 2007). The 49 ppm arsenic exposure reflects exposures in populations with high arsenic levels. It still remains unclear if prenatal arsenic exposure can induce atherosclerosis in populations with low arsenic levels. For postnatal exposures, exposures as low as $1 \mathrm{ppm}$ arsenic (Srivastava et al., 2009) and 250 ppm arsenic (Lemaire et al., 2011) have been reported to increase atherosclerosis. It is thus necessary to determine if there is a threshold dose for the induction of atherosclerosis by prenatal arsenic exposure. Gestation is a period of sensitivity to initiation of adult atherosclerosis. However, it is likely that humans would have full life exposure. Our transplacental protocol of exposing pregnant $\mathrm{ApoE}^{-/}$dams to inorganic arsenic (49 ppm arsenic) 
in drinking water from gestation days 8 to 18 does not duplicate typical human exposure. The predictive adaptive response was a term coined by Gluckman and Hanson (Gluckman and Hanson, 2004) for the phenomenon in which a fetus responds to changes in its intrauterine environment by making adaptations to improve its immediate chances of survival. These adaptations are often reversible, but can be irreversible if the environmental changes persist. In this way, the fetus prepares itself for life in an extrauterine environment, e.g. low food availability or high levels of stress (de Boo and Harding, 2006). If the predicted environment is different from the actual environment into which the fetus is born, it may result in disease. Thus, based on the predictive adaptive response phenomenon, it is unknown whether exposure to arsenic prenatally will protect or enhance atherosclerosis promoted by arsenic exposure.

Despite the clear epidemiologic links between arsenic and an increased risk of atherosclerosis, the mechanisms by which arsenic enhances atherosclerosis are unclear. Atherosclerosis is a multi-factorial and complex disease process. Accumulating evidence from many studies indicates inflammation plays a central role in atherosclerotic plaque formation (see Chapter I).

Thus, in this study, the effect of lower exposure levels of arsenic on atherosclerosis was examined. In addition, the effects of "whole-life" arsenic exposures in the development of atherosclerosis was investigated by determining whether prenatal exposure protects against or enhances later life exposures. Lastly, the pro-atherogenic effects of arsenic on inflammation and circulating Hsp70 were also determined. 


\section{Materials and Methods}

\section{Animal housing and treatment protocols}

$A p o E^{-t}$ mice were housed and bred under pathogen-free conditions in controlled temperature and $12 \mathrm{~h}$ light $/ 12 \mathrm{~h}$ dark cycle following the guidelines of the Association for the Accreditation of Laboratory Animal Care. Prior to treatment, all mice were maintained on standard chow diet and tap water as previously described (Chapter II). Studies were performed under protocols approved by the University of Louisville Institutional Animal Care and Use Committee.

In one group, pregnant mice were maintained on tap water (controls) or tap water containing $8.5 \mathrm{mg} / \mathrm{L}$ (4.9 ppm arsenic) or $1.7 \mathrm{mg} / \mathrm{L}$ (1 ppm arsenic) $\mathrm{NaAsO}_{2}$ ad libitum from gestation days (GD) 8-18 (prenatal only exposure), and the offspring were sacrificed at 10 or 16 weeks. In another group, the arsenic exposure continued throughout gestation (from GD8), birth and postnatally until offspring were sacrificed at 10 or 16 weeks ("whole-life" exposure). Summary of treatment protocols is as follows.

Protocol $A: n=7$; Control, 0 ppm arsenic, 10 or 16 weeks

Protocol B: $n=7-9 ; 4.9 \mathrm{ppm}$ arsenic prenatal only, 10 or 16 weeks

Protocol C: $n=11-13 ; 4.9$ ppm arsenic "whole life", 10 or 16 weeks

Protocol D: $n=7 ; 1 \mathrm{ppm}$ arsenic prenatal only, 16 or 24 weeks

Protocol E: $n=10 ; 1 \mathrm{ppm}$ arsenic "whole life" 16 weeks 
Throughout the course of study all mice were maintained on standard chow (not high in fat), and anesthetized with pentobarbital $(150 \mathrm{mg} / \mathrm{Kg})$ at the end of treatment protocol. Blood and tissues were removed for analysis.

\section{Atherosclerotic lesion analysis}

For morphometric analysis, the entire aorta from the heart extending to $5 \mathrm{~mm}$ after bifurcation of the iliac arteries and including the subclavian right and left common carotid arteries was removed for lesion analysis en face. The aorta was cleaned of peri-adventitial tissue under a dissecting microscope. The aorta was dissected longitudinally to expose the intimal surface. The aortic arch was stained with Sudan IV for the presence of lipids. The aortic arch was defined as the region from ascending arch to $3 \mathrm{~mm}$ distal to subclavian artery (Srivastava et al., 2007). Percent lesion area was calculated using Image $\mathrm{J}$ software (National Institute of Health, USA).

For the analysis of aortic valves, the upper section of the heart tissue was frozen in Tissue Tek OCT (Sakura, CA, USA) reagent and serial cryosections of $8 \mu \mathrm{m}$ thickness were taken from the origin of the aortic valve leaflets throughout the aortic sinus. A total of 37 serial sections from the aortic sinus from each mouse were collected. Sections were stained with oil red $\mathrm{O}$ and counterstained with hematoxylin. Mean lesion area was calculated from the analysis of digital images obtained from 10 serial sections from each mouse using Metamorph imaging software. 


\section{Plasma lipids and cytokine/chemokine analysis}

Blood was withdrawn by cardiac puncture. Disodium EDTA ( $3 \mathrm{mM})$ and sodium citrate were used as anti-coagulants. The blood was centrifuged at $2000 \times g$ for $20 \mathrm{~min}$ at room temperature to obtain plasma. Plasma cholesterol, phospholipids and triglycerides were measured using commercial kits from Wako Chemicals USA (Richmond, VA). For cytokine measurements, plasma was centrifuged at $13,000 \times g$ for 5 min to clear plasma. Plasma cytokine levels (IL-1 $\beta$, IL-6, IL-10, MCP-1, KC, VEGF, and where indicated IFNץ, TNF- $\alpha$, MIP1- $\alpha$ and GM-CSF) were measured using an immunoassay multiplex bead based kit (Millipore Corporation, Billerica, MA) on a Luminex $200^{\mathrm{TM}}$ IS (Luminex Corporation, Austin TX).

\section{Exosome isolation}

Circulating exosomes were isolated from plasma as described (Li et al., 2009) with some slight modifications. Eight hundred $\mu \mathrm{L}$ of RPMI-1640 medium was added to $200 \mu \mathrm{L}$ of plasma, and the sample was centrifuge at $2,000 \times g$ for 10 $\min$ at $4^{\circ} \mathrm{C}$. Supernatant was transferred to $15 \mathrm{~mL}$ tubes, avoiding pellet at the bottom or fat at the top if present. Supernatant was diluted to $10 \mathrm{~mL}$ with cold PBS, centrifuged at $10,000 \times g$ for $20 \mathrm{~min}$ at $4^{\circ} \mathrm{C}$ to remove large debris. Samples were transferred to ultracentrifuge tubes and centrifuged at $100,000 \times g$ for $2 \mathrm{~h}$ using Beckman Ti type 70.1 rotor to pellet exosomes. Exosomes were resuspended in $50 \mu \mathrm{L}$ phosphate buffered saline (PBS) and protein concentration was determined using Bradford assay (Bio-Rad Corp., Hercules, CA). 


\section{Western blot analysis}

Proteins $(10-15 \mu \mathrm{g})$ were separated by SDS-PAGE. Proteins were transferred to nitrocellulose membrane and blots were probed with rabbit monoclonal Hsp70 antibody (1:1000) overnight at $4{ }^{\circ} \mathrm{C}$ (Epitomics Inc., Burlingame, CA), and with corresponding rabbit secondary antibody linked to HRP. The bound antibodies were visualized using ECL plus substrate (GE Healthcare Bio-Sciences Corp., Piscataway, NJ), and visualized directly on a Storm Phosphoimager in blue flourescence mode (Molecular Dynamics, Sunnyvale, CA). Protein bands were quantitated using the Image Quant software.

\section{Statistical analysis}

Data are expressed as mean \pm SEM. Comparisons among groups were performed using one way ANOVA and student's t-test. However, Wilcoxon ranked sum test was used when the distribution was not normal. 


\section{Results}

Average daily arsenic water consumption and effects of arsenic exposure on body weight

During the "whole-life" arsenic exposure studies, the daily arsenic drinking water consumption was measured during a period of one week (mice ranged from 7-10 weeks old), in order to determine the average arsenic intake by mice. The results (Table 5.1) show that mice exposed to $4.9 \mathrm{ppm}$ arsenic in drinking water consumed $30 \mathrm{ng}$ As/day/mouse compared to $5.7 \mathrm{ng}$ As/day/mouse consumed by mice exposed to $1 \mathrm{ppm}$ arsenic. However, breeder mouse with 12 day old pups consumed up to $87 \mathrm{ng} \mathrm{As/day/mouse} \mathrm{at} 4.9 \mathrm{ppm}$ arsenic exposure.

For the most part, except for the $4.9 \mathrm{ppm}$ arsenic exposure prenatal, arsenic exposure did not alter the body weights of mice at the end of the study (Table 5.2). However, prenatal arsenic exposure at $4.9 \mathrm{ppm}$ arsenic significantly decreased the body weight of 10 week old mice compared to the unexposed age-matched controls.

Prenatal arsenic exposure at lower exposures results in increased atherosclerotic lesion formation

Prenatal arsenic exposure at $49 \mathrm{ppm}$ arsenic exposure accelerates atherosclerosis in $\mathrm{ApoE}^{-/-}$mice (Srivastava et al., 2007). However, the doseresponse effect of prenatal arsenic exposure on the development of 
Table 5.1. Average daily arsenic water consumption

\begin{tabular}{|l|l|l|}
\hline Arsenic dose & $\begin{array}{l}\text { Average daily arsenic } \\
\text { water consumption for } \\
\text { post-weaning mouse }(7- \\
10 \text { weeks old })\end{array}$ & $\begin{array}{l}\text { Average daily arsenic } \\
\text { water consumption for } \\
\text { nursing mouse }\end{array}$ \\
\hline $4.9 \mathrm{ppm}$ As & $6.3 \mathrm{~mL}$ water/day/mouse & $17.7 \mathrm{~mL}$ water/day/mouse \\
\hline $1 \mathrm{ppm}$ As & $5.7 \mathrm{~mL}$ water/day/mouse & ND \\
\hline
\end{tabular}

$\mathrm{ApoE}^{-/-}$mice were maintained on tap water (control) or exposed to drinking water containing sodium arsenite (4.9 or $1 \mathrm{ppm}$ arsenic) prenatal or "whole-life" for the indicated period of time. ND is data not measured. 
Table 5.2. Effects of arsenic exposure on body weight

\begin{tabular}{|c|c|c|c|c|}
\hline $\begin{array}{c}\text { Arsenic } \\
\text { dose }\end{array}$ & Age (week) & Unexposed & $\begin{array}{c}\text { Prenatal only } \\
\text { exp. }\end{array}$ & $\begin{array}{c}\text { "Whole-life" } \\
\text { exp. }\end{array}$ \\
\hline $4.9 \mathrm{ppm}$ As & 10 & $28 \pm 1 \mathrm{~g}$ & $24 \pm 1 \mathrm{~g}^{*}$ & $26 \pm 1 \mathrm{~g}$ \\
\cline { 2 - 5 } & 16 & $28 \pm 1 \mathrm{~g}$ & $\mathrm{ND}$ & $28 \pm 1 \mathrm{~g}$ \\
\hline $1 \mathrm{ppm}$ As & 16 & $28 \pm 1 \mathrm{~g}$ & $27 \pm 1 \mathrm{~g}$ & $27 \pm 0.4 \mathrm{~g}$ \\
& 24 & $30 \pm 1 \mathrm{~g}$ & $28 \pm 1 \mathrm{~g}$ & $\mathrm{~N} / \mathrm{A}$ \\
\cline { 2 - 5 } & & & & \\
\hline
\end{tabular}

$\mathrm{ApoE}^{-/-}$mice were maintained on tap water (control) or exposed to drinking water containing sodium arsenite (4.9 or $1 \mathrm{ppm}$ arsenic) prenatal or "whole-life" for the indicated period of time. ND is data not measured. N/A is no mice at this age in exposure group. Values are expressed as mean \pm SEM. ${ }^{*} p<0.05$ compared to control 
atherosclerosis is unknown. Thus, in this study, the effects of lower arsenic prenatal exposures on atherosclerosis were determined. The data (Fig. 5.1) show that atherosclerotic lesion formation in aortic arches appeared increased 2.9 -fold at age 10 weeks $(p<0.12)$ and 1.9 -fold at age 16 weeks $(p<0.27)$ in mice exposed to $4.9 \mathrm{ppm}$ arsenic. With lower exposure of $1 \mathrm{ppm}$ arsenic, lesion area was significantly increased 2.3 -fold $(p<0.05)$ at 16 weeks. Lesions were primarily localized in the area of low shear stress. Interestingly, $1 \mathrm{ppm}$ arsenic prenatal exposure apparently induced more lesion formation than $4.9 \mathrm{ppm}$ arsenic. However, analysis of aortic tree and arch of 24 week old mice showed no difference in lesion formation with $1 \mathrm{ppm}$ arsenic exposure.

\section{"Whole-life" arsenic exposure increases atherosclerotic lesion formation}

Next, I examined how prenatal arsenic exposure may interact with later life exposure in inducing atherosclerosis. For these experiments, arsenic exposure continued throughout gestation (from GD8) and birth, and continued postnatally until offspring were sacrificed (Protocols $\mathrm{C}$ and $\mathrm{E}$ ). Lesion formation in these mice was compared with unexposed mice (Protocol A), or mice exposed to arsenic prenatally only (Protocol B and D). Data are shown in Fig. 5.2. Compared to unexposed mice, "whole-life" exposure to $4.9 \mathrm{ppm}$ arsenic did not affect lesion formation at 10 weeks, but increased lesion formation 2.3 -fold $(p<0.01)$ in aortic arches of 16 week old mice. However, compared to mice exposed to $4.9 \mathrm{ppm}$ arsenic prenatally, "whole-life" arsenic exposure did not enhance lesion formation at 10 or 16 weeks, but rather appeared to decrease prenatal arsenic-induced 

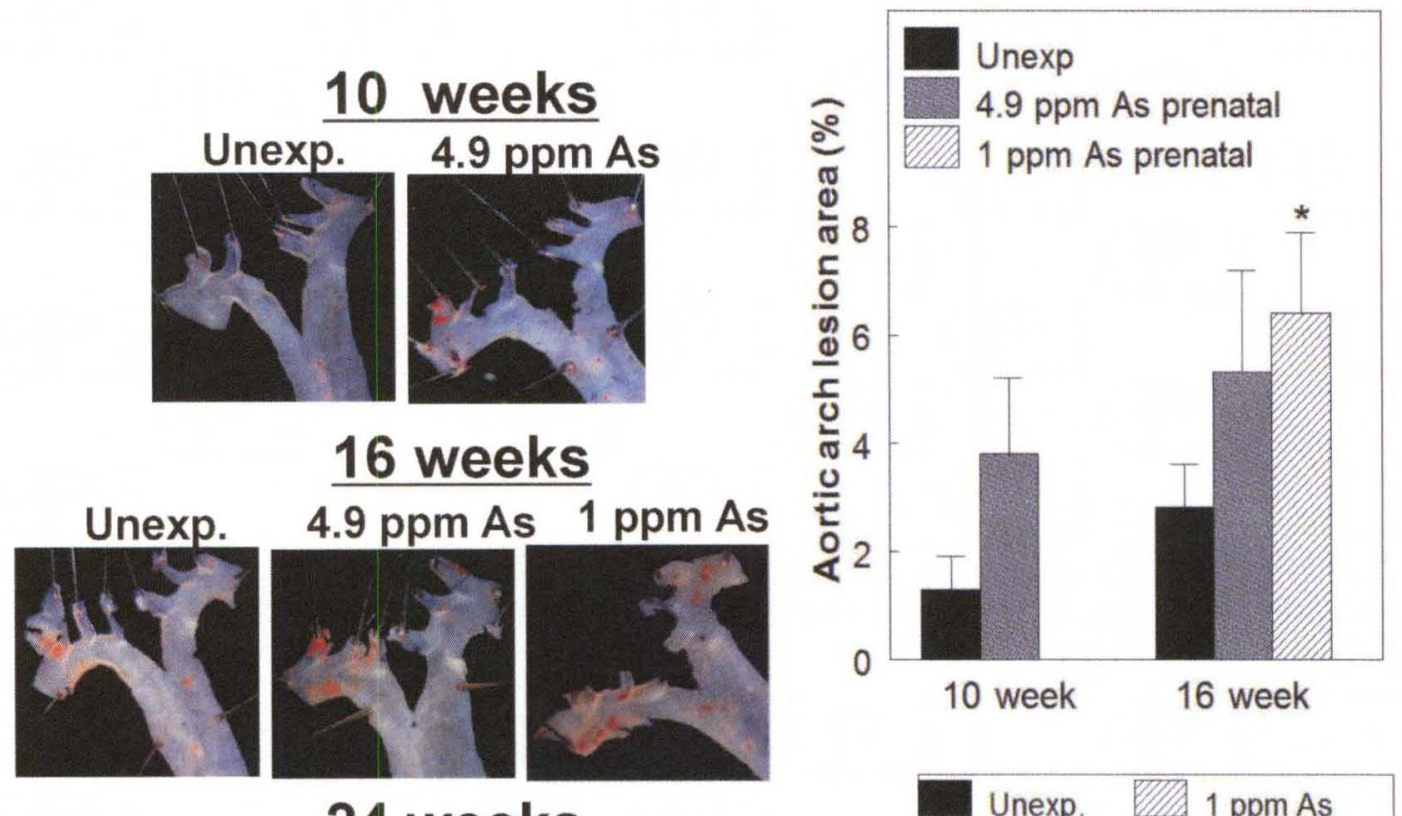

\section{4 weeks}
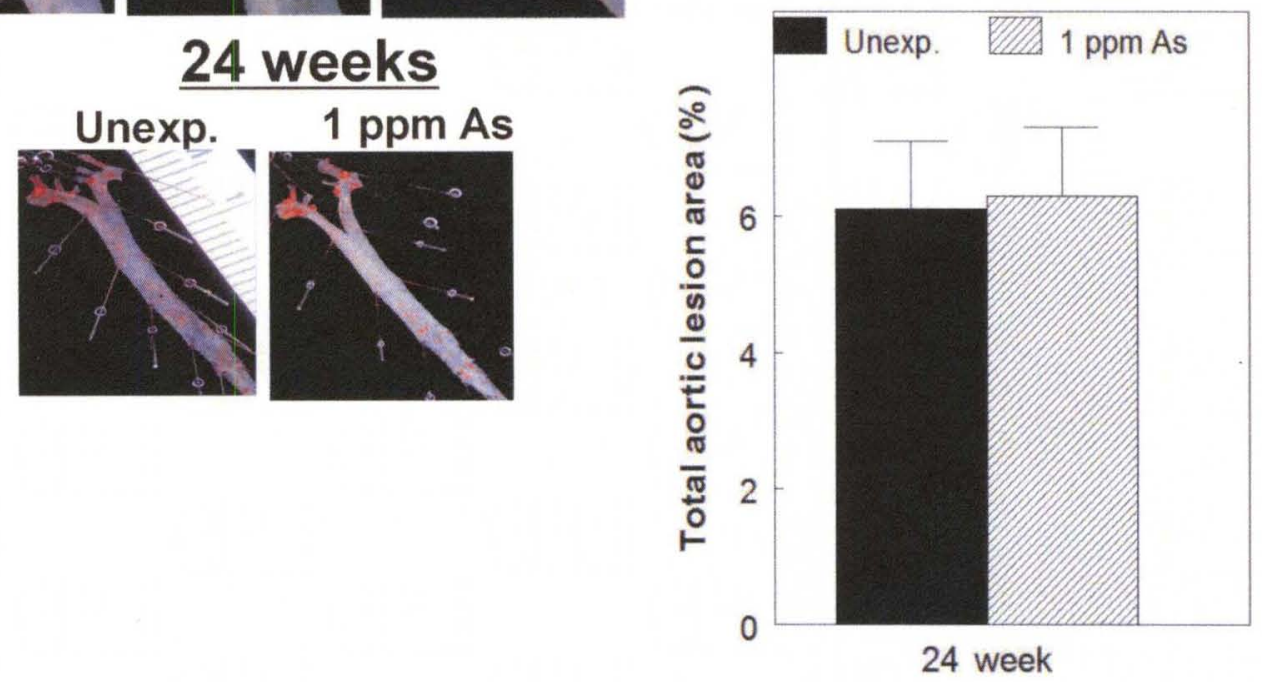

Figure 5.1. Effects of low dose prenatal arsenic exposure on

atherosclerotic lesion formation. Pregnant $\mathrm{ApoE}^{-1-}$ mice were maintained on tap water (Protocol A) or water containing arsenic at a dose of $4.9 \mathrm{ppm}$ As (Protocol B) or $1 \mathrm{ppm}$ As (Protocol D) from GD8-GD18. Offspring were sacrificed at 10,16 or 24 week of age and lesion formation was examined in the aortic arch or aortic tree where indicated. Data are mean \pm SEM. ${ }^{*}=p<0.05$ compared to unexposed mice 
lesion formation at 10 weeks. Similarly to prenatal arsenic exposure, "whole-life" arsenic exposure at $1 \mathrm{ppm}$ arsenic increased lesion formation 2.6 -fold in the aortic arches $(p<0.02)$ compared to unexposed 16 week old mice. However, "whole-life" arsenic exposure did not enhance prenatal arsenic-induced atherosclerosis. It should be noted that similarly to prenatal arsenic exposures, 1 ppm arsenic "whole-life" exposure appeared to induce more lesion formation than the higher $4.9 \mathrm{ppm}$ arsenic exposure.

\section{Effects of arsenic exposure on plasma lipids}

Next, I examined whether lower arsenic exposure affects plasma lipids.

Compared to unexposed mice, mice exposed to $4.9 \mathrm{ppm}$ arsenic prenatally only had lower plasma triglycerides $(27 \%$ decrease, $p<0.05)$ at 10 weeks, but had higher plasma cholesterol ( $26 \%$ increase, $p<0.05$ ) at 16 week (Fig. $5.3 \mathrm{~A})$. On the other hand, mice with $4.9 \mathrm{ppm}$ arsenic "whole-life" exposure had $27 \%$ lower plasma cholesterol $(p<0.001)$ compared to unexposed mice, and $31 \%$ lower plasma cholesterol $(p<0.001)$ compared to prenatal arsenic-exposed mice at 10 weeks. Similarly, compared to prenatal arsenic-exposed 16 week old mice, mice with 4.9 ppm arsenic "whole-life" exposure had $25 \%$ lower plasma cholesterol $(p<0.008)$. At 16 weeks of age, mice with lower arsenic exposure of $1 \mathrm{ppm}$ arsenic prenatal only had $42 \%$ lower plasma triglycerides $(p<0.05)$ compared to

unexposed mice (Fig. 5.3 B), while mice with 1 ppm arsenic "whole-life" exposure had $38 \%$ higher plasma cholesterol compared to prenatal exposure $(p<0.0002)$. 

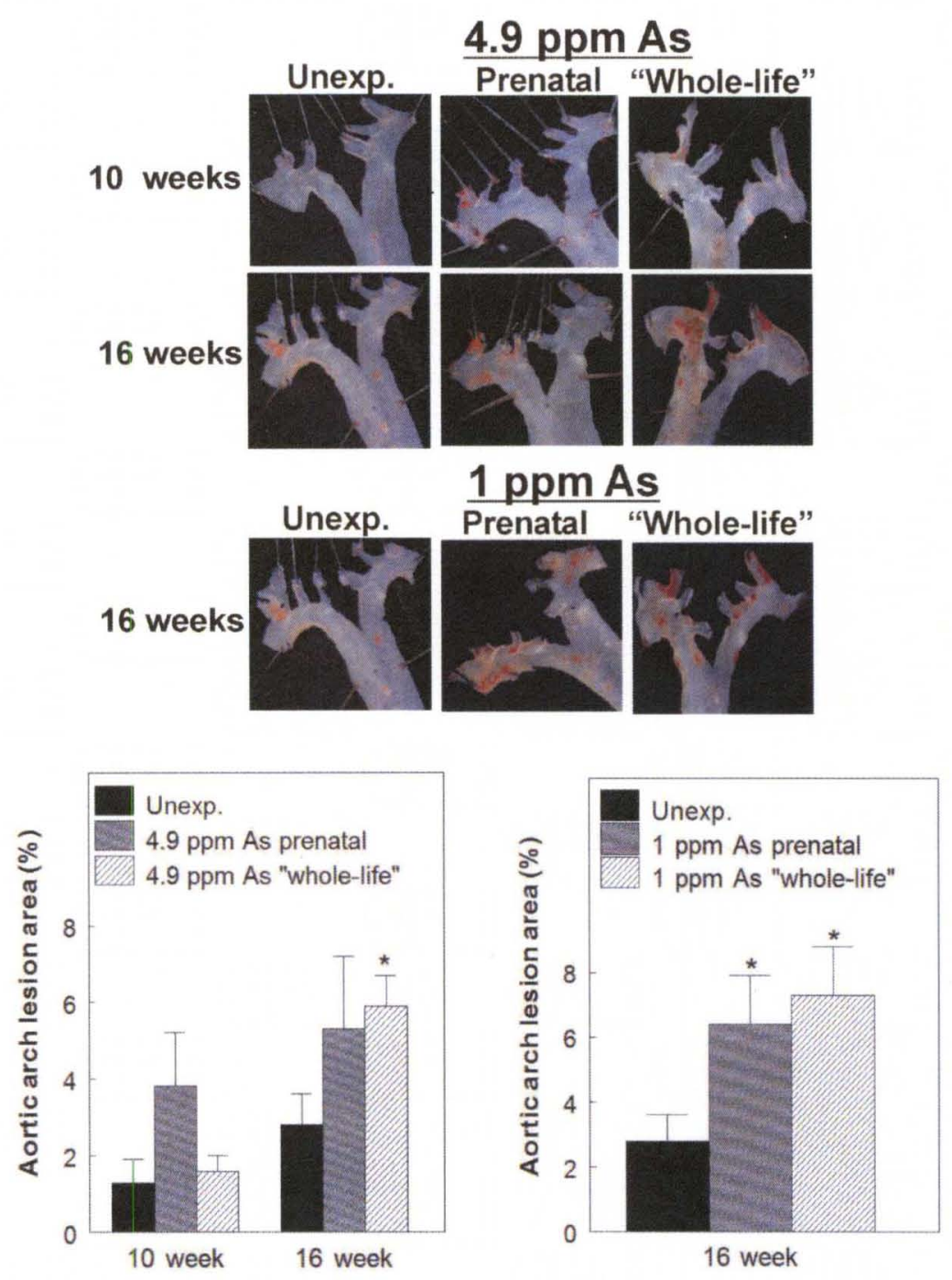

Figure 5.2. Effects of "whole-life" arsenic exposure on atherosclerotic lesion formation. Pregnant $A p o E^{-l-}$ mice were maintained on tap water (Protocol A) or water containing arsenic at a dose of $4.9 \mathrm{ppm} \mathrm{As} \mathrm{(Protocol} \mathrm{C)} \mathrm{or} 1$ ppm As (Protocol E) continuously from GD8 to birth, and pups were exposed postnatally until day of sacrifice at 10 or 16 weeks of age. Lesion formation was examined in the aortic arch. Data are mean \pm SEM. ${ }^{*}=p<0.05$ compared to unexposed mice. 


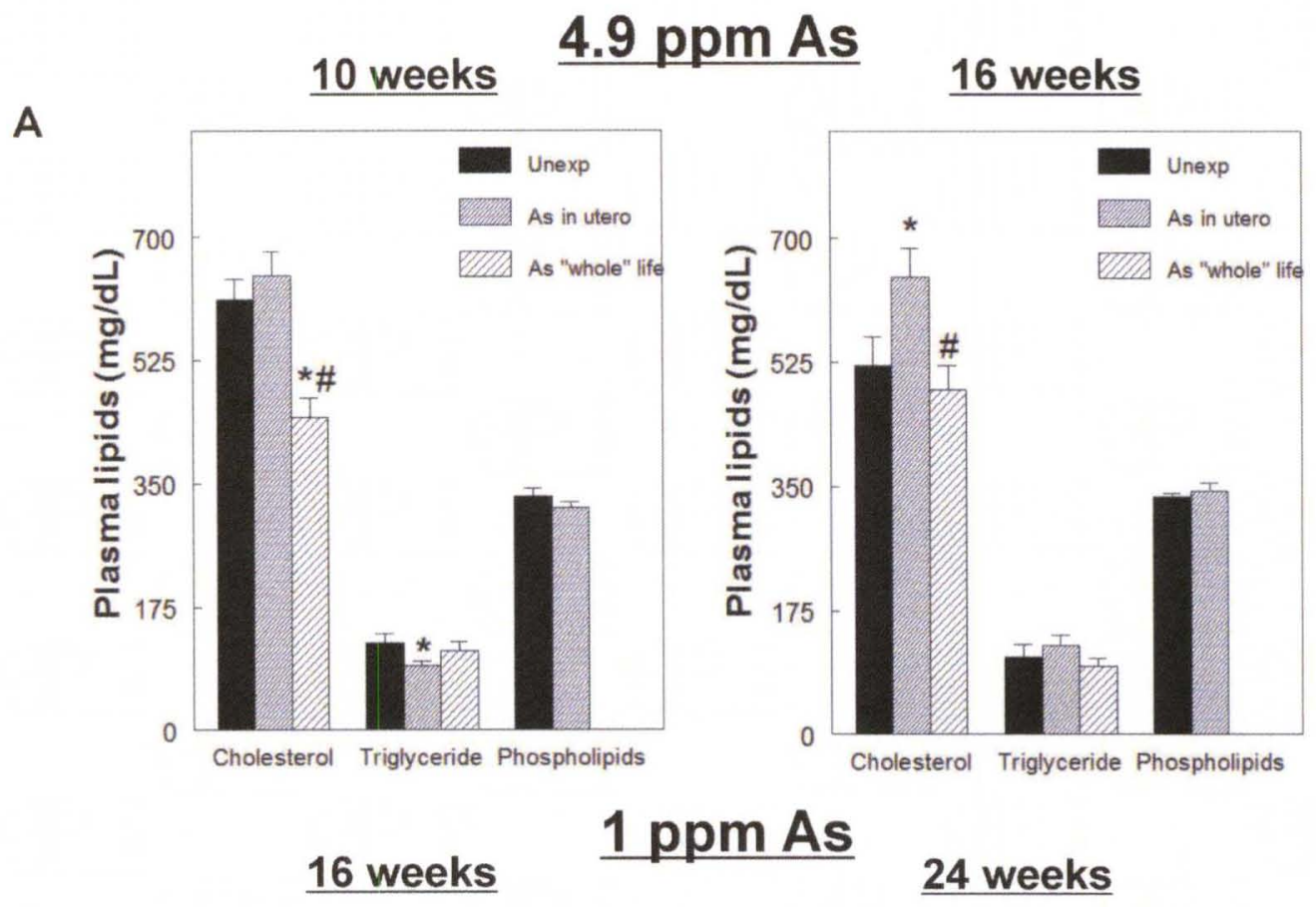

B
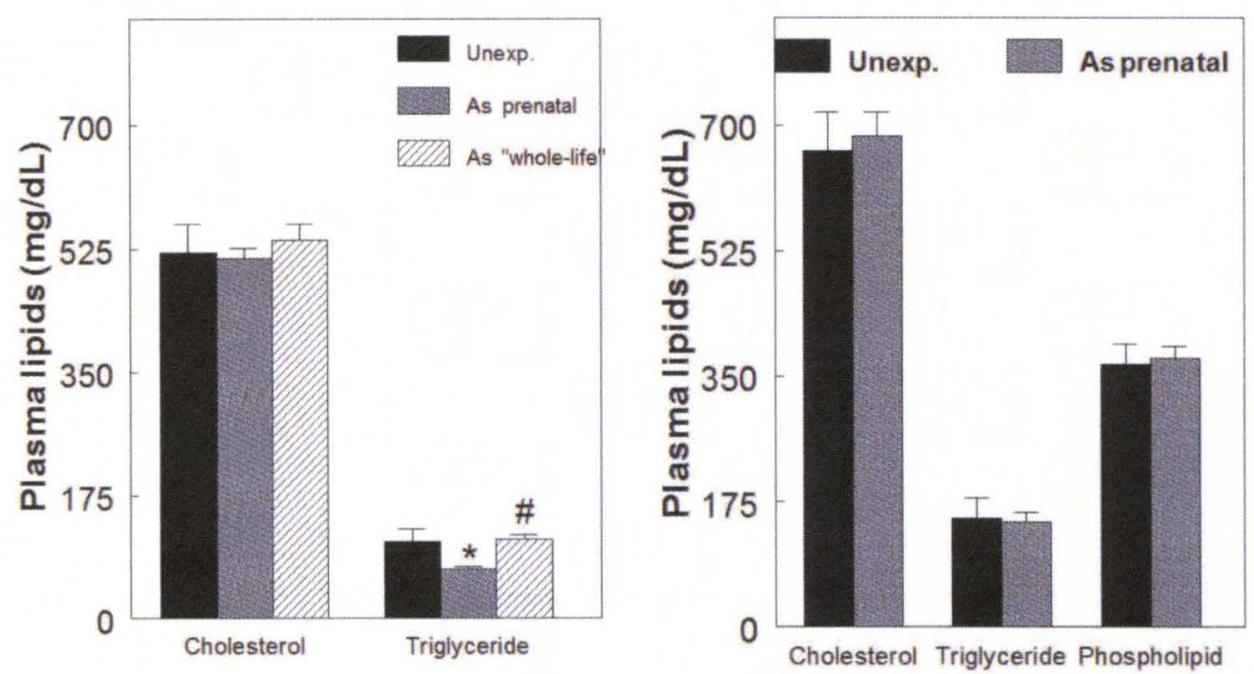

Figure 5.3. Effects of arsenic exposure on plasma lipids. ApoE ${ }^{-/}$mice were exposed to arsenic prenatal or "whole-life" at a dose of $4.9 \mathrm{ppm}$ As or $1 \mathrm{ppm}$ arsenic as described in Methods. Mice were sacrificed at 10, 16 or 24 weeks of age, and plasmas were analyzed for lipid concentrations. Data are mean \pm SEM. ${ }^{*} p=<0.05$ compared to unexposed mice, and $\# p<0.05$ compared to prenatal arsenic-exposed mice. 
Effects of arsenic exposure on plasma cytokine/chemokine expression

Pro-inflammatory cytokines and chemokines play a role in atherogenesis.

Therefore, I determined the effect of arsenic exposure on the expression of plasma cytokines and chemokines. Mice with prenatal arsenic exposure at high exposure of $49 \mathrm{ppm}$ arsenic showed increased plasma expression of $\mathrm{KC}$ $(p<0.02)$ and VEGF $(p<0.02)$ at 3 week; and IL-6 $(p<0.05)$ and KC $(p<0.05)$ at 10 weeks compared to unexposed controls (Fig. 5.4 A). However, mice with lower exposures of 4.9 and $1 \mathrm{ppm}$ arsenic prenatal only did not show altered expression of any of the plasma cytokines/chemokines measured (Fig. 5.4 B). On the other hand, mice with $4.9 \mathrm{ppm}$ arsenic "whole-life" exposure had increased plasma IL-1 $\beta p<0.05), K C(p<0.04)$ and MCP-1 $(p<0.03)$ at 10 weeks while only IL-6 $(p<0.04)$ was increased at 16 weeks compared to unexposed mice (Fig. 5.5 A). Mice exposed "whole-life" to much lower arsenic exposure of $1 \mathrm{ppm}$ arsenic did not show altered expression of plasma cytokines/chemokines at age 16 weeks (Fig. $5.5 \mathrm{~B}$ ). 


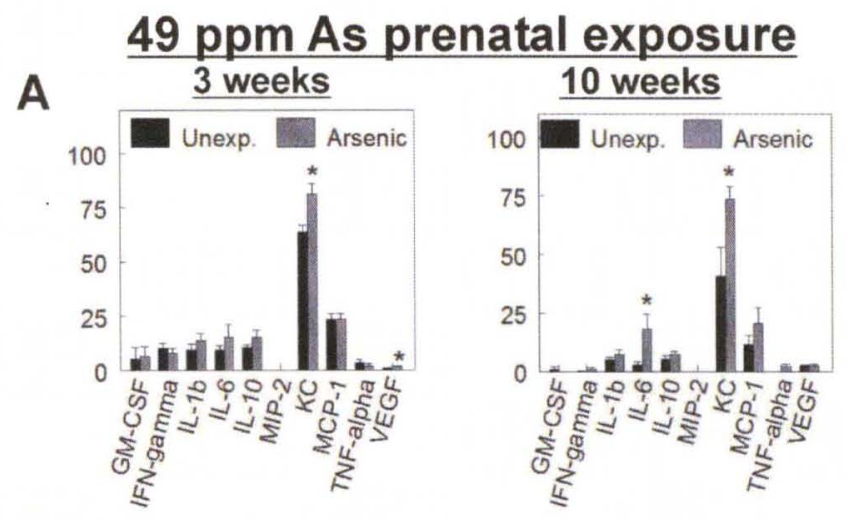

\section{$4.9 \mathrm{ppm}$ As prenatal exposure}

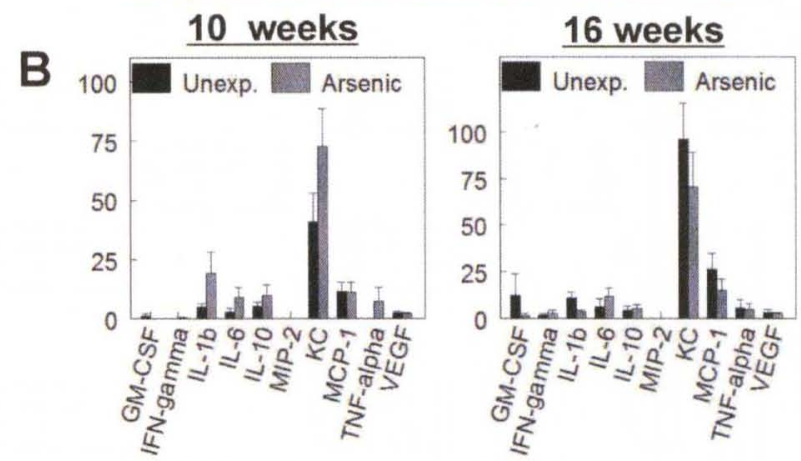

\section{1 ppm As prenatal exposure}

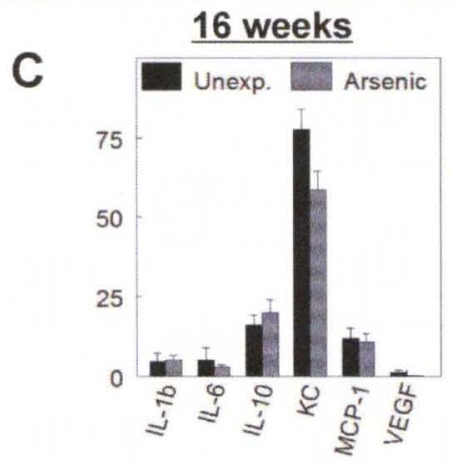

Figure 5.4. Effects of prenatal arsenic exposure on plasma cytokine/chemokine expression. Plasmas from mice exposed to $49,4.9$ or 1 ppm arsenic prenatal were analyzed for cytokine/chemokine expression using an immunoassay multiplex bead based kit (Millipore Corporation, Billerica, MA) on a Luminex $200^{\mathrm{TM}}$ IS (Luminex Corporation, Austin TX). Data are mean \pm SEM. ${ }^{*}=p<0.05$ compared to unexposed mice 

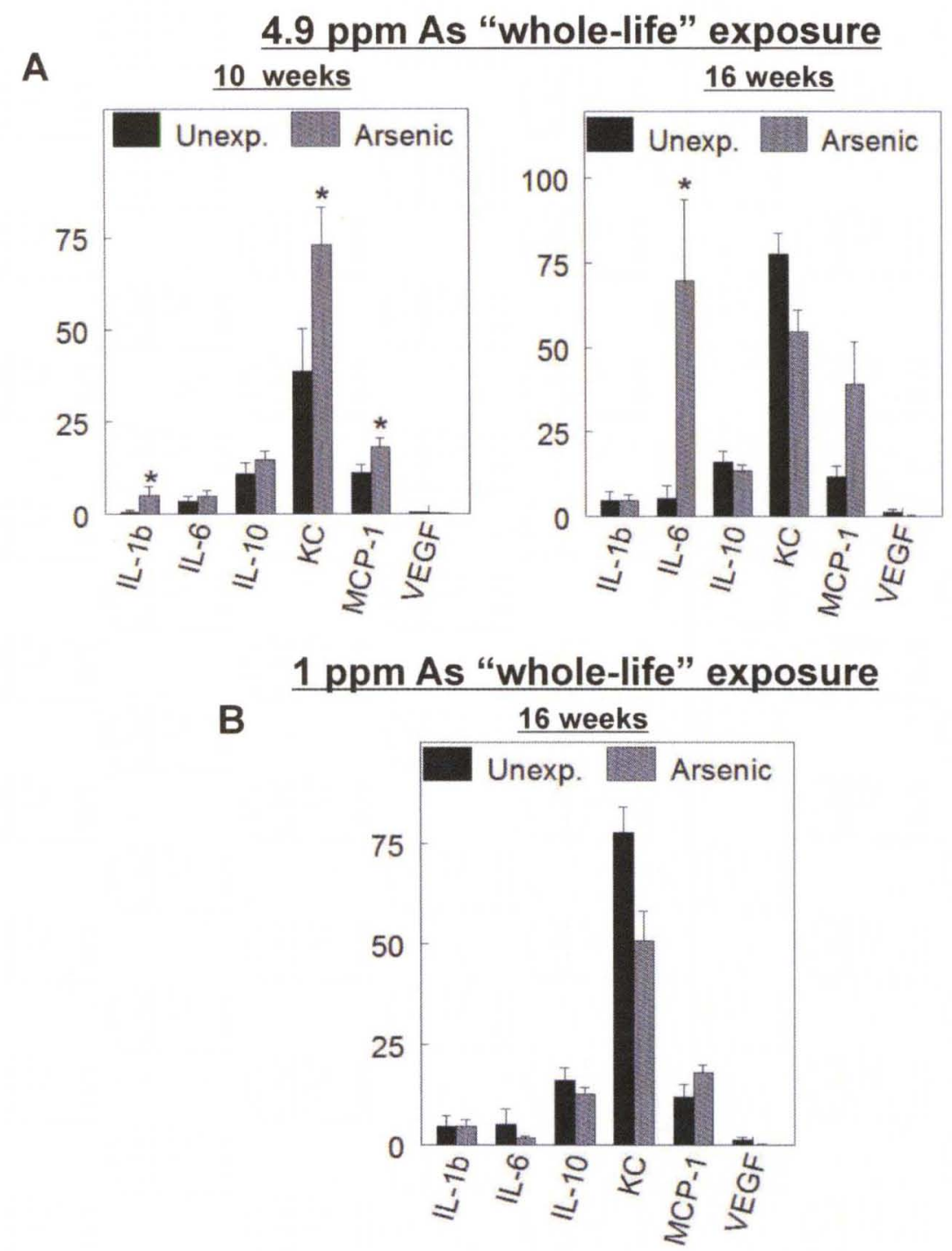

Figure 5.5. Effects of "whole-life" arsenic exposure on plasma cytokine/chemokine expression. Plasmas from mice with "whole-life" arsenic exposure at 4.9 or $1 \mathrm{ppm}$ arsenic exposure were analyzed for cytokine/chemokine levels using an immunoassay multiplex bead based kit (Millipore Corporation, Billerica, MA) on a Luminex $200^{\mathrm{TM}}$ IS (Luminex Corporation, Austin TX). Data are mean \pm SEM. ${ }^{*} p<0.05$ compared to unexposed mice 


\section{Discussion}

Accumulating evidence from epidemiological studies shows that arsenic exposure causes CVD and mortality (States et al., 2009b). These epidemiological studies have been confirmed in animal models, with both prenatal (Srivastava et al., 2007) and postnatal (Lemaire et al., 2011; Srivastava et al., 2009) arsenic exposures reported to increase atherosclerosis which underlies most CVD. In addition, CVD showed arsenic dose-response in humans (Chen et al., 1996; Chen et al., 2011). Similarly, in animal models, postnatal arsenic exposure at 49, 4.9 and $1 \mathrm{ppm}$ arsenic exposure produced a dose-dependent increase in atherosclerotic lesion formation in $\mathrm{ApoE}^{-1 /}$ mice, with disease incidence increasing with higher arsenic exposures (Srivastava et al., 2009). However, a more recent study showed an inverse dose-response effect of arsenic-induced atherosclerosis. In this study (Lemaire et al., 2011, mice postnatally exposed to much lower arsenic exposure ( $0.2 \mathrm{ppm}$ arsenic) had more atherosclerotic lesion formation than mice with moderate exposures (1 ppm arsenic).

Whereas there is significant knowledge on the dose-response effect of postnatal arsenic exposures on the induction of atherosclerosis, little is known how lower doses of prenatal arsenic exposure may modulate atherogenesis. Thus, in this study, the effects of lower arsenic prenatal exposures on atherosclerosis were determined. This study for the first time has shown that prenatal arsenic exposure appears to induce more atherosclerosis at lower exposures than at higher exposures. The increase in lesion formation in the aortic arch appeared 
greater in mice with $1 \mathrm{ppm}$ arsenic prenatal exposure than those with $4.9 \mathrm{ppm}$ arsenic exposure. These data are consistent with the postnatal arsenic study reported by (Lemaire et al., 2011), but are different with the (Srivastava et al., 2009) study. This difference may be attributed to the difference in life stage exposures, prenatal versus postnatal exposures.

Whereas circulating cholesterol and triglycerides are risk factors for developing atherosclerosis, ischemic heart disease in humans associated with arsenic exposure was reported to be independent of alterations in serum lipids (Hsueh et al., 1998). Similarly, in animal models, both prenatal and postnatal arsenicinduced atherosclerosis is not associated with altered plasma cholesterol. However, triglyceride levels have been reported to be altered by arsenic exposures associated with increased atherosclerosis. Both prenatal (Srivastava et al., 2007) and postnatal (Srivastava et al., 2009) arsenic-induced atherosclerosis were associated with significant decrease in plasma triglyceride. However, another study (Lemaire et al., 2011) reported an increase in plasma triglycerides associated with arsenic-induced atherosclerosis. In the current study, lower arsenic exposure prenatal significantly decreased plasma triglycerides at 10 weeks ( $4.9 \mathrm{ppm}$ arsenic) and 16 weeks (1 ppm arsenic) which is consistent with earlier report with 49 ppm arsenic exposure (Srivastava et al., 2007). These data suggest that despite a significant decrease in plasma triglycerides, prenatal arsenic exposure at lower doses increases lesion formation. Whereas plasma triglycerides were not altered with $4.9 \mathrm{ppm}$ arsenic exposures prenatal when mice were 16 weeks of age, plasma cholesterol was 
significantly increased. This increased plasma cholesterol was surprising because it is the first reported observation with arsenic-induced atherosclerosis. The increase in plasma cholesterol caused by arsenic exposure might be contributing to the accelerated atherogenesis.

Collectively, these experimental data along with human data reporting the occurrence of myocardial infarction in infants exposed to arsenic (Rosenberg, 1973; Rosenberg, 1974), suggest that infants might be at high risk to the atherogenic effects of arsenic even at lower exposures.

Prenatal exposure to arsenic induces atherosclerosis later in life. However, it is clear that human environmental exposure to inorganic arsenic occurs during the entire life span, and not limited to the prenatal period. How prenatal arsenic exposure may modulate exposure that occurs after gestation and during entire life span ("whole-life") has been unclear. According to the predictive adaptive response (Gluckman and Hanson, 2004), prenatal arsenic exposure will protect against later life exposure due to adaptations made by the fetus in preparation for postnatal life. For example, gestational high-fat diet results in endothelial dysfunction and hypertension in adult rat offspring (Khan et al., 2004; Khan et al., 2003). However, if the offspring are also maintained on high-fat diet after birth, endothelial dysfunction although not the hypertension is prevented (Khan et al., 2004). Conversely, in transplacental arsenic-induced carcinogenesis mouse model, "whole-life" arsenic exposure resulted in higher tumor incidence than prenatal only exposures (Tokar et al., 2011), thus suggesting that late life exposure enhanced prenatal arsenic exposure. In the current study, similar to 
prenatal exposures, atherosclerosis appears to be increasing with decreasing doses of "whole-life" arsenic exposures. However, when compared to prenatal only exposure, "whole-life" arsenic exposure at any dose did not alter prenatal arsenic-induced atherosclerosis. In addition, "whole-life" arsenic exposure did not alter plasma triglycerides when compared to unexposed groups, but decreased plasma cholesterol (at $4.9 \mathrm{ppm}$ arsenic, 10 weeks) similar to prenatal exposure. However, "whole-life" arsenic exposure altered some of the plasma effects induced by prenatal exposure. For example, "whole-life" arsenic exposure attenuated prenatal arsenic-induced plasma cholesterol (4.9 ppm arsenic, 16 week), and elevated prenatal arsenic-decreased triglyceride (1 ppm arsenic, 16 week) to control levels. These plasma lipid data suggest that "whole-life" arsenic exposures may mediate atherogenesis through mechanisms which might be different from prenatal exposure. Together, these compelling data suggest that once atherogenesis is initiated by arsenic exposure prenatal, the disease outcome is independent on further exposures occurring later in life. Thus, there is an apparent need to protect pregnant mothers from arsenic exposures even in populations with very low exposure levels such as the United States in order to prevent elevated CVD.

Inflammation plays a key role in atherogenesis. Atherogenesis requires local chemokine production for the migration of leukocytes. Furthermore, vascular cells (endothelial cells, monocytes/macrophages, and smooth muscle cells) involved in atherogenesis secrete chemokines and pro-inflammatory cytokines. The chemokine IL-8 (human ortholog of mouse $\mathrm{KC}$ ) is an angiogenic factor (Koch 
et al., 1992), and a chemotactic factor for vascular smooth muscle cells (Yue et al., 1993), T-cells (Lloyd et al., 1996), and monocytes (Gerszten et al., 1999). Arsenic is reported to induce the expression of IL-8 in human aortic endothelial cells (Simeonova et al., 2003). IL-6 is a pro-inflammatory cytokine and is recognized as a marker for vascular inflammation (Kleemann et al., 2008). In addition, circulating IL-6 is an independent risk factor coronary artery disease (Luc et al., 2003), and increased IL-6 expression in plaques strongly correlates with plaque instability and rupture (Biasucci et al., 1996). MCP-1 is important in the trafficking of macrophages. Genetic deletion of MCP-1 and IL-6 in mice decreased atherosclerotic lesion formation (Gu et al., 1998; Schieffer et al., 2004). IL-1 $\beta$ has pro-atherogenic properties associated with upregulation of endothelial adhesion molecules, and activation of macrophages and vascular cells (Ait-Oufella et al., 2011). VEGF is an angiogenic factor, can function as an inflammatory cytokine, promoting lesion formation and plaque instability (Holm et al., 2009). Therefore, I determined the effects of prenatal and "whole-life" arsenic exposures on plasma cytokine/chemokine expression. I observed that both exposure types increased specific plasma cytokines/chemokines which include $\mathrm{KC}$ (murine ortholog of IL-8), IL-6, IL-1 $\beta, \mathrm{MCP}-1$ and VEGF. The cytokine/chemokine expression was age-, dose-, and exposure type-specific. In addition, whereas prenatal arsenic exposure alone altered cytokine expression only at high exposure (49 ppm arsenic), "whole-life" exposure altered cytokine expression at lower exposure levels (4.9 ppm arsenic). These data are consistent with epidemiologic data (Wu et al., 2003) showing increased plasma IL-6 
concentrations in arsenic exposed humans, and with animal studies (Srivastava et al., 2009) showing arsenic-induced vascular and circulating concentrations of MCP-1 and IL-6. Furthermore, prenatal arsenic exposure is reported to alter the gene expression profile (including IL-8 and IL-1 $\beta$ ) in newborn cord blood (Fry et al., 2007). Collectively, my experimental data along with reported data suggest that arsenic-induced inflammation plays an important role in accelerating atherogenesis.

In summary, this study indicates that the induction of atherosclerosis appears to be increasing with decreasing arsenic levels of prenatal exposures. Atherosclerosis induction by arsenic exposure is associated with alterations in plasma cholesterol and triglycerides. Furthermore, "whole-life" exposures also result in increased lesion formation similar to prenatal exposure when compared with controls. Interestingly, atherosclerotic lesion area was the same in both prenatal only and "whole-life" arsenic exposures, suggesting only the prenatal exposure counts. However, there appear to be an interaction- but not an additive effect between prenatal only and later life exposures. Circulating cytokine/chemokine expression showed dose-specific increase, thus indicating inflammation. Our observations suggest that disease may be even higher at lower exposures. Therefore, it will be important to examine the effect of prenatal arsenic exposure at much lower doses (doses $<1 \mathrm{ppm}$ arsenic). Future studies will determine lesion formation in aortic valves and also determine exosomal Hsp70 expression. 


\section{CHAPTER VI}

\section{General conclusions and future studies}

Inorganic arsenic has been considered a hazardous compound for many years because of its deleterious effects on human health worldwide. The most established toxic effect of arsenic on human health is cancer, with arsenic reported to cause lung, liver, skin, and bladder cancer. However, it is also now accepted that arsenic exposure, both prenatally and postnatally also causes atherosclerosis which underlies most CVD in humans and in animal models. Despite the strong evidence implicating arsenic exposure in the development of CVD, it is still unclear how arsenic mediates disease progression. The first part of this study focused more on the liver as the source of atherogenic stimulus, based on several reports of how the risk of CVD increases with liver disease. A major finding in this dissertation is that prenatal arsenic exposure causes liver damage several weeks later during postnatal life in $\mathrm{ApoE}^{-/-}$mice. This liver damage was characterized by increased plasma ALT and AST liver enzymes, and IL-6 expression, with no major changes in liver histology and hepatic inflammation. These findings are similar to earlier reports showing induction of liver damage by chronic postnatal arsenic exposures in humans (Mazumder, 2005) and animal models (Arteel et al., 2008; Waalkes et al., 2003; Santra et al., 2000; Wu et al., 2008). However, what is different and new about the current study is that 
whereas liver damage was induced by chronic postnatal arsenic exposures for several months in earlier studies, liver damage was induced by a relatively shorter 10 day prenatal exposure in the current study. The liver damage was manifested several weeks ( 10 and 24 weeks) after arsenic exposure is removed. In addition, this is the first study showing the induction of liver damage by arsenic exposure in an atherosclerosis animal model as opposed to reported studies performed in other mice strains such as $\mathrm{C} 57 \mathrm{BI} / 6 \mathrm{~J}, \mathrm{C} 3 \mathrm{H}$ and $\mathrm{BALB} / \mathrm{c}$. The induction of liver damage by prenatal arsenic exposure in the $\mathrm{ApoE}^{-1}$ mice is a significant finding because these findings confirm earlier epidemiological reports (Brea et al., 2005; Targher et al., 2004; Targher et al., 2006) showing that the risk of developing atherosclerosis increases with liver disease. In addition, elevated plasma ALT and AST are independent risk factors for atherosclerosis, independent of traditional risk factors such as metabolic syndrome (Adibi et al., 2007; Bellentani et al., 2008; Schindhelm et al., 2007). However, this study shows that prenatal arsenic exposure does not sensitize the liver to enhanced liver toxicity owing to LPS, which is different from earlier reports of increased sensitivity to liver damage owing to LPS by chronic postnatal arsenic exposures (Arteel et al., 2008). The lack of sensitivity to liver damage by prenatal arsenic exposure can be attributed to the difference in life-stage exposure, prenatal versus chronic postnatal exposures. These differences suggest that additional postnatal arsenic exposures will be needed to sensitize the liver to enhanced liver damage caused by LPS. A weakness in the LPS study is that only the $24 \mathrm{~h}$ time-point was analyzed after the LPS challenge, considering that the induction 
of cytokines (hepatic or plasma) is temporal. In the future, mice should be euthanized at different time points (e.g. 0,6 12 and $24 \mathrm{~h}$ ) post LPS injection in order to avoid missing the peak levels of cytokine expression as was probably the case with the current study.

Another major finding in this dissertation is the delayed temporal induction of Hsp70 in the livers (3-10 weeks) of mice exposed to arsenic prenatally, thus indicating stress. This finding is similar to earlier reports showing increased Hsp70 expression in animal tissues following arsenic exposures (Andrew et al., 2007; Han et al., 2005; Liu et al., 2001). However, what is different and new and thus a strength in the current study is that whereas the expression of Hsp70 was determined only at one time point or age immediately following arsenic exposure in the earlier studies, the current study investigated Hsp70 expression during prenatal and postnatal development following prenatal arsenic exposure. An absence in the induction of Hsp70 expression immediately following arsenic exposure (at GD18) in the current study indicates Hsp70 expression is not sufficient to be used as a biomarker of arsenic exposure as proposed by earlier studies (Del Razo et al., 2001; Han et al., 2005). In addition, Hsp70 induction observed at 3-10 weeks of age indicates a critical window of enhanced sensitivity to other environmental factors. For example, if the mice are challenged with LPS during this window, they might show increased sensitivity to liver damage. The Hsp70 induction by prenatal arsenic exposure was associated with increased Hsp70 DNA methylation in the body of the gene (indicating an epigenetic effect), and underlying mechanism of induction is likely by increased mRNA stability as 
indicated by decreased miRNA expression. However, future studies are needed to confirm the regulation of $H s p 70$ by the decreased miRNAs. This finding also suggests that the stressed liver cells can release excess Hsp70 in to circulation which can activate macrophages and thus promote atherogenesis as have been earlier reported (Lu and Kakkar, 2010). However, a weakness in the Hsp70 expression study is the lack of evidence of increased plasma exosomal Hsp70 expression associated with the accelerated atherosclerosis. Therefore, future studies are required to determine exosomal Hsp70 expression.

Taken as a whole, these data therefore indicate that the deleterious effects of prenatal arsenic exposure on the liver can be contributing to the increased atherosclerosis observed in the $\mathrm{ApoE}^{-/-}$mouse model.

The second part of this dissertation determined the effects of prenatal arsenic exposure on atherosclerosis and how later life arsenic exposure modifies exposures prenatally. A major finding in this study is that atherosclerotic lesion formation appears to be increasing with decreasing doses of prenatal arsenic exposure. This finding is different from earlier reports of decreasing lesion formation with decreasing doses of postnatal arsenic exposures (Srivastava et al., 2009). The difference in dose-response lesion formation between postnatal and prenatal arsenic exposures might be attributed to the difference in life-stage of exposure. The prenatal exposure interacts with postnatal exposure to change the response. These data indicate that differences exist between prenatal arsenic exposure and postnatal exposures in the induction of atherosclerosis.

Furthermore, "whole-life" arsenic exposure did not enhance lesion formation 
induced by prenatal exposures. Absence of lesion enhancement by later life exposure is a significant finding and a strength in this study, and suggests that only the prenatal exposure counts. In the future, the aortic valves will also be analyzed for lesion formation, to correlate with lesion formation in the aortas. Both exposure types increased plasma cytokines and chemokines related to CVD, indicating inflammation, which is a risk factor contributing to atherosclerosis. These data are quite compelling and indicate that gestation is indeed a very sensitive period of development and toxic exposures to the intrauterine environment can result in deleterious effects that lead to diseases later in life. These data indicate that exposure to arsenic prenatally initiates atherogenesis, which manifest later in life whether or not there is additional latelife exposure. A weakness in this part of the study is that only 2 arsenic doses (4.9 and $1 \mathrm{ppm}$ arsenic) were determined, and thus not enough to conclude on the dose-response curve. In addition, the current study did not include postnatal only exposures to make direct comparisons with prenatal and "whole-life" exposures. Further studies are required to determine the arsenic effects at lower exposures ( $<1 \mathrm{ppm}$ arsenic), and also to determine if there is indeed a threshold exposure level. Indeed, postnatal arsenic exposure was reported to induce more atherosclerotic lesion formation at $0.2 \mathrm{ppm}$ arsenic than at $1 \mathrm{ppm}$ arsenic (Lemaire et al., 2011). This report suggests that prenatal arsenic exposure at exposures $<1 \mathrm{ppm}$ arsenic is likely to induce more atherosclerotic lesion formation. Further studies are also needed to determine if the prenatal arsenic 
effects on atherosclerosis can be reversed by supplementing prenatal arsenicexposed mice with anti-inflammatory therapies during their postnatal life.

In conclusion, mechanisms of prenatal arsenic exposure-induced atherosclerosis include subtle but significant hepatic stress and damage, and increased systemic inflammation. 


\section{REFERENCES}

Adibi P, Sadeghi M, Mahsa M, Rozati G and Mohseni M (2007) Prediction of Coronary Atherosclerotic Disease With Liver Transaminase Level. Liver Int 27:895-900.

Adiels M, Taskinen M R, Packard C, Caslake M J, Soro-Paavonen A, Westerbacka J, Vehkavaara S, Hakkinen A, Olofsson S O, Yki-Jarvinen H and Boren J (2006) Overproduction of Large VLDL Particles Is Driven by Increased Liver Fat Content in Man. Diabetologia 49:755-765.

Ahmed MF, Ahuja S, Alauddin M, Hug S J, Lloyd J R, Pfaff A, Pichler T, Saltikov $C$, Stute $M$ and van G A (2006) Epidemiology. Ensuring Safe Drinking Water in Bangladesh. Science 314:1687-1688.

Ahmed S, Mahabbat-e Khoda, Rekha R S, Gardner R M, Ameer S S, Moore S, Ekstrom E C, Vahter M and Raqib R (2011) Arsenic-Associated Oxidative Stress, Inflammation, and Immune Disruption in Human Placenta and Cord Blood.

Environ Health Perspect 119:258-264.

Ait-Oufella H, Taleb S, Mallat $Z$ and Tedgui A (2011) Recent Advances on the Role of Cytokines in Atherosclerosis. Arterioscler Thromb Vasc Biol 31:969-979.

Andrew AS, Bernardo V, Warnke L A, Davey J C, Hampton T, Mason R A, Thorpe J E, Ihnat M A and Hamilton J W (2007) Exposure to Arsenic at Levels Found InU.S. Drinking Water Modifies Expression in the Mouse Lung. Toxicol Sci 100:75-87.

Arteel GE, Guo L, Schlierf T, Beier J I, Kaiser J P, Chen T S, Liu M, Conklin D J, Miller H L, von M C and States J C (2008) Subhepatotoxic Exposure to Arsenic Enhances Lipopolysaccharide-Induced Liver Injury in Mice. Toxicol Appl Pharmacol 226:128-139.

Asea A (2007) Mechanisms of HSP72 Release. J Biosci 32:579-584

Barker DJ (2007) The Origins of the Developmental Origins Theory. J Intern Med 261:412-417.

Bartel DP (2009) MicroRNAs: Target Recognition and Regulatory Functions. Cell 136:215-233 
Bellentani S, Bedogni G and Tiribelli C (2008) Liver and Heart: A New Link? J Hepatol 49:299-303.

Biasucci LM, Vitelli A, Liuzzo G, Altamura S, Caligiuri G, Monaco C, Rebuzzi A G. Ciliberto $G$ and Maseri A (1996) Elevated Levels of Interleukin-6 in Unstable Angina. Circulation 94:874-877.

Bielecka-Dabrowa A, Barylski M, Mikhailidis D P, Rysz J and Banach M (2009) HSP 70 and Atherosclerosis--Protector or Activator? Expert Opin Ther Targets 13:307-317.

Bouwens L, De B P, Vanderkerken K, Geerts B and Wisse E (1992) Liver Cell Heterogeneity: Functions of Non-Parenchymal Cells. Enzyme 46:155-168.

Brea A, Mosquera D, Martin E, Arizti A, Cordero J L and Ros E (2005) Nonalcoholic Fatty Liver Disease Is Associated With Carotid Atherosclerosis: a Case-Control Study. Arterioscler Thromb Vasc Biol 25:1045-1050.

Chen CJ, Chiou H Y, Chiang M H, Lin L J and Tai T Y (1996) Dose-Response Relationship Between Ischemic Heart Disease Mortality and Long-Term Arsenic Exposure. Arterioscler Thromb Vasc Biol 16:504-510.

Chen CJ, Hsueh Y M, Lai M S, Shyu M P, Chen S Y, Wu M M, Kuo T L and Tai T $Y$ (1995) Increased Prevalence of Hypertension and Long-Term Arsenic Exposure. Hypertension 25:53-60.

Chen H, Li S, Liu J, Diwan B A, Barrett J C and Waalkes M P (2004) Chronic Inorganic Arsenic Exposure Induces Hepatic Global and Individual Gene Hypomethylation: Implications for Arsenic Hepatocarcinogenesis. Carcinogenesis 25:1779-1786.

Chen Y, Graziano J H, Parvez F, Liu M, Slavkovich V, Kalra T, Argos M, Islam T, Ahmed A, Rakibuz-Zaman M, Hasan R, Sarwar G, Levy D, van G A and Ahsan H (2011) Arsenic Exposure From Drinking Water and Mortality From Cardiovascular Disease in Bangladesh: Prospective Cohort Study. BMJ 342:d2431.

Concha G, Vogler G, Lezcano D, Nermell B and Vahter M (1998) Exposure to Inorganic Arsenic Metabolites During Early Human Development. Toxicol Sci 44:185-190.

Das S, Santra A, Lahiri S and Guha Mazumder D N (2005) Implications of Oxidative Stress and Hepatic Cytokine (TNF-Alpha and IL-6) Response in the Pathogenesis of Hepatic Collagenesis in Chronic Arsenic Toxicity. Toxicol Appl Pharmacol 204:18-26.

de Boo HA and Harding J E (2006) The Developmental Origins of Adult Disease (Barker) Hypothesis. Aust N Z J Obstet Gynaecol 46:4-14. 
Del Razo LM, Quintanilla-Vega B, Brambila-Colombres E, Calderon-Aranda E S, Manno M and Albores A (2001) Stress Proteins Induced by Arsenic. Toxicol Appl Pharmacol 177:132-148.

Engel RR and Smith A H (1994) Arsenic in Drinking Water and Mortality From Vascular Disease: an Ecologic Analysis in 30 Counties in the United States. Arch Environ Health 49:418-427.

Fry RC, Navasumrit P, Valiathan C, Svensson J P, Hogan B J, Luo M, Bhattacharya S, Kandjanapa K, Soontararuks S, Nookabkaew S, Mahidol C, Ruchirawat M and Samson L D (2007) Activation of Inflammation/NF-KappaB Signaling in Infants Born to Arsenic-Exposed Mothers. PLoS Genet 3:e207.

Gerszten RE, Garcia-Zepeda E A, Lim Y C, Yoshida M, Ding H A, Gimbrone M A, Jr., Luster A D, Luscinskas F W and Rosenzweig A (1999) MCP-1 and IL-8 Trigger Firm Adhesion of Monocytes to Vascular Endothelium Under Flow Conditions. Nature 398:718-723.

Gething MJ and Sambrook J (1992) Protein Folding in the Cell. Nature 355:3345 .

Gluckman PD and Hanson M A (2004) Developmental Origins of Disease Paradigm: a Mechanistic and Evolutionary Perspective. Pediatr Res 56:311-317.

Gorzowski JJ, Eckerley C A, Halgren R G, Mangurten A B and Phillips B (1995) Methylation-Associated Transcriptional Silencing of the Major Histocompatibility Complex-Linked Hsp70 Genes in Mouse Cell Lines. J Biol Chem 270:2694026949.

Gu L, Okada Y, Clinton S K, Gerard C, Sukhova G K, Libby P and Rollins B J (1998) Absence of Monocyte Chemoattractant Protein-1 Reduces Atherosclerosis in Low Density Lipoprotein Receptor-Deficient Mice. Mol Cell 2:275-281.

Guha Mazumder DN (2001) Arsenic and Liver Disease. J Indian Med Assoc 99:311, 314-311, 320.

Han SG, Castranova V and Vallyathan V (2005) Heat Shock Protein 70 As an Indicator of Early Lung Injury Caused by Exposure to Arsenic. Mol Cell Biochem 277:153-164.

Holm PW, Slart R H, Zeebregts C J, Hillebrands J L and Tio R A (2009) Atherosclerotic Plaque Development and Instability: a Dual Role for VEGF. Ann Med 41:257-264.

Hsueh YM, Wu W L, Huang Y L, Chiou H Y, Tseng C H and Chen C J (1998) Low Serum Carotene Level and Increased Risk of Ischemic Heart Disease Related to Long-Term Arsenic Exposure. Atherosclerosis 141:249-257. 
Jin Y, Xi S, Li X, Lu C, Li G, Xu Y, Qu C, Niu Y and Sun G (2006) Arsenic Speciation Transported Through the Placenta From Mother Mice to Their Newborn Pups. Environ Res 101:349-355.

Kato K, Ito H and Okamoto K (1997) Modulation of the Arsenite-Induced Expression of Stress Proteins by Reducing Agents. Cell Stress Chaperones 2:199-209.

Khalil S, Luciano J, Chen W and Liu A Y (2006) Dynamic Regulation and Involvement of the Heat Shock Transcriptional Response in Arsenic Carcinogenesis. J Cell Physiol 207:562-569.

Khan I, Dekou V, Hanson M, Poston L and Taylor P (2004) Predictive Adaptive Responses to Maternal High-Fat Diet Prevent Endothelial Dysfunction but Not Hypertension in Adult Rat Offspring. Circulation 110:1097-1102.

Khan IY, Taylor P D, Dekou V, Seed P T, Lakasing L, Graham D, Dominiczak A F, Hanson M A and Poston L (2003) Gender-Linked Hypertension in Offspring of Lard-Fed Pregnant Rats. Hypertension 41:168-175.

Kiang JG and Tsokos G C (1998) Heat Shock Protein 70 KDa: Molecular Biology, Biochemistry, and Physiology. Pharmacol Ther 80:183-201.

Kleemann R, Zadelaar S and Kooistra T (2008) Cytokines and Atherosclerosis: a Comprehensive Review of Studies in Mice. Cardiovasc Res 79:360-376.

Kobayashi M and Yamamoto M (2005) Molecular Mechanisms Activating the Nrf2-Keap1 Pathway of Antioxidant Gene Regulation. Antioxid Redox Signal 7:385-394.

Koch AE, Polverini P J, Kunkel S L, Harlow L A, DiPietro L A, Elner V M, Elner S $G$ and Strieter R M (1992) Interleukin-8 As a Macrophage-Derived Mediator of Angiogenesis. Science 258:1798-1801.

Kugelmas M, Hill D B, Vivian B, Marsano L and McClain C J (2003) Cytokines and NASH: a Pilot Study of the Effects of Lifestyle Modification and Vitamin E. Hepatology 38:413-419.

Lee PC, Ho I C and Lee T C (2005) Oxidative Stress Mediates Sodium ArseniteInduced Expression of Heme Oxygenase-1, Monocyte Chemoattractant Protein1, and Interleukin-6 in Vascular Smooth Muscle Cells. Toxicol Sci 85:541-550.

Lemaire M, Lemarie C A, Molina M F, Schiffrin E L, Lehoux S and Mann K K (2011) Exposure to Moderate Arsenic Concentrations Increases Atherosclerosis in ApoE-/- Mouse Model. Toxicol Sci. 
Li J, Sherman-Baust C A, Tsai-Turton M, Bristow R E, Roden R B and Morin P J (2009) Claudin-Containing Exosomes in the Peripheral Circulation of Women With Ovarian Cancer. BMC Cancer 9:244.

Li Z and Diehl A M (2003) Innate Immunity in the Liver. Curr Opin Gastroenterology 19:565-571.

Lindgren A, Danielsson B R, Dencker L and Vahter M (1984) Embryotoxicity of Arsenite and Arsenate: Distribution in Pregnant Mice and Monkeys and Effects on Embryonic Cells in Vitro. Acta Pharmacol Toxicol (Copenh) 54:311-320.

Liu J, Kadiiska M B, Liu Y, Lu T, Qu W and Waalkes M P (2001) Stress-Related Gene Expression in Mice Treated With Inorganic Arsenicals. Toxicol Sci 61:314320.

Liu J, Xie Y, Ducharme D M, Shen J, Diwan B A, Merrick B A, Grissom S F, Tucker C J, Paules R S, Tennant R and Waalkes M P (2006) Global Gene Expression Associated With Hepatocarcinogenesis in Adult Male Mice Induced by in Utero Arsenic Exposure. Environ Health Perspect 114:404-411.

Liu J, Xie Y, Ward J M, Diwan B A and Waalkes M P (2004) Toxicogenomic Analysis of Aberrant Gene Expression in Liver Tumors and Nontumorous Livers of Adult Mice Exposed in Utero to Inorganic Arsenic. Toxicol Sci 77:249-257.

Lloyd AR, Oppenheim J J, Kelvin D J and Taub D D (1996) Chemokines Regulate T Cell Adherence to Recombinant Adhesion Molecules and Extracellular Matrix Proteins. J Immunol 156:932-938.

Lu X and Kakkar V (2010) The Role of Heat Shock Protein (HSP) in Atherosclerosis: Pathophysiology and Clinical Opportunities. Curr Med Chem 17:957-973.

Luc G, Bard J M, Juhan-Vague I, Ferrieres J, Evans A, Amouyel P, Arveiler D, Fruchart J C and Ducimetiere P (2003) C-Reactive Protein, Interleukin-6, and Fibrinogen As Predictors of Coronary Heart Disease: the PRIME Study. Arterioscler Thromb Vasc Biol 23:1255-1261.

Mazumder DN (2005) Effect of Chronic Intake of Arsenic-Contaminated Water on Liver. Toxicol Appl Pharmacol 206:169-175.

Mazumder DN, Das G J, Santra A, Pal A, Ghose A and Sarkar S (1998) Chronic Arsenic Toxicity in West Bengal--the Worst Calamity in the World. J Indian Med Assoc 96:4-7, 18.

McNeely SC, Belshoff A C, Taylor B F, Fan T W, McCabe M J, Jr., Pinhas A R and States J C (2008) Sensitivity to Sodium Arsenite in Human Melanoma Cells Depends Upon Susceptibility to Arsenite-Induced Mitotic Arrest. Toxicol Appl Pharmacol 229:252-261. 
Morikawa A, Kato Y, Sugiyama T, Koide N, Kawai M, Fukada M, Yoshida T and Yokochi T (1998) Altered Expression of Constitutive Type and Inducible Type Heat Shock Proteins in Response of D-Galactosamine-Sensitized Mice to Lipopolysaccharide As an Experimental Endotoxic Shock Model. FEMS Immunol Med Microbiol 21:37-45.

Nordstrom DK (2002) Public Health. Worldwide Occurrences of Arsenic in Ground Water. Science 296:2143-2145.

Petrick JS, Blachere F M, Selmin O and Lantz R C (2009) Inorganic Arsenic As a Developmental Toxicant: in Utero Exposure and Alterations in the Developing Rat Lungs. Mol Nutr Food Res 53:583-591.

Ramirez T, Brocher J, Stopper H and Hock R (2008) Sodium Arsenite Modulates Histone Acetylation, Histone Deacetylase Activity and HMGN Protein Dynamic in Human Cells. Chromosoma 117:147-157.

Reichard JF and Puga A (2010) Effects of Arsenic Exposure on DNA Methylation and Epigenetic Gene Regulation. Epigenomics 2:87-104.

Rinaldi Tosi ME, Bocanegra V, Manucha W, Gil L A and Valles P G (2011) The Nrf2-Keap1 Cellular Defense Pathway and Heat Shock Protein 70 (Hsp70) Response. Role in Protection Against Oxidative Stress in Early Neonatal Unilateral Ureteral Obstruction (UUO). Cell Stress Chaperones 16:57-68.

Roberts RA, Ganey P E, Ju C, Kamendulis L M, Rusyn I and Klaunig J E (2007) Role of the Kupffer Cell in Mediating Hepatic Toxicity and Carcinogenesis. Toxicol Sci 96:2-15.

Rosenberg HG (1974) Systemic Arterial Disease and Chronic Arsenicism in Infants. Arch Pathol 97:360-365.

Rosenberg HG (1973) Systemic Arterial Disease With Myocardial Infarction. Report on Two Infants. Circulation 47:270-275.

Santra A, Das G J, De B K, Roy B and Guha Mazumder D N (1999) Hepatic Manifestations in Chronic Arsenic Toxicity. Indian J Gastroenterol 18:152-155.

Santra A, Maiti A, Chowdhury A and Mazumder D N (2000) Oxidative Stress in Liver of Mice Exposed to Arsenic-Contaminated Water. Indian J Gastroenterol 19:112-115.

Schieffer B, Selle T, Hilfiker A, Hilfiker-Kleiner D, Grote K, Tietge U J, Trautwein C, Luchtefeld M, Schmittkamp C, Heeneman S, Daemen M J and Drexler H (2004) Impact of Interleukin-6 on Plaque Development and Morphology in Experimental Atherosclerosis. Circulation 110:3493-3500. 
Schindhelm RK, Dekker J M, Nijpels G, Bouter L M, Stehouwer C D, Heine R J and Diamant M (2007) Alanine Aminotransferase Predicts Coronary Heart Disease Events: a 10-Year Follow-Up of the Hoorn Study. Atherosclerosis 191:391-396.

Simeonova PP, Hulderman T, Harki D and Luster M I (2003) Arsenic Exposure Accelerates Atherogenesis in Apolipoprotein E(-/-) Mice. Environ Health Perspect 111:1744-1748.

Srivastava S, D'Souza S E, Sen U and States J C (2007) In Utero Arsenic Exposure Induces Early Onset of Atherosclerosis in ApoE-/- Mice. Reprod Toxicol 23:449-456.

Srivastava S, Vladykovskaya E N, Haberzettl P, Sithu S D, D'Souza S E and States J C (2009) Arsenic Exacerbates Atherosclerotic Lesion Formation and Inflammation in ApoE-I- Mice. Toxicol Appl Pharmacol 241:90-100.

States JC, Ngalame N.O., Beier J I and Arteel G E (2009a) Indicators of PostNatal Liver Injury Consequent to in Utero Arsenic Exposure. Birth Defects Res Part A 85.

States JC, Srivastava S, Chen Y and Barchowsky A (2009b) Arsenic and Cardiovascular Disease. Toxicol Sci 107:312-323.

Targher G, Bertolini L, Padovani R, Rodella S, Zoppini G, Zenari L, Cigolini M, Falezza G and Arcaro G (2006) Relations Between Carotid Artery Wall

Thickness and Liver Histology in Subjects With Nonalcoholic Fatty Liver Disease. Diabetes Care 29:1325-1330.

Targher G, Bertolini L, Padovani R, Zenari L, Zoppini G and Falezza G (2004) Relation of Nonalcoholic Hepatic Steatosis to Early Carotid Atherosclerosis in Healthy Men: Role of Visceral Fat Accumulation. Diabetes Care 27:2498-2500.

Tokar EJ, Diwan B A, Ward J M, Delker D A and Waalkes M P (2011) Carcinogenic Effects of "Whole-Life" Exposure to Inorganic Arsenic in CD1 Mice. Toxicol Sci 119:73-83.

Tseng CH (2008) Cardiovascular Disease in Arsenic-Exposed Subjects Living in the Arseniasis-Hyperendemic Areas in Taiwan. Atherosclerosis 199:12-18.

Vega VL, Rodriguez-Silva M, Frey T, Gehrmann M, Diaz J C, Steinem C, Multhoff G, Arispe N and De M A (2008) Hsp70 Translocates into the Plasma Membrane After Stress and Is Released into the Extracellular Environment in a Membrane-Associated Form That Activates Macrophages. J Immunol 180:42994307.

Waalkes MP, Liu J, Chen H, Xie Y, Achanzar W E, Zhou Y S, Cheng M L and Diwan B A (2004) Estrogen Signaling in Livers of Male Mice With Hepatocellular 
Carcinoma Induced by Exposure to Arsenic in Utero. J Natl Cancer Inst 96:466474.

Waalkes MP, Liu J, Ward J M and Diwan B A (2006) Enhanced Urinary Bladder and Liver Carcinogenesis in Male CD1 Mice Exposed to Transplacental Inorganic Arsenic and Postnatal Diethylstilbestrol or Tamoxifen. Toxicol Appl Pharmacol 215:295-305.

Waalkes MP, Ward J M, Liu J and Diwan B A (2003) Transplacental Carcinogenicity of Inorganic Arsenic in the Drinking Water: Induction of Hepatic, Ovarian, Pulmonary, and Adrenal Tumors in Mice. Toxicol Appl Pharmacol 186:7-17.

Wang CH, Hsiao C K, Chen C L, Hsu L I, Chiou H Y, Chen S Y, Hsueh Y M, Wu $M M$ and Chen C J (2007) A Review of the Epidemiologic Literature on the Role of Environmental Arsenic Exposure and Cardiovascular Diseases. Toxicol Appl Pharmacol 222:315-326.

Wang $\mathrm{CH}$, Jeng J S, Yip P K, Chen C L, Hsu L I, Hsueh Y M, Chiou H Y, Wu M $M$ and Chen C J (2002) Biological Gradient Between Long-Term Arsenic Exposure and Carotid Atherosclerosis. Circulation 105:1804-1809.

Wijeweera JB, Gandolfi A J, Parrish A and Lantz R C (2001) Sodium Arsenite Enhances AP-1 and NFkappaB DNA Binding and Induces Stress Protein Expression in Precision-Cut Rat Lung Slices. Toxicol Sci 61:283-294.

Wright BH, Corton J M, El-Nahas A M, Wood R F and Pockley A G (2000) Elevated Levels of Circulating Heat Shock Protein 70 (Hsp70) in Peripheral and Renal Vascular Disease. Heart Vessels 15:18-22.

Wu J, Liu J, Waalkes M P, Cheng M L, Li L, Li C X and Yang Q (2008) High Dietary Fat Exacerbates Arsenic-Induced Liver Fibrosis in Mice. Exp Biol Med (Maywood) 233:377-384

Wu MM, Chiou H Y, Ho I C, Chen C J and Lee T C (2003) Gene Expression of Inflammatory Molecules in Circulating Lymphocytes From Arsenic-Exposed Human Subjects. Environ Health Perspect 111:1429-1438.

Xie Y, Liu J, Benbrahim-Tallaa L, Ward J M, Logsdon D, Diwan B A and Waalkes M P (2007) Aberrant DNA Methylation and Gene Expression in Livers of Newborn Mice Transplacentally Exposed to a Hepatocarcinogenic Dose of Inorganic Arsenic. Toxicology 236:7-15.

Yue TL, Mckenna P J, Gu J L and Feuerstein G Z (1993) Interleukin-8 Is Chemotactic for Vascular Smooth Muscle Cells. Eur J Pharmacol 240:81-84.

Zhou X, Sun H, Ellen T P, Chen H and Costa M (2008) Arsenite Alters Global Histone H3 Methylation. Carcinogenesis 29:1831-1836. 
Zhu J, Quyyumi A A, Wu H, Csako G, Rott D, Zalles-Ganley A, Ogunmakinwa J, Halcox J and Epstein S E (2003) Increased Serum Levels of Heat Shock Protein 70 Are Associated With Low Risk of Coronary Artery Disease. Arterioscler

Thromb Vasc Biol 23:1055-1059 


\section{APPENDIX}

List of Abbreviations

AALAC

ALP

ALT

ANOVA

ApoE $^{-/}$mice

AST

bp

CAE

$\mathrm{CO}_{2}$

CpG

CVD

DNA

DTT

EGTA

$E C L$

EDTA

EPA

GD
Association for Assessment of Laboratory Animal care

Alanine phosphatase

Alanine amino transferase

Analysis of Variance

Apolipoprotein E knockout mice

Aspartate amino transferase

base pair

Chloroacetae esterase

carbon dioxide

Cytosine guanine linear dinucleotide

Cardiovascular disease

Deoxyribonucleic acid

Dithiothreitol

Ethylene glycol tetraacetic acid

Enhanced chemiluminescence

Ethylene diamine tetraacetic acid

Environmental Protection Agency

Gestation day 


$\begin{array}{ll}\mathrm{HCL} & \text { Hydrogen chloride } \\ \mathrm{H} / \mathrm{E} & \text { Hematoxylin/Eosin } \\ \mathrm{HRP} & \text { Horse radish peroxidase } \\ \mathrm{Hsc70} & \text { Heat shock cognate } 70 \\ \mathrm{Hsf1} & \text { Heat shock factor } 1 \\ \mathrm{Hsp70} & \text { Heat shock protein } 70 \\ \mathrm{HSPA} & \text { Heat shock protein family A } \\ \mathrm{ICP}-\mathrm{MS} & \text { Inductively-coupled plasma mass spectrometry } \\ \mathrm{IL}-6 & \text { Interleukin-6 } \\ \mathrm{IP} & \text { Intraperitoneal } \\ \mathrm{IVC} & \text { Inferior vena cava } \\ \mathrm{KC} & \text { Kupffer cell } \\ \mathrm{LPS} & \text { Lipopolysaccharide } \\ \mathrm{NPC} & \text { Non parenchymal cell } \\ \mathrm{MCL} & \text { Sodium orthovanadate } \\ \mathrm{MCP}-1 & \text { Maximum contaminant limit } \\ \mathrm{mRNA} & \text { Monocyte chemoattractant protein-1 } \\ \mathrm{miRNA} & \text { messenger ribonucleic acid } \\ \mathrm{NaAsO} & \text { Micro ribonucleic acid } \\ \mathrm{NaCl} & \mathrm{NaF} \\ \mathrm{NAFLD} & \text { Sodium arsenite } \\ \mathrm{Na} & \end{array}$


Nrf2

OCT

PBS

PC

PCR

PMSF

RIPA

RNA

SAM

SC

SEC

SDS

SDS-PAGE

TE

TNF- $\alpha$

US

USEPA

VEGF

WHO
Nuclear factor-2 erythroid related factor-2

Optimal cutting temperature

Phosphate buffered saline

Parenchymal cell

Polymerase chain reaction

Phenylmethylsulphonylfluoride

Radioimmunoprecipitation assay

Ribonucleic acid

S-adenosyl methionine

Stellate cell

Sinusoidal endothelial cell

Sodium dodecyl sulfate

Sodium dodecyl sulfate - polyacrylamide gel electrophoresis

Tris- ethylene diamine tetraacetic acid

Tumor necrosis factor alpha

United States

United States Environmental Protection Agency

Vascular endothelial growth factor

World Health Organization 


\section{CURRICULUM VITAE}

\section{Ntube Nini Olive Ngalame, M.S.}

\section{OFFICE ADDRESS}

University of Louisville School of Medicine Department of Pharmacology \& Toxicology 505 South Hancock Street Clinical and Translational Research Building, Room 352C Louisville, KY 40202

Work: (502) 8522405 nnngal01@gwise.louisville.edu

\section{HOME ADDRESS}

6401 Fern Valley Ct., Ap't 4 Louisville, KY 40219

${ }^{*}$ Cell: (502) 6449387

*preferred contact number

\section{EDUCATION}

08/2009 - Present University of Louisville, Louisville, KY

$\mathrm{Ph}$.D. Candidate, anticipated graduation date: August 2011

Discipline of study: Pharmacology \& Toxicology

08/2007 - 08/2009 University of Louisville, Louisville, KY

Masters of Science, August 2009

Discipline of study: Pharmacology \& Toxicology

09/2003 - 12/2004 Lund University, Lund, Sweden

Masters of Science, December 2004

Discipline of study: Bio- and Food Technology

09/1999 - 12/2002 University of Buea, Buea, Cameroon

Bachelor of Science, December 2002 
Major: Microbiology, Minor: Medical Laboratory Technology

\section{SCIENTIFIC/PROFESSIONAL EXPERIENCE}

2007-Present

2007

2005

2002-2003
Graduate Research Assistant, Dept. of Pharmacolgy \&Toxicology, University of Louisville, Louisville, KY.

Research Intern, Department of Biochemistry and Molecular Biology, University of Louisville, Louisville, KY Laboratory of Prough A. Russell, Ph.D.

Research Assistant, Department of Biotechnology, Lund University, Lund, Sweden.

High School Biology Teacher, Frank Harcourt Bilingual High School, Kumba, Cameroon.

\section{PROFESSIONAL SOCIETIES}

- National Society of Toxicology

- Society of Toxicology - Metals Specialty Section

- Society of Toxicology - Ohio Valley Chapter

- Teratology Society

- Golden Key International Honor Society

HONORS \& AWARDS

$12 / 2010$ Society of Toxicology student travel award to attend the $50^{\text {th }}$ annual SOT meeting.

$03 / 2010$ Teratology Society student travel award to attend the $50^{\text {th }}$ annual Teratology Society meeting.

02/2009 Center for Genetics and Molecular Medicine (CGeMM) travel award to attend annual SOT meeting.

01/2009 University of Louisville Graduate Student Council travel award to attend annual SOT meeting.

01/2009 University of Louisville School of Medicine Research Committee travel award to attend annual SOT meeting.

11/2008 Best Poster Presentation Masters Graduate Student Award, Ohio Valley Society of Toxicology.

10/2008 First Place Masters Graduate Student Award, Research Louisville 
08/07-06/09 University of Louisville Integrated Programs in Biomedical Sciences Predoctoral Fellowship Award.

12/2002 Graduation with Distinction, University of Buea, Buea, Cameroon

12/2001 Dean's List, Faculty of Science, University of Buea, Buea, Cameroon

\section{PUBLICATIONS}

\section{Manuscripts in preparation}

1) Ntube N.O. Ngalame, Marilyn E. Feil, Andrew F. Micciche, and J. Christopher States. Delayed temporal increase of hepatic Hsp70 in ApoE ${ }^{-1-}$ mice after prenatal arsenic exposure. (To be submitted to Journal of Toxicological Science)

2) Ntube N.O. Ngalame, Juliane Arteel, Gavin Arteel, and J. Christopher States. Prenatal arsenic exposure induces subtle hepatic damage and systemic inflammation associated with accelerated atherosclerosis in $\mathrm{ApoE}^{-1}$ mice (To be submitted to Journal of Toxicological Science)

3) Ntube N.O. Ngalame, Srivastava Sanjay, and J. Christopher States. Prenatal As exposure at low exposure levels increases atherosclerotic lesion formation and plasma inflammatory cytokines/chemokines related to cardiovascular disease. (To be submitted to Environmental Health Perspectives)

\section{ABSTRACTS}

\section{Published}

1) Ngalame NN, Arteel JI, Arteel GE, States J. Transplacental exposure to arsenic induces hepatic changes in ApoE - / - mice. Abstract 2099, The Toxicologist, Volume 108, Number 1, March 2009.

2) States JC, Ngalame NO, Beier JI, Arteel GE. Indicators of post-natal liver injury consequent to prenatal arsenic exposure. Birth Defects Research Part A 85: 436 (2009)

3) States JC, Singh A, Knudsen T, Rouchka E, Ko MS, Piao Y, Ngalame NO, Arteel J, Arteel G, Srivastava S. Transplacental Arsenic Exposure Induced Changes In Liver Programming Associated With Accelerated Atherosclerosis. Abstract 1430. The Toxicologist, Volume 114, Number S-1, March 2010

4) Ngalame NNO, Beier JL, Arteel GE, Srivastava S, States JC. Prenatal arsenic exposure induces subtle hepatic damage and systemic inflammation associated with accelerated atherosclerosis in $\mathrm{ApoE}^{-1-}$ mice. Birth Defects Res Part A - 88:379 (2010) 
5) Ngalame NN, Feil ME, Micciche AF, States J. Delayed temporal increase of hepatic $\mathrm{Hsp} 70$ in $\mathrm{ApoE}^{-1-}$ mice with accelerated atherosclerosis induced by prenatal arsenic exposure. Abstract 2199, The Toxicologist, Volume 120, Number S-2, March 2011

6) Ngalame N. O., Srivastava S., and States J.C. (2011) Dose response effects of prenatal arsenic exposure on atherosclerotic lesion formation and inflammation in ApoE ${ }^{-\gamma}$. Birth Defects Research Part A,91 (5) 358

\section{Local/Regional meeting proceedings}

1) Ngalame N.O., Arteel G.E., Arteel J.I., and States J.C. Transplacental Exposure to Arsenic Induces Hepatic Changes in $\mathrm{ApoE}^{-1-}$ Mice. Research Louisville, 2008.

2) Ngalame N.O., Arteel G.E., Arteel J.I., and States J.C. Transplacental Exposure to Arsenic Induces Hepatic Changes in ApoE ${ }^{-/-}$Mice. Society of Toxicology (Ohio Valley Affiliates),2008.

3) Ngalame N.O., Arteel G.E., Arteel J.I., and States J.C. Transplacental Exposure to Arsenic Induces Hepatic Changes in $\mathrm{ApoE}^{-/-}$Mice. University of Louisville Graduate Research Symposium 2009

4) Ngalame N. O., Feil M. E., Micciche A. F., and States J. C. Delayed temporal increase of hepatic $\mathrm{Hsp} 70$ in $\mathrm{ApoE}^{-/-}$mice with accelerated atherosclerosis induced by prenatal arsenic exposure. Society of Toxicology (Ohio Valley Affiliates), 2010.

5) Ngalame N. O., Feil M. E., Micciche A. F., and States J. C. Delayed temporal increase of hepatic $\mathrm{Hsp} 70$ in $\mathrm{ApoE}^{-/ .}$mice with accelerated atherosclerosis induced by prenatal arsenic exposure. Research Louisville, 2010.

6) Ngalame N. O., Feil M. E., Micciche A. F., and States J. C. Delayed temporal increase of hepatic $\mathrm{Hsp} 70$ in $\mathrm{ApoE}^{-/-}$mice with accelerated atherosclerosis induced by prenatal arsenic exposure. $6^{\text {th }}$ Conference on Metal Toxicity and Carcinogenesis, 2010.

\section{Presentations/Seminars}

1) Ngalame N. O., Feil M. E., Micciche A. F., and States J. C. Delayed temporal increase of hepatic $\mathrm{Hsp} 70$ in $\mathrm{ApoE}^{-1}$ mice with accelerated atherosclerosis induced by prenatal arsenic exposure. NIEH Core Centers Annual Meeting, 2010. 